Fall 1923

\title{
1923 Cedrus Yearbook
}

\section{Cedarville College}

Follow this and additional works at: https://digitalcommons.cedarville.edu/yearbooks

Part of the Higher Education Commons, Organizational Communication Commons, and the Public Relations and Advertising Commons

\section{Recommended Citation}

Cedarville College, "1923 Cedrus Yearbook" (1923). Yearbooks. 89.

https://digitalcommons.cedarville.edu/yearbooks/89

This Book is brought to you for free and open access by DigitalCommons@Cedarville, a service of the Centennial Library. It has been accepted for inclusion in Yearbooks by an authorized administrator of DigitalCommons@Cedarville. For more information, please contact digitalcommons@cedarville.edu. 


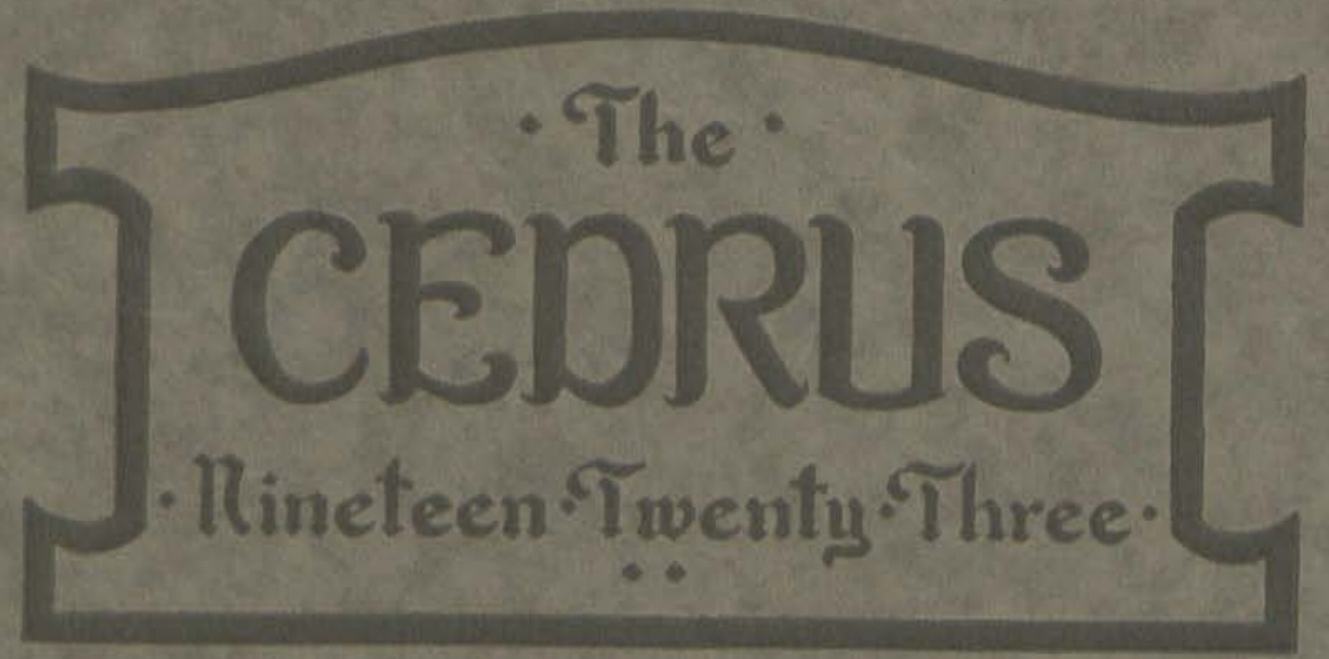




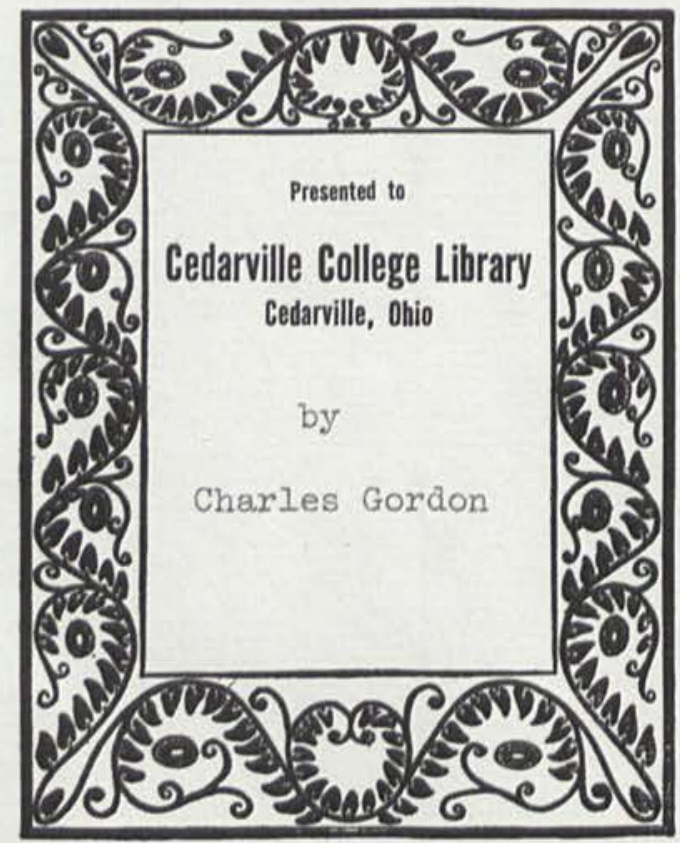





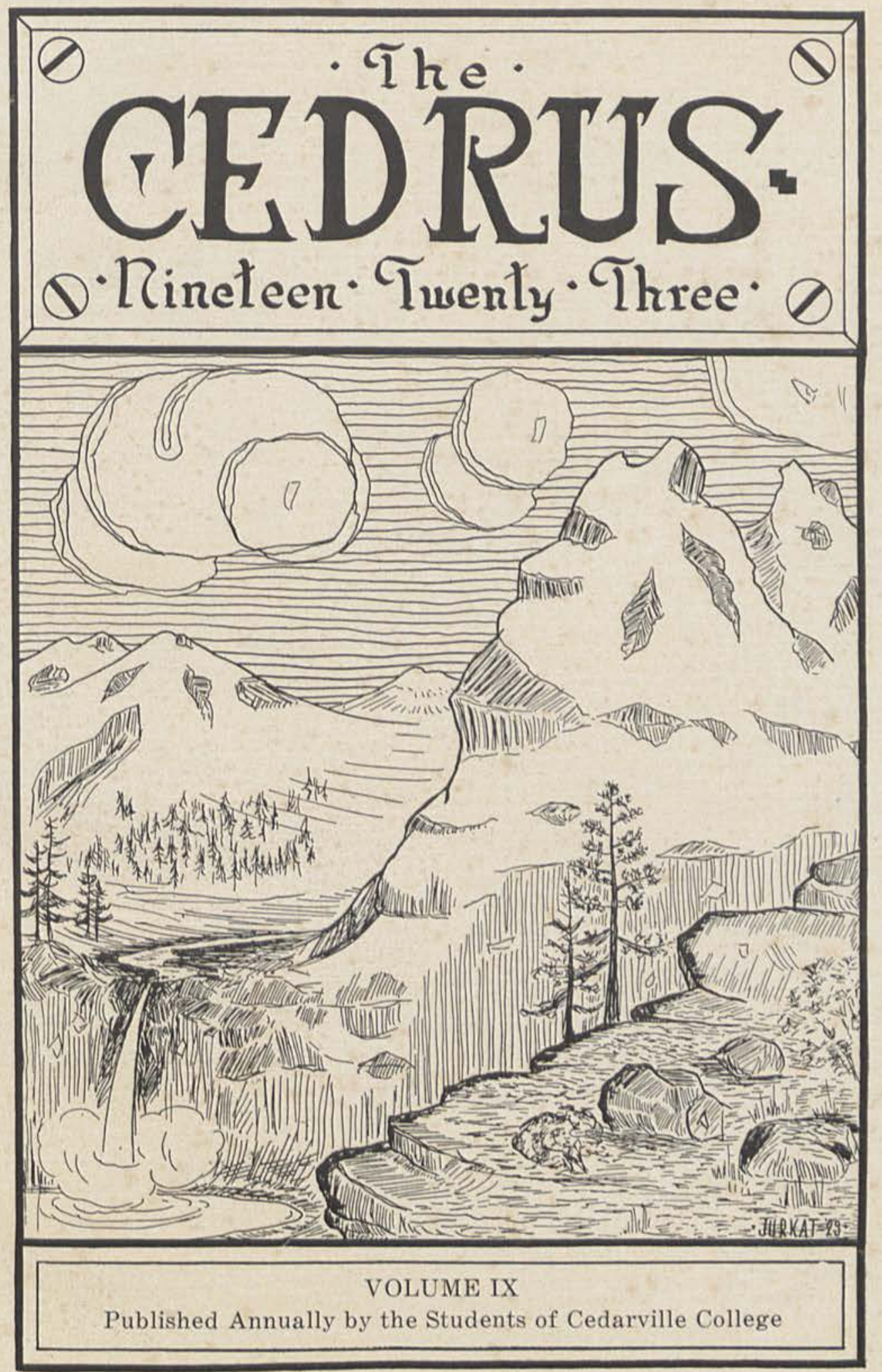




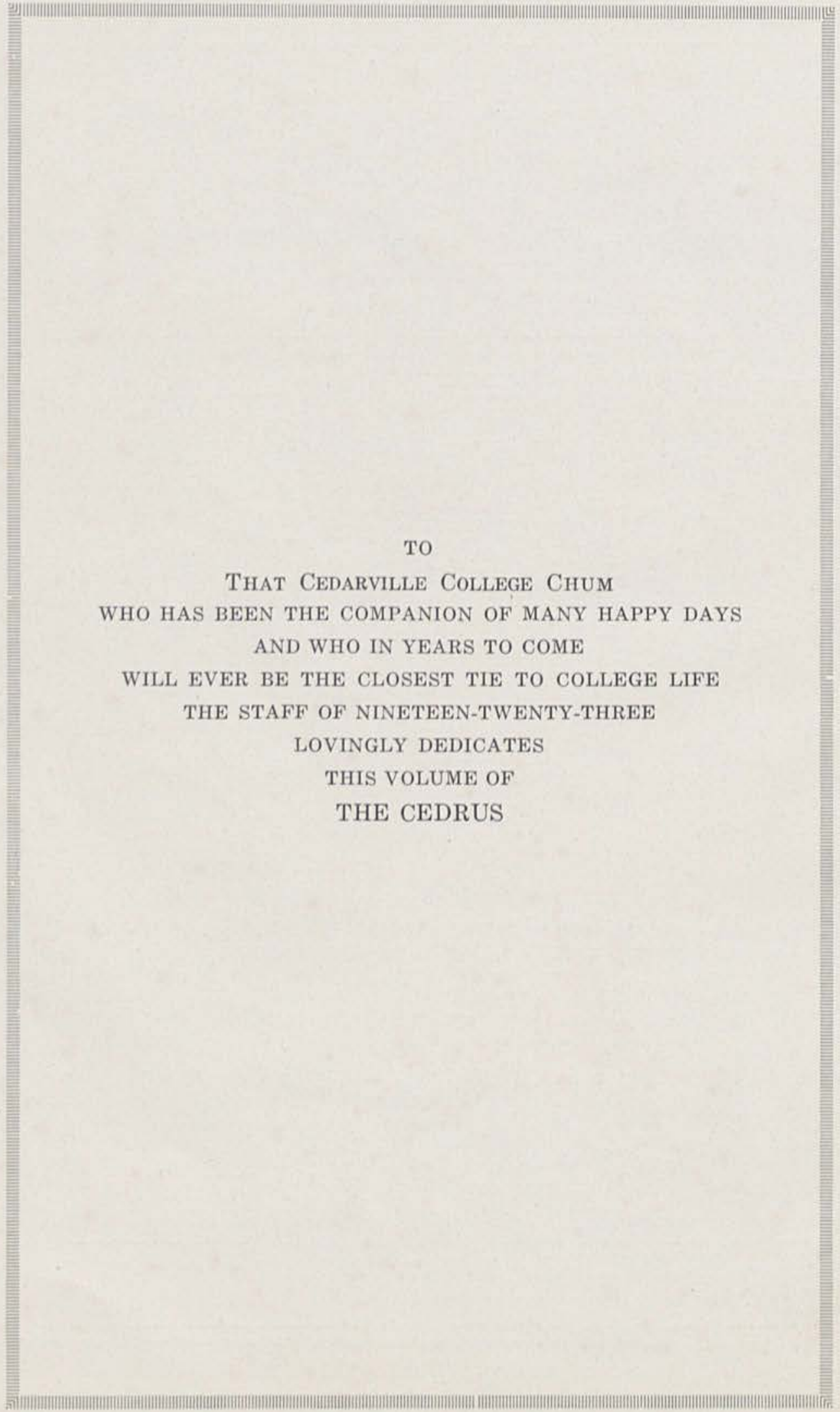




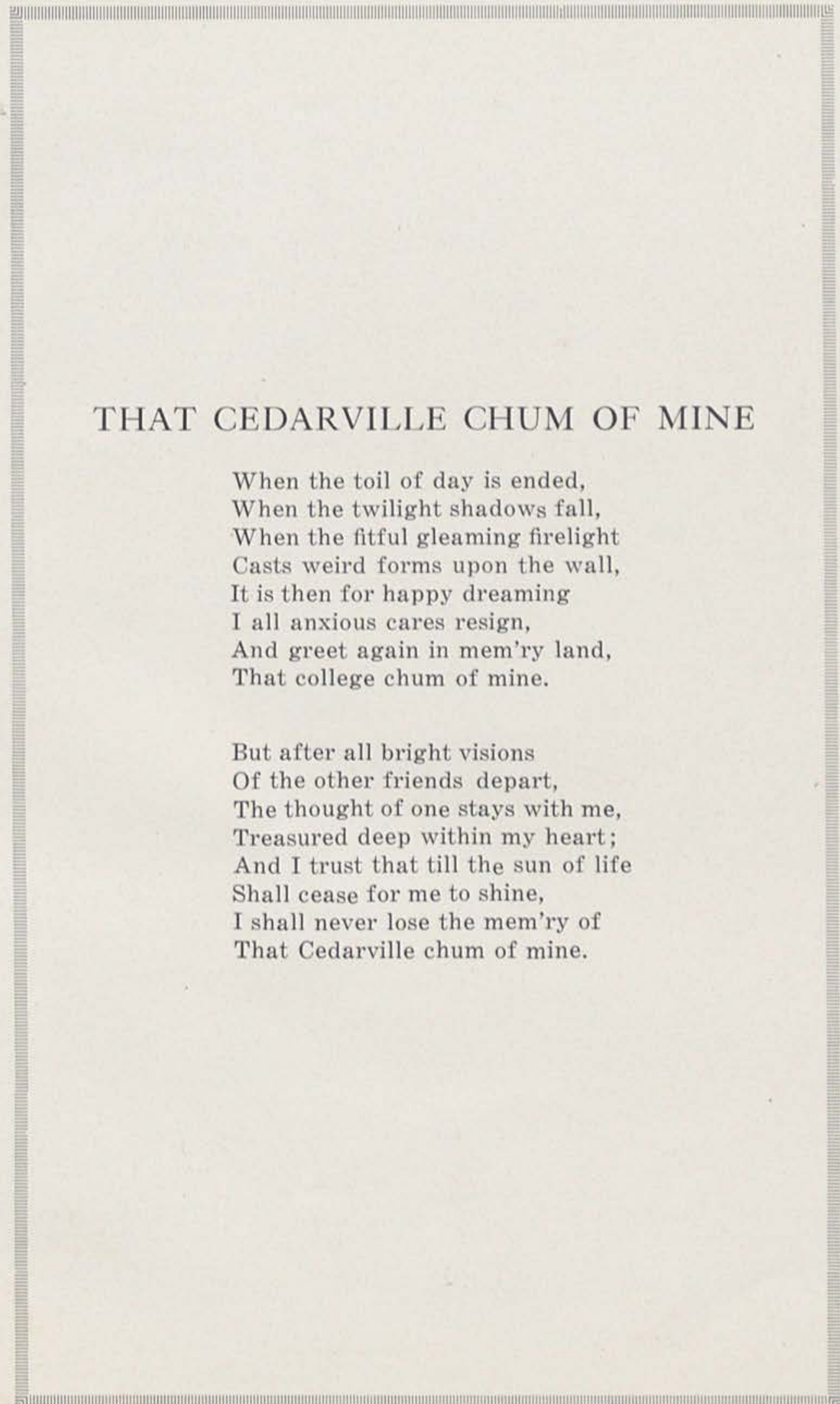




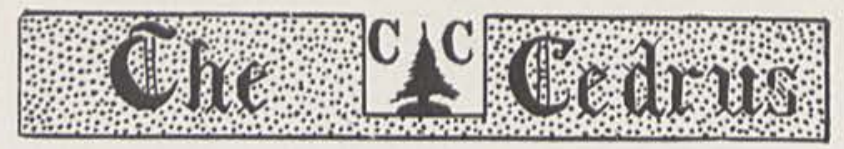

BOOKI - THE COLLEGE

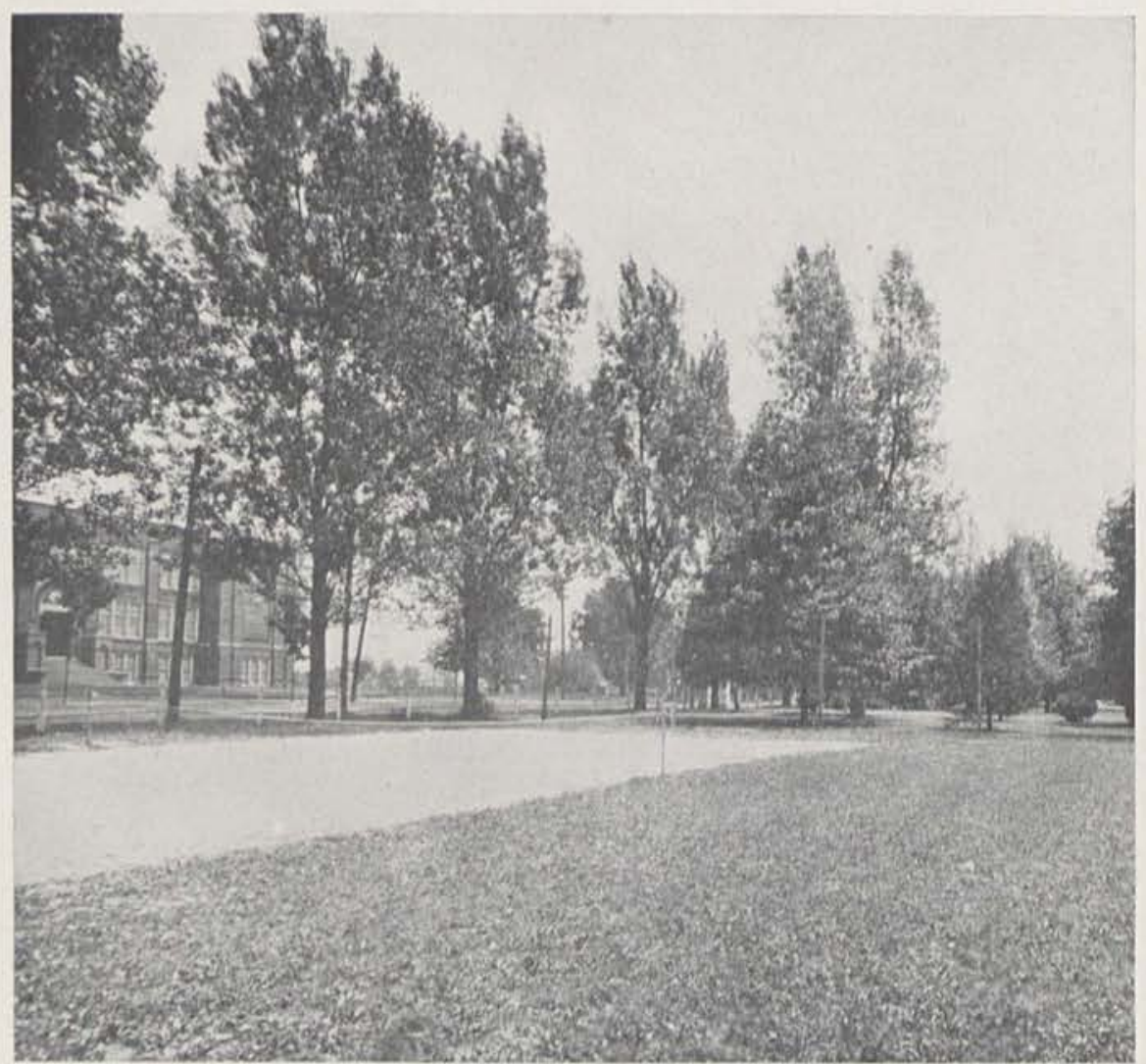



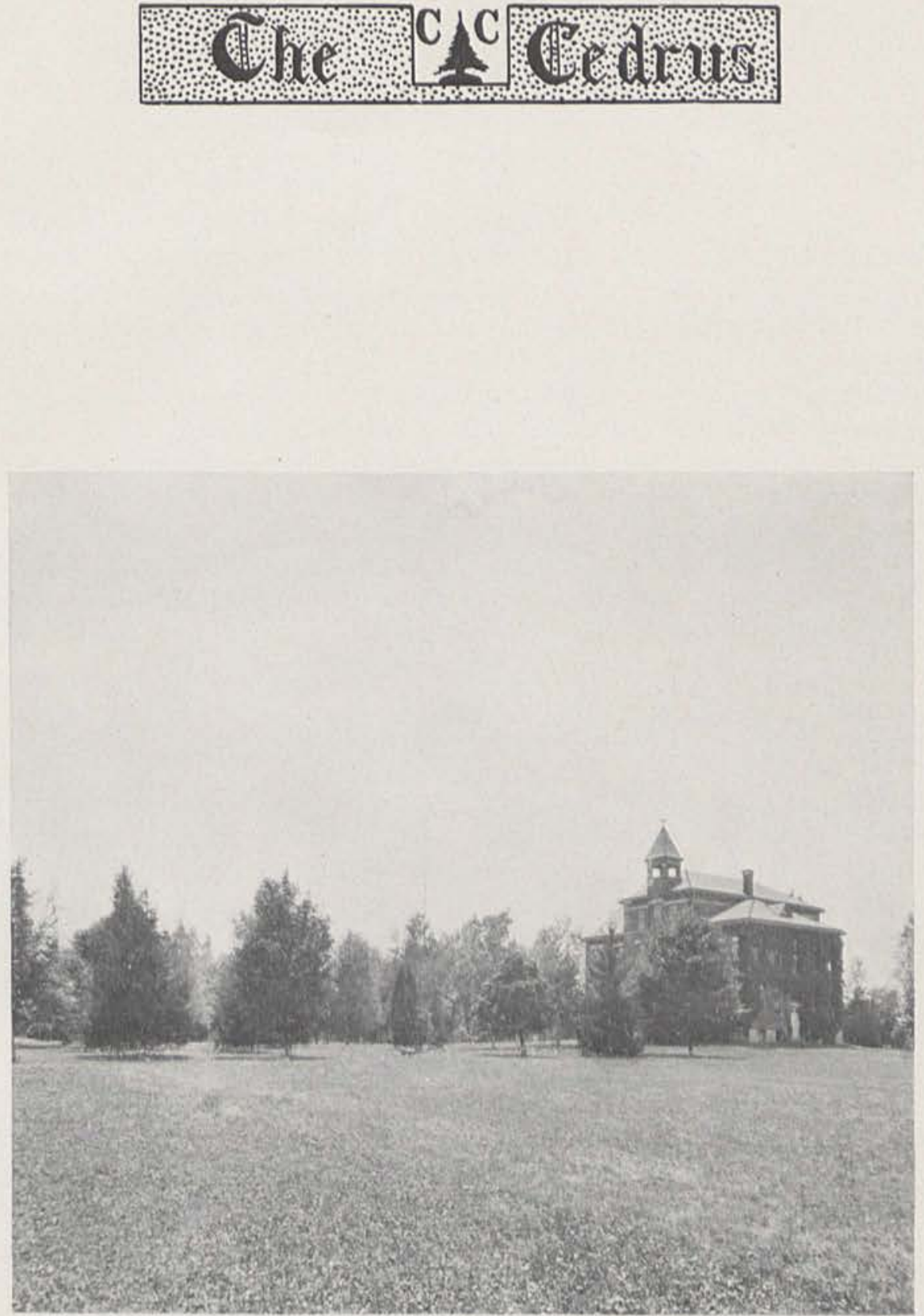


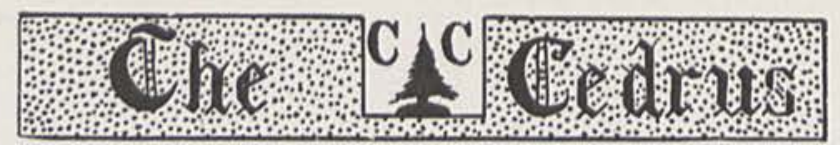

\section{THE COMING CEDARVILLE COLLEGE}

Cedarville College has an ambitious future. Its ambition is worthy of your support. The plan is to have within a few years a standard Christian college. That means an endowment of at least $\$ 300,000$, or $\$ 170,000$ more than Cedarville now has. There will be twelve instead of seven regular collegiate professors beside the president. A girls' and a boys' dormitory, and a gymnasium; or three buildings in addition to the present buildings, to cost at least $\$ 160,000$, will have to be erected. A total sum of $\$ 330,000$ must be raised to meet the requirements of a standard college. A standard college for Cedarville means that Cedarville College will be admitted into full membership in the Ohio Association of Colleges, the American Association, and the North Central Association.

The boys and girls of this community deserve as good collegiate advantages and opportunities as the youth of any other community in the world. Cedarville College has done enough for the people of this community to become the recipient of every dollar which every respectable citizen can give to increase the endowment. Every citizen having the welfare of this community at heart can advance its interests in the highest and truest sense by contributing annually and liberally to the endowment fund of Cedarville College. Cedarville College is now a community college. Work and give to make it the equal, at least, of any other reputable Christian college in America. Give yearly as much as you can spare to Cedarville College. Take an annuity at from 5 to 7 per cent, according to your age and tax free and absolutely safe, in Cedarville College. Remember Cedarville College in your will. Get your wealthy friends to give. The supreme need of the college is endowment and buildings. The last drive in 1921 for funds did not nearly reach the need. Every friend of the college must rise and rise NOW to meet the needs of Cedarville College. This means the alumni, former and present students, patrons, the church, and the community in and around Cedarville. Resolved now that from this time on, you will be one to contribute yearly all that you can and that you will also do all you can to enlist the help of others, until Cedarville College shall become a standard college and its permanence and worth shall be assured.

W. R. MCChesNeY. 

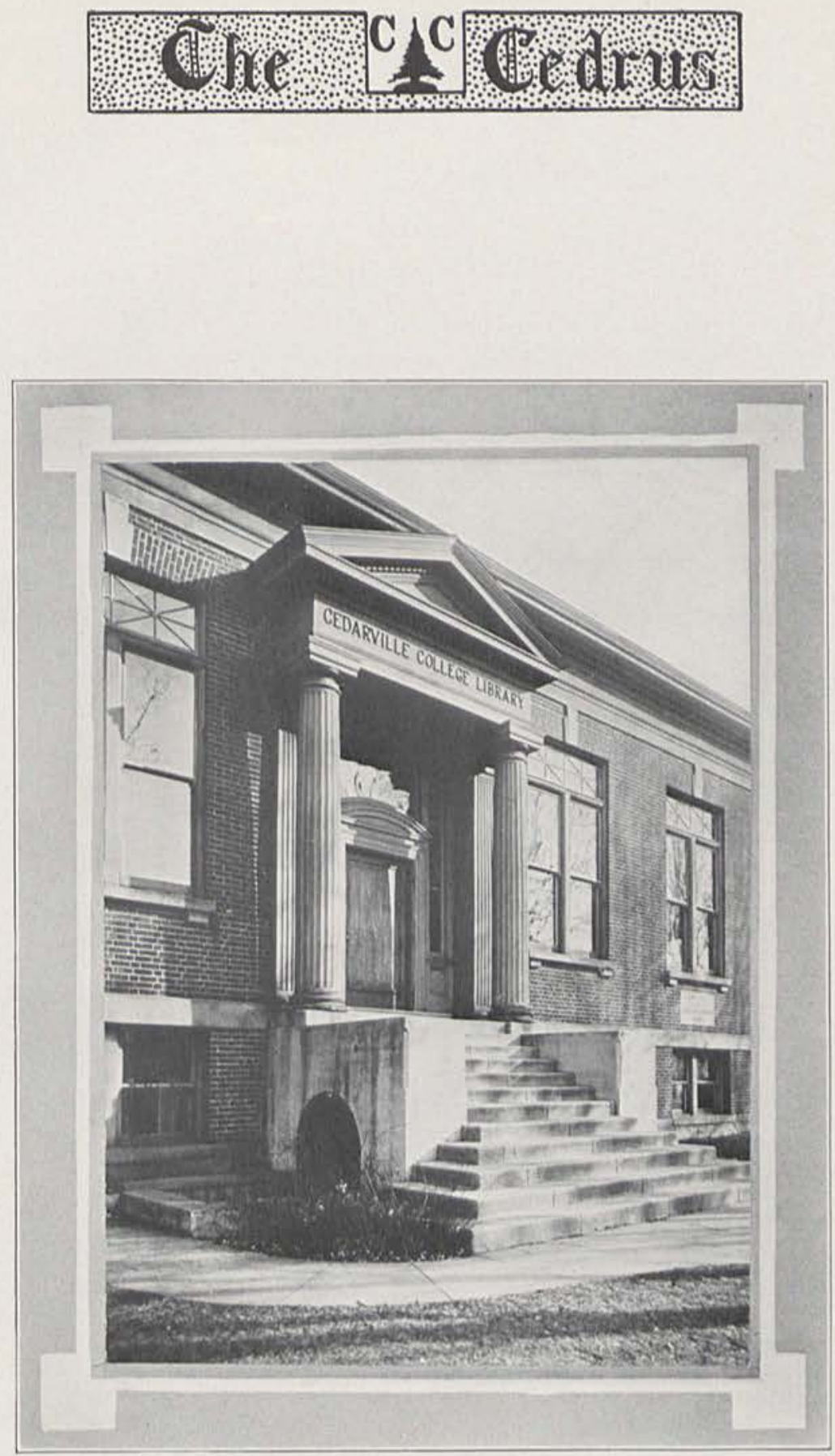

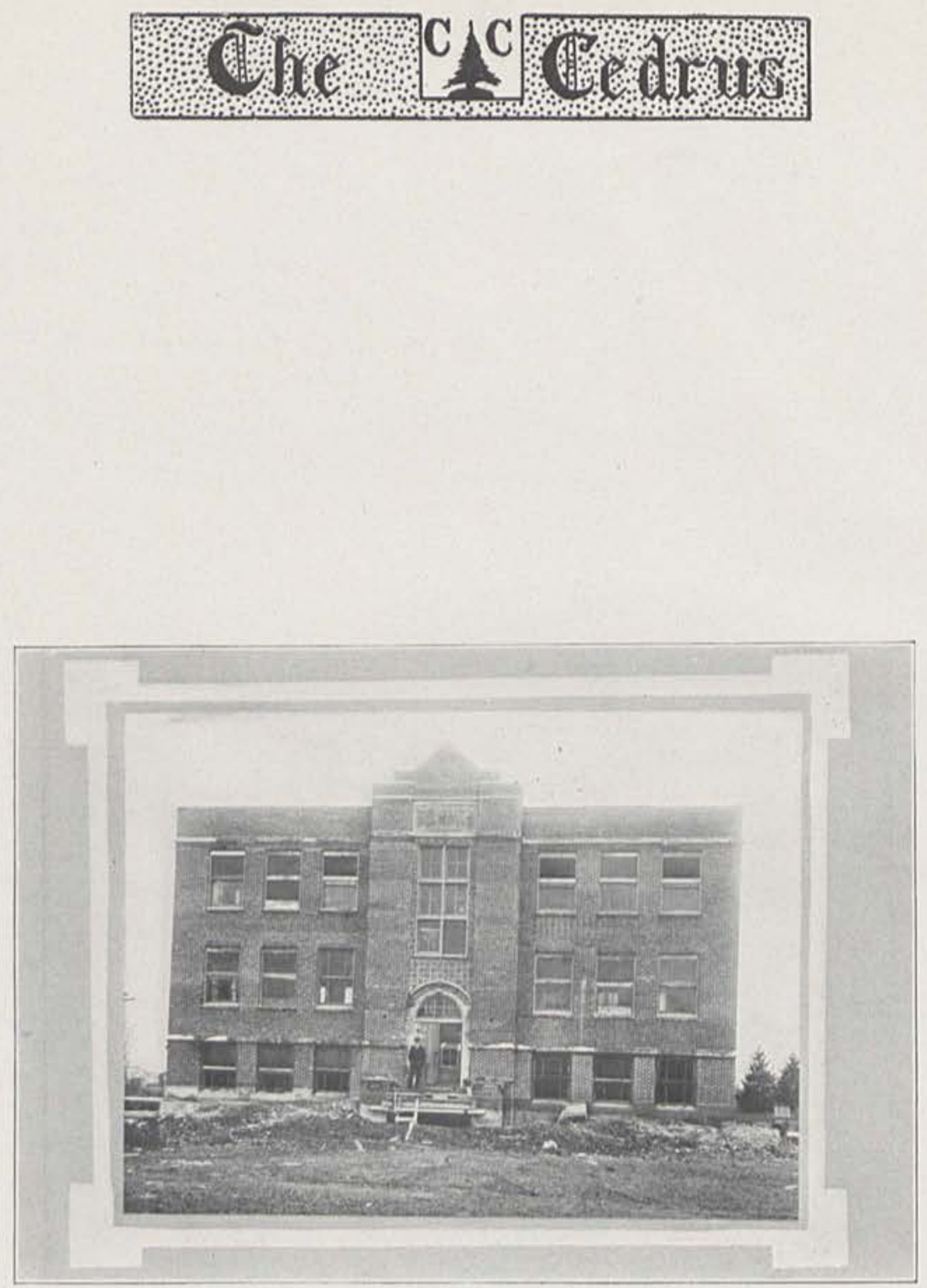

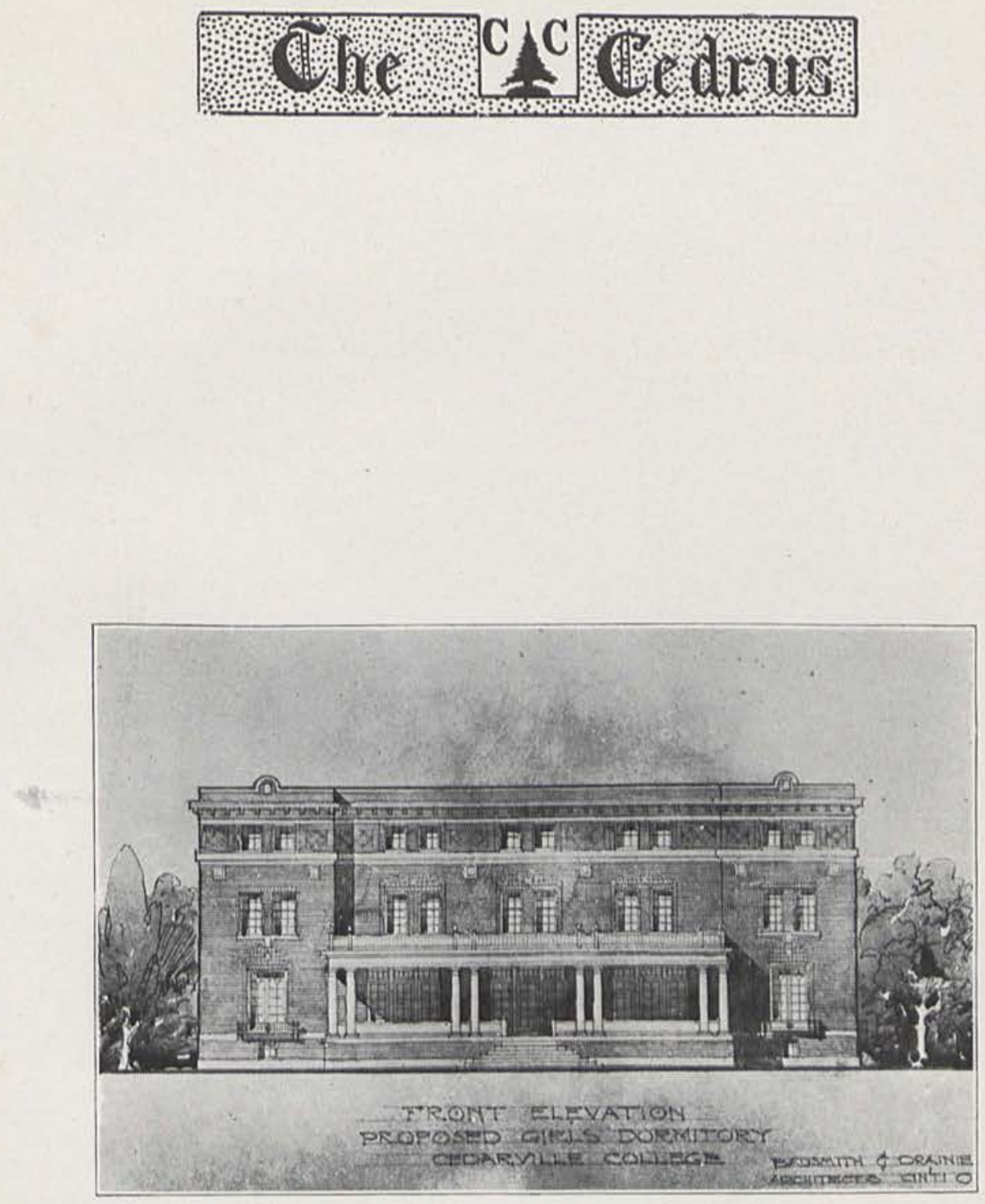

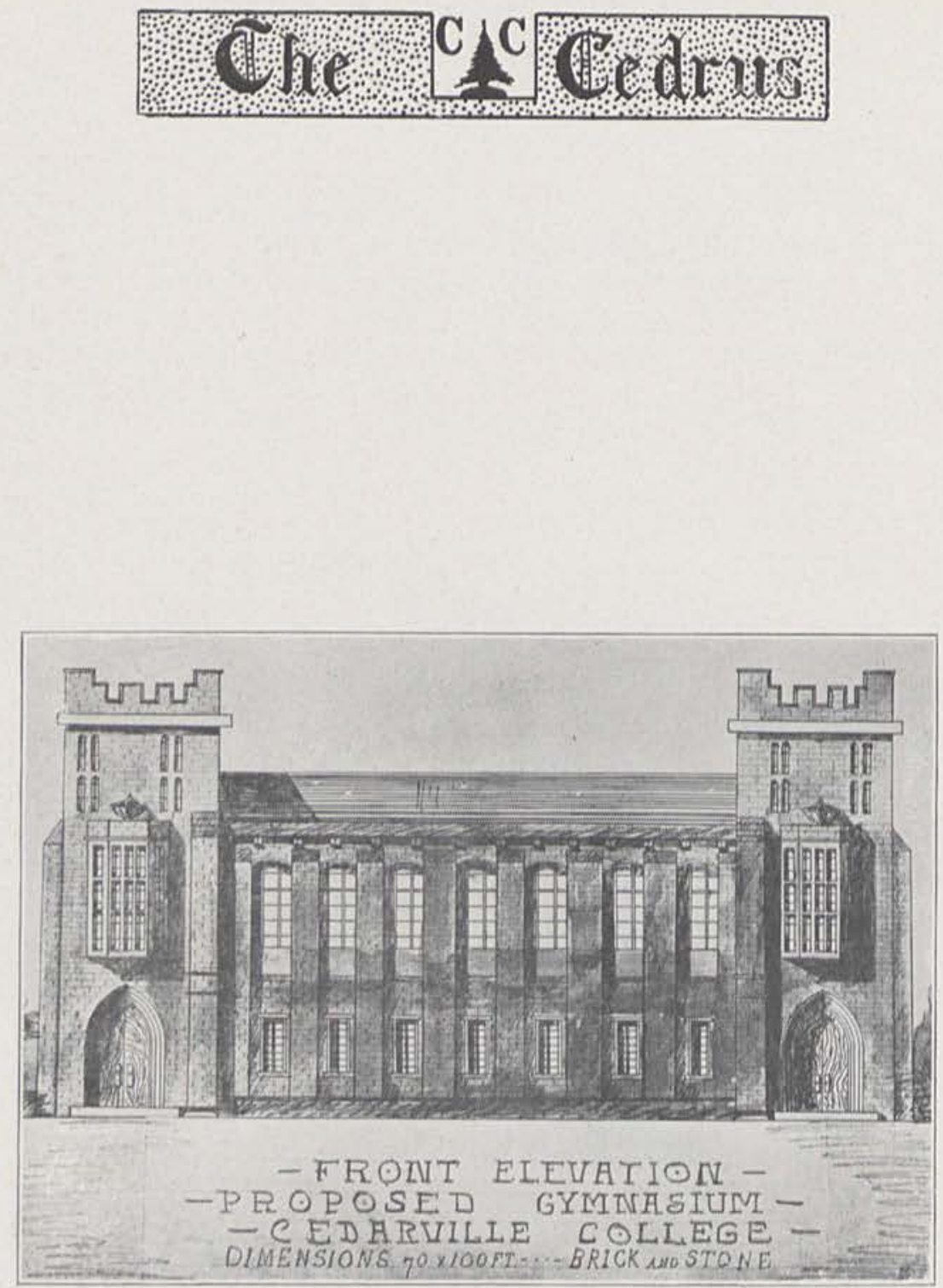

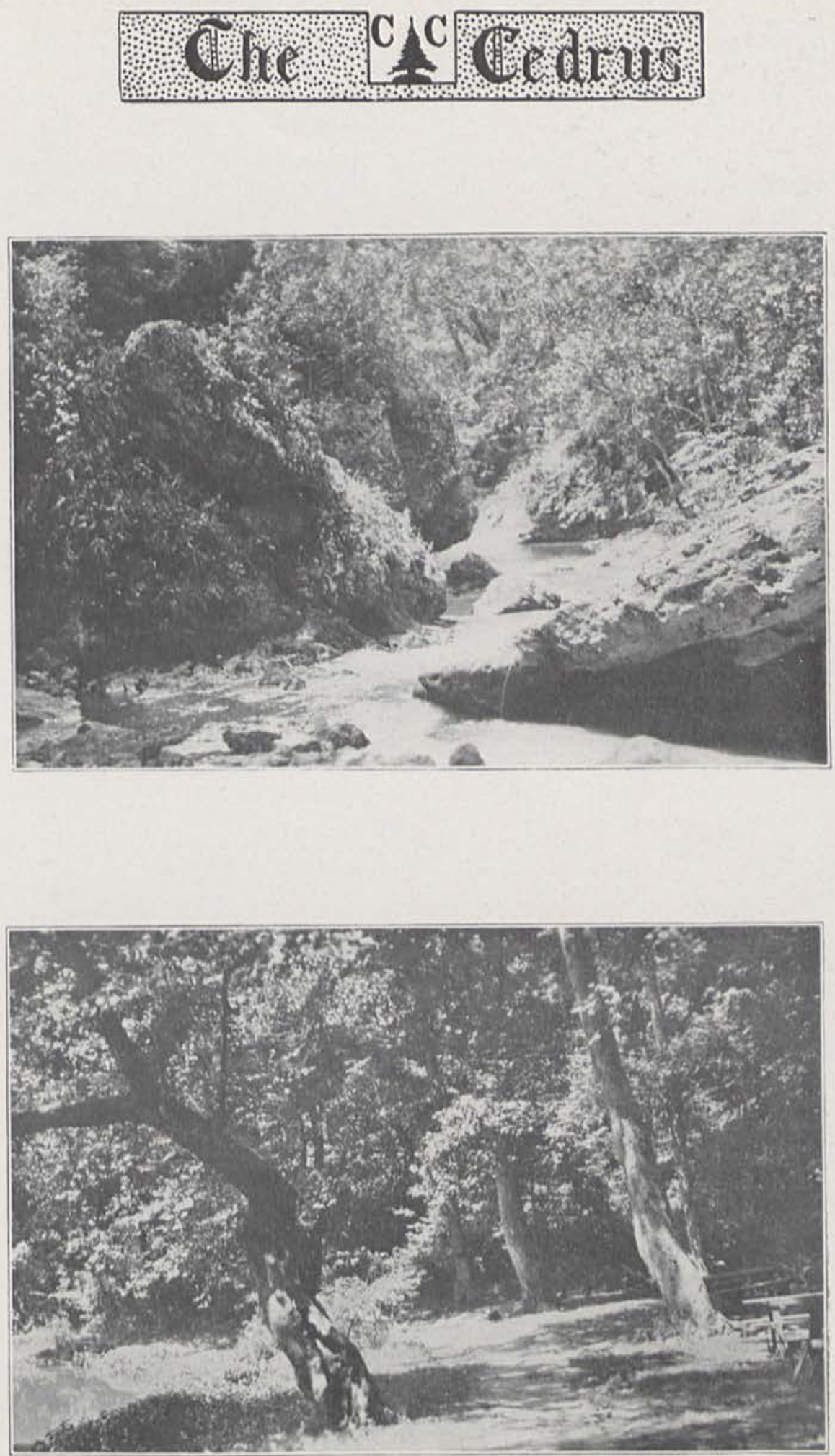

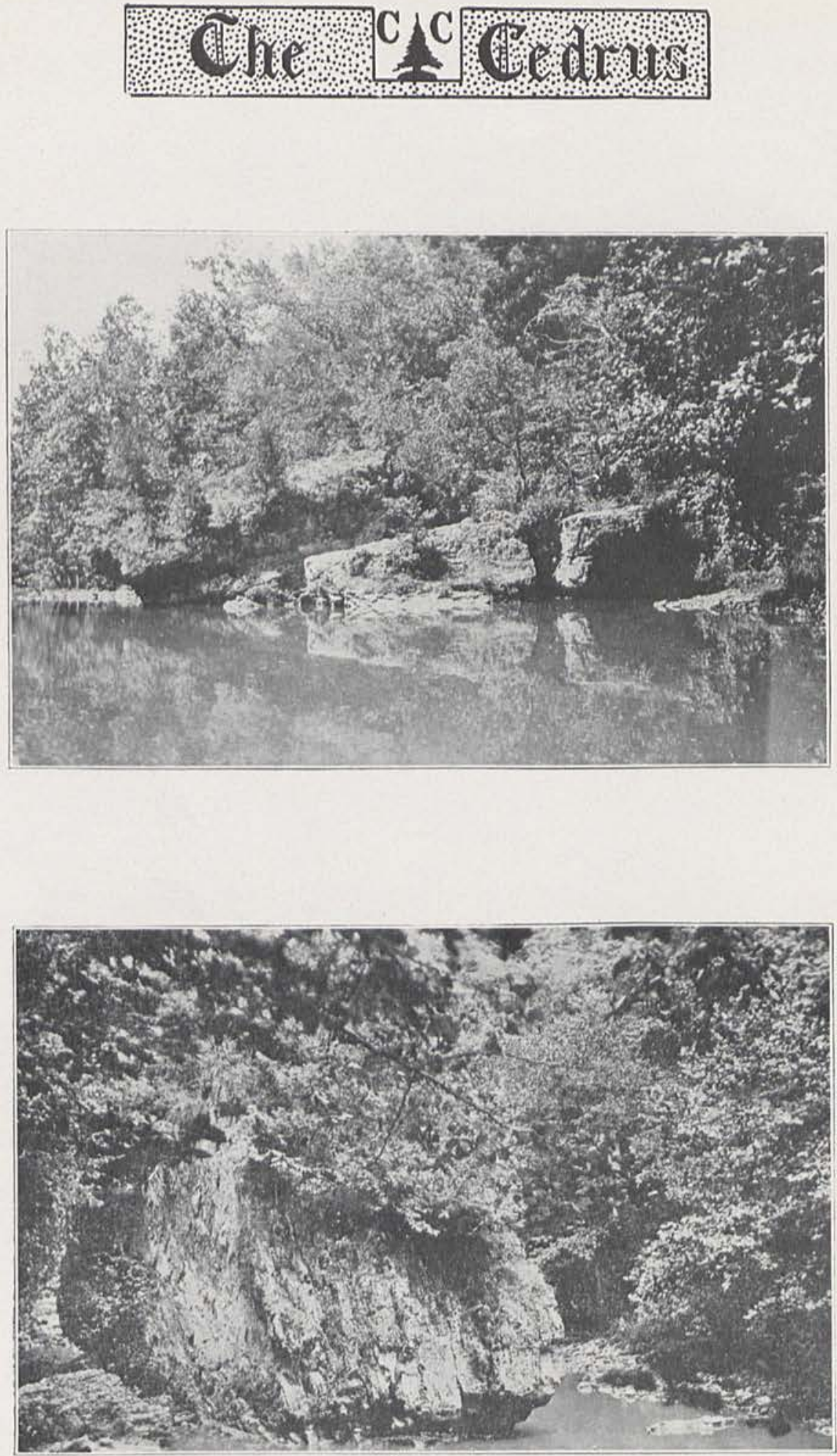


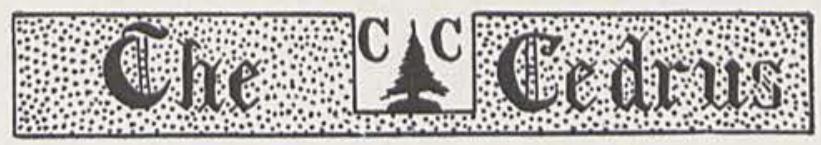

BOOK II - - THE FACULTY

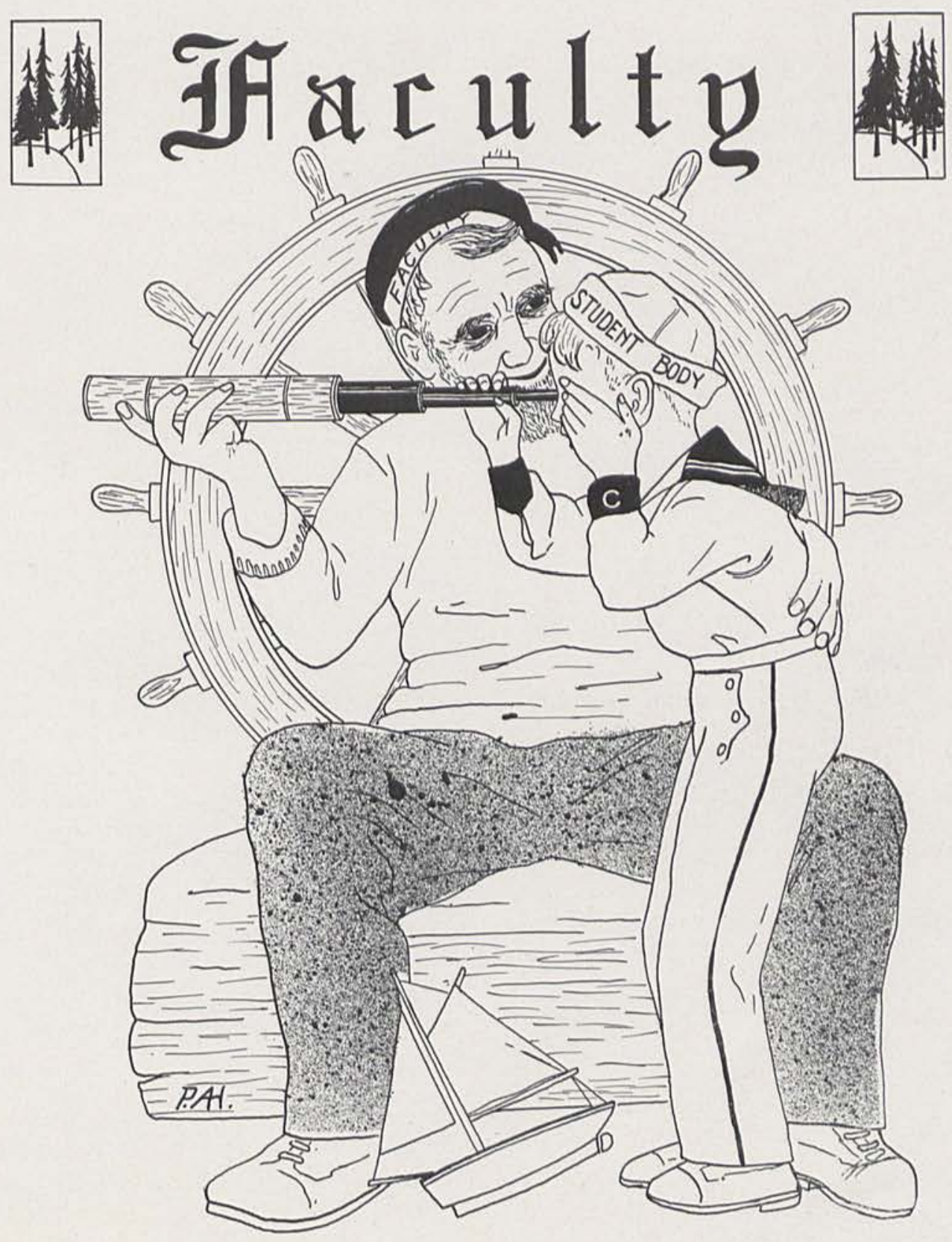




\section{OUR FACULTY}

In our utilitarian age things are judged by their practical value. Men ask of everything, "What is its use?" Nothing is held to be without criticism, neither the law because of its authority, nor religion because of its sacredness. Every relationship in life has also been questioned and is asked to show the reason for its existence.

On the whole it is a good spirit, though it can be abused and carried to an absurd extreme. When we judge a thing by its usefulness we must not have a narrow view of what utility is. Usefulness to man is not confined to mere material values. The things which cannot be bought cannot be sold, and the keenest valuer would be puzzled to put a price on some of these unmarketable wares.

One of the priceless possessions to us as students is the spirit of fellowship and helpfulness which is manifested by our splendid faculty. Youth is the formative period of life and the friendships and ideals of our professors will go with us through our lives. The guidance and companionship of these faithful ones who watch over us, guiding stars in our college careers, will be invaluable as we look back over our Memory Book of old Cedarville College.

We cannot pay a tribute high enough to this band of noble men and women presided over by our beloved president, Dr. McChesney. Their office in their chosen profession is as high as that of the poet Wordsworth, when he said:

"I wish to be considered as a teacher to console the afflicted, to add sunshine to daylight by making the happy, happier; to teach the young and gracious of every age to see, to think and feel, and therefors to become more actively and securely virtuous."

RUTH Mc. 

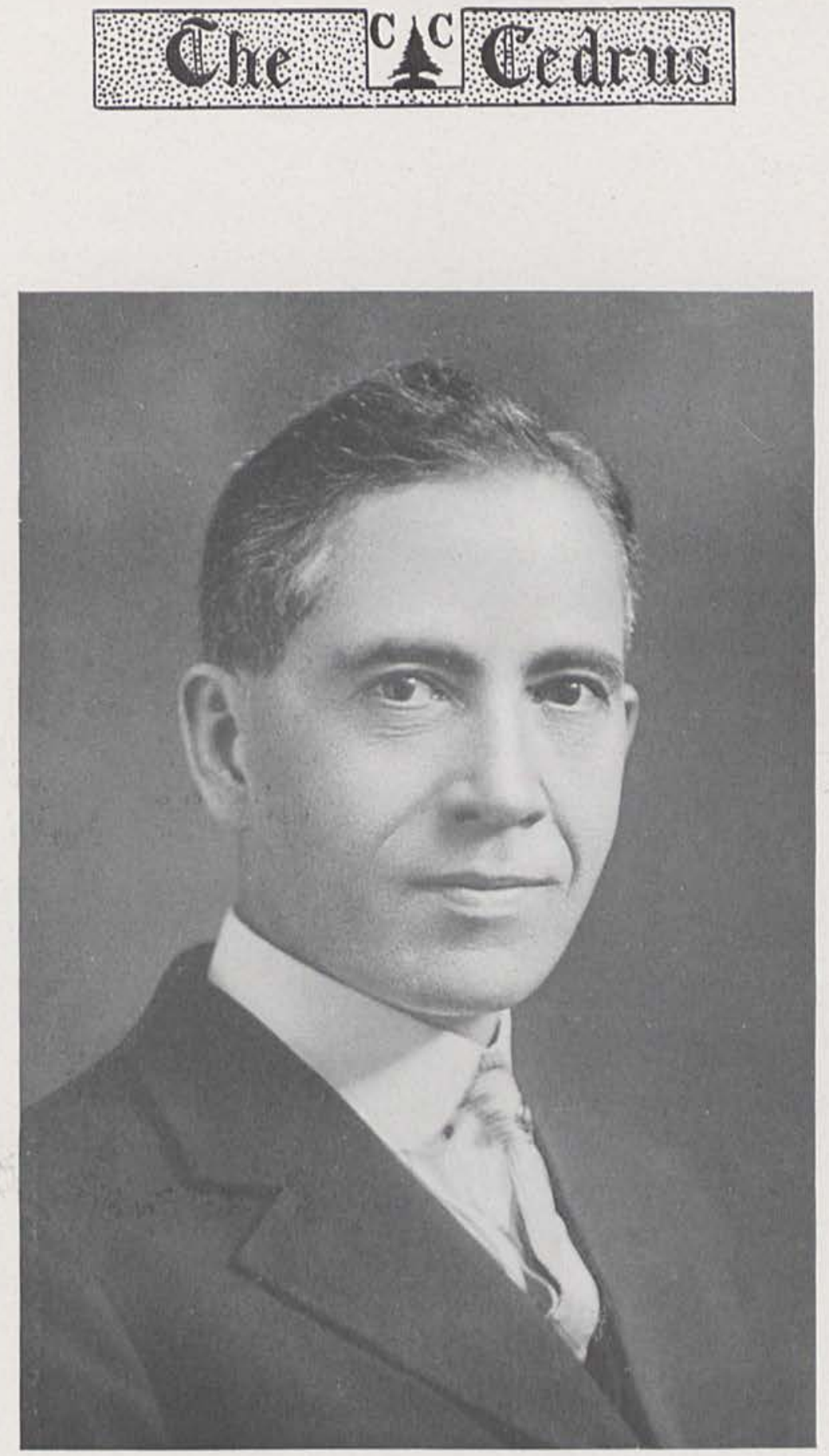

W. Renwick McChesney, Ph. D., D. D. President 


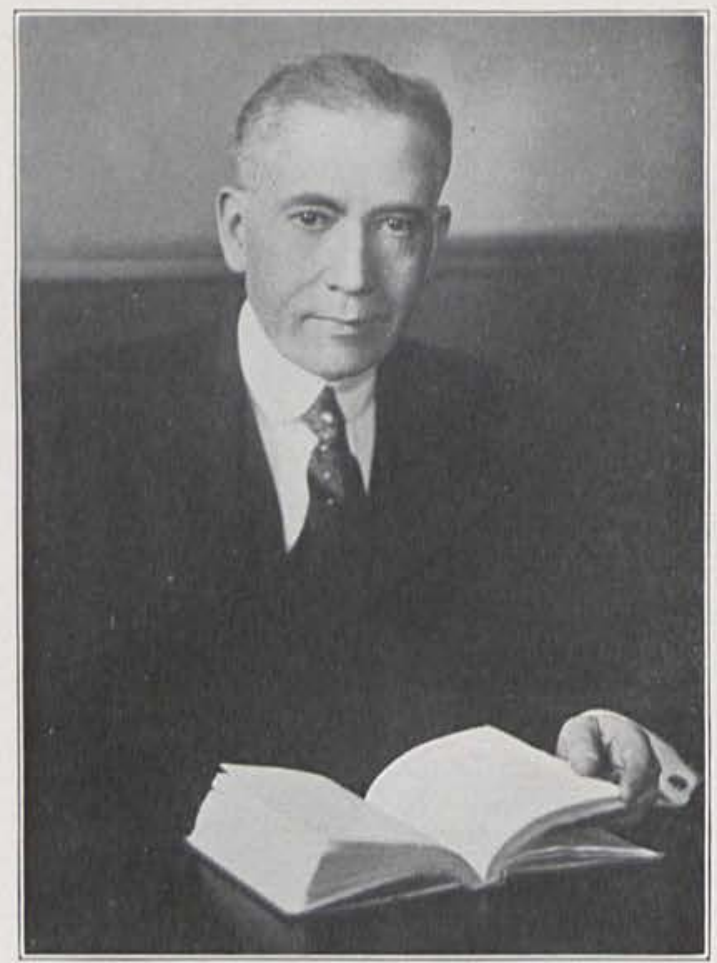
W. RenWick McChesney President

Professor of Psychology, Oratory, Greek

A. B., Franklin College 1892

A. M., Franklin College 1894

Ph. D., Franklin College 1906

D. D., Tarkio College 1915

B. E. RoBISON

Dean and Registrar

Professor of Economics and Sociology

A. B., University of Chicago 1904

B. D., University of Chicago 1906

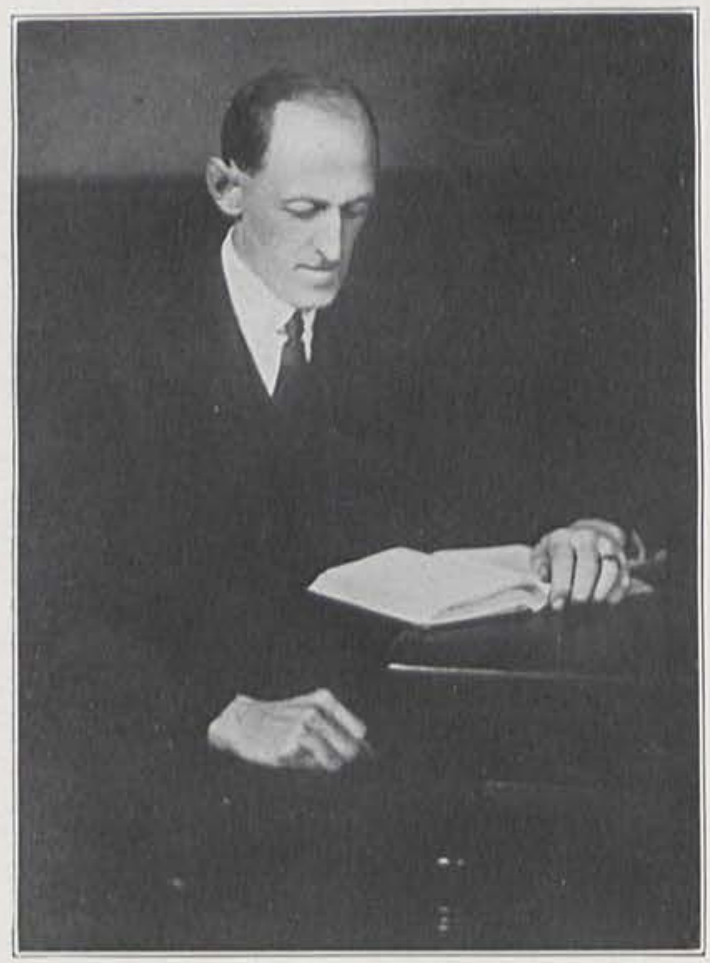




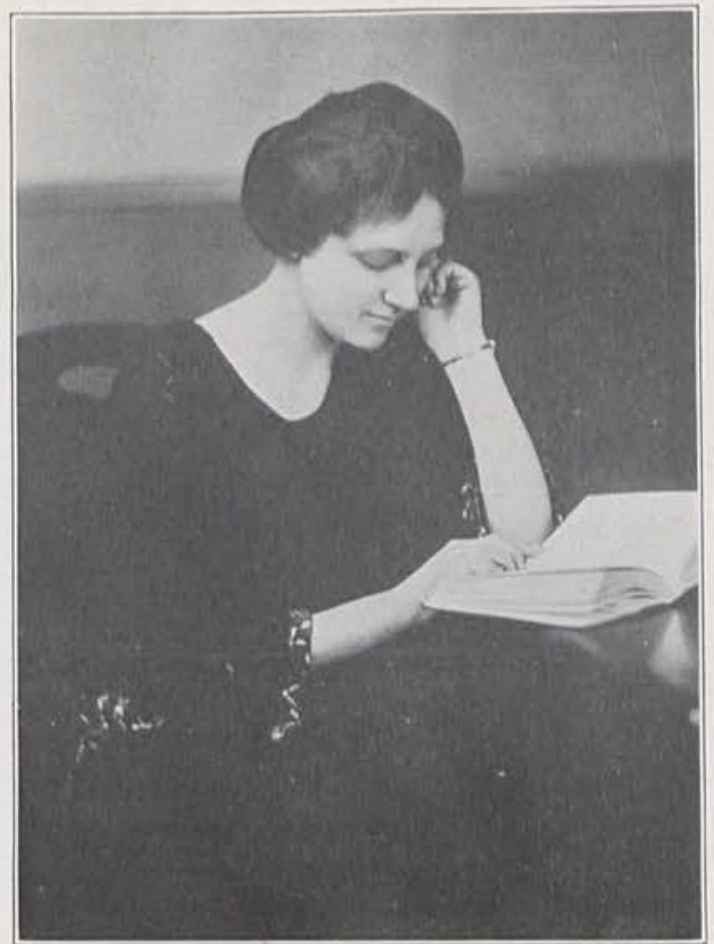

Ethel Blanche Brand

Secretary of Faculty

Professor of English and French

A. B., Indiana University 1919

FrANK ALBERT JURKaT

Treasurer

Professor of Modern Languages,

Hebrew and History

A. B., Franklin College 1895

A. M., Franklin College 1898

LL. D., Franklin College 1917

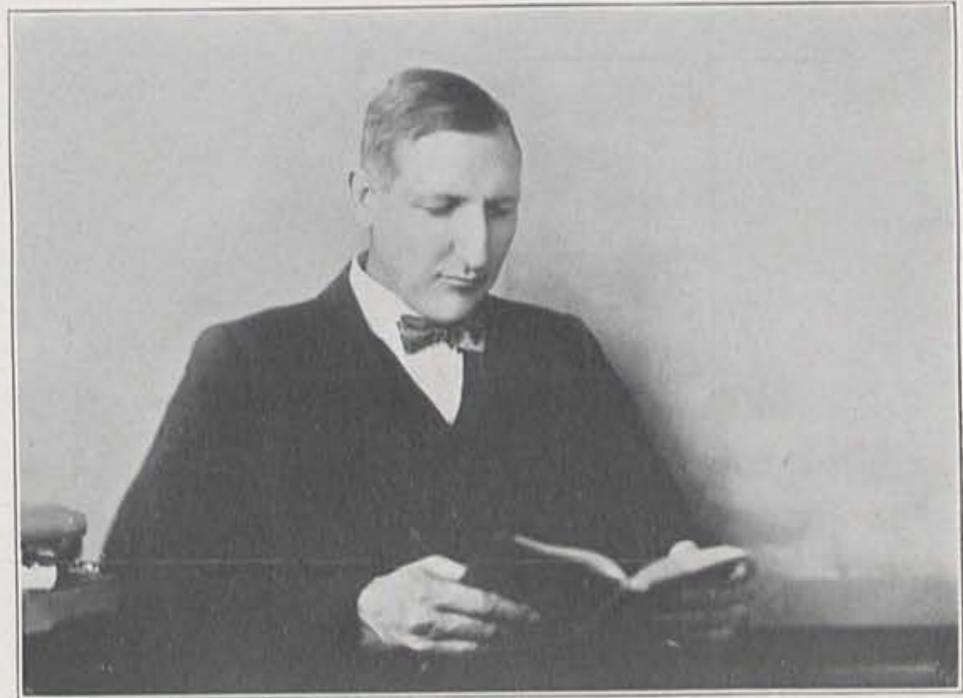




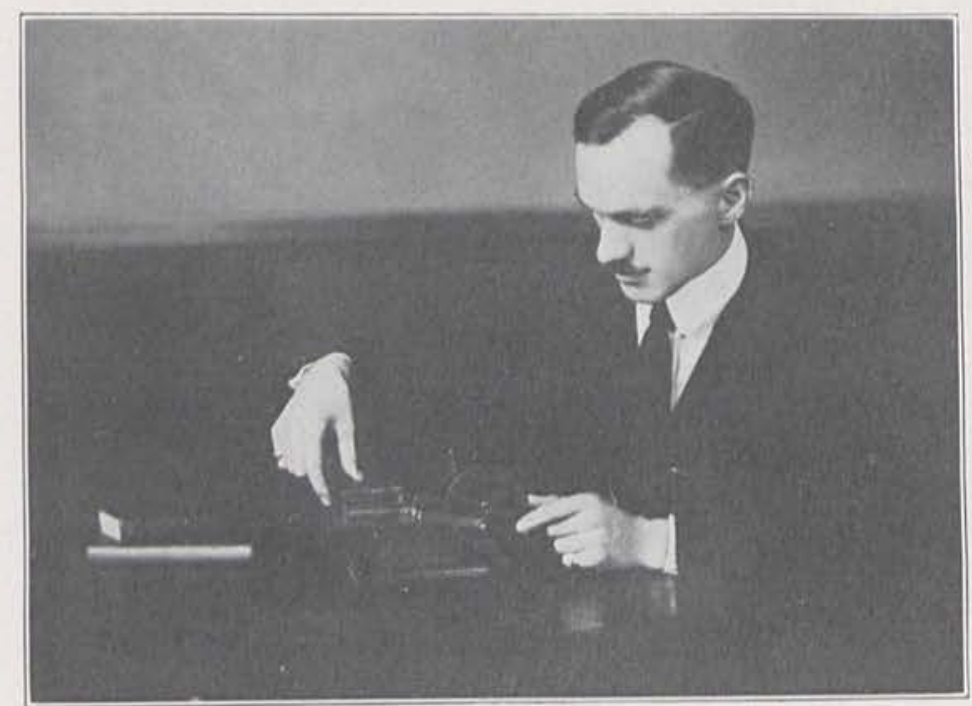

M. L. Fraser

Professor of Science

A. B., Wittenberg 1915

A. M., Wittenberg 1922

FLORENCE E. SOMERS

Professor of Mathematics and Education

A. B., Cedarville 1917

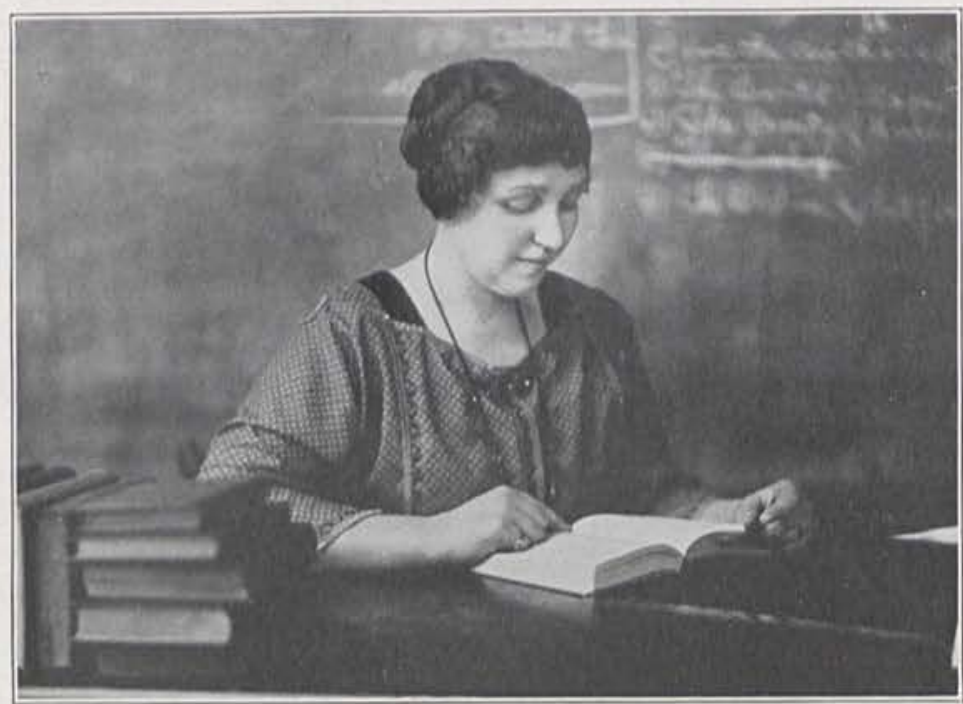




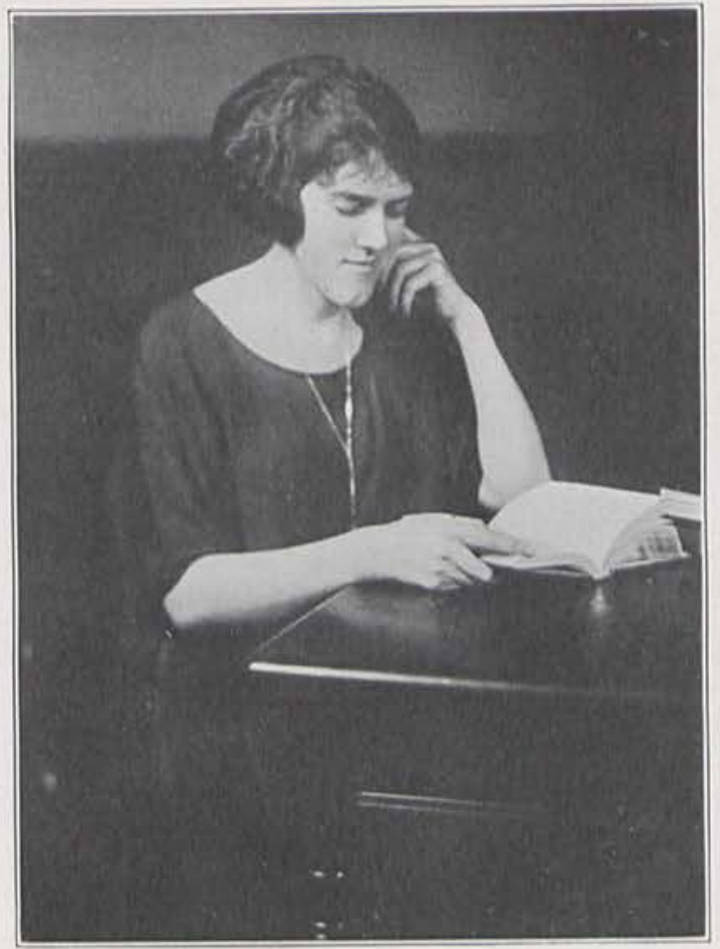

SARAH J. Porter

Preparatory Department

B. S., Tufts College 1922

Rev. W. P. Harriman

Seminary

A. B., Cedarville 1912

Western Seminary, Pittsburgh 1915

t

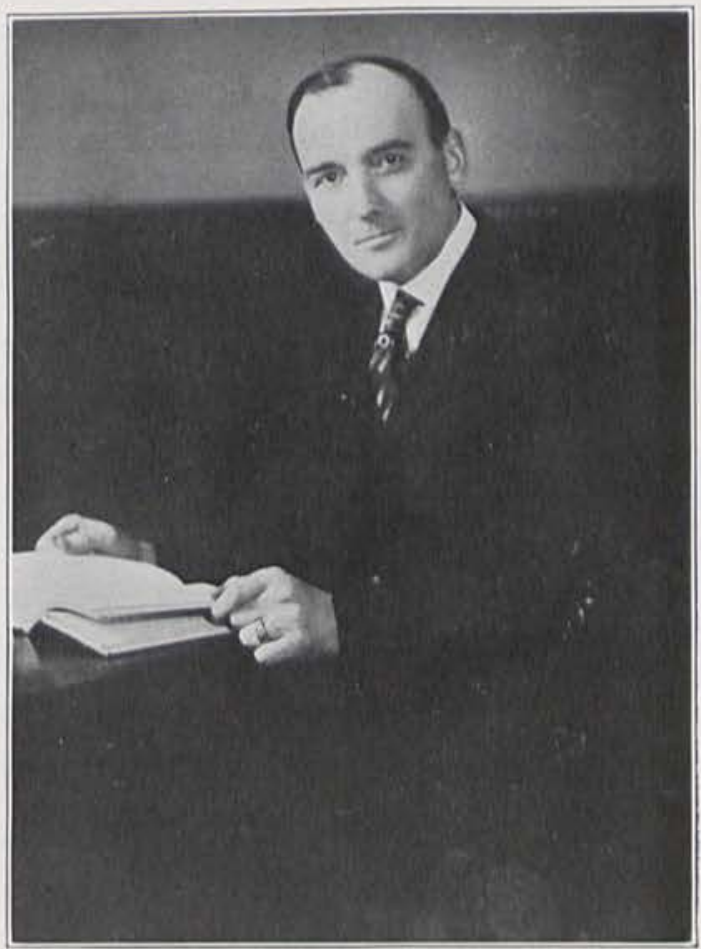




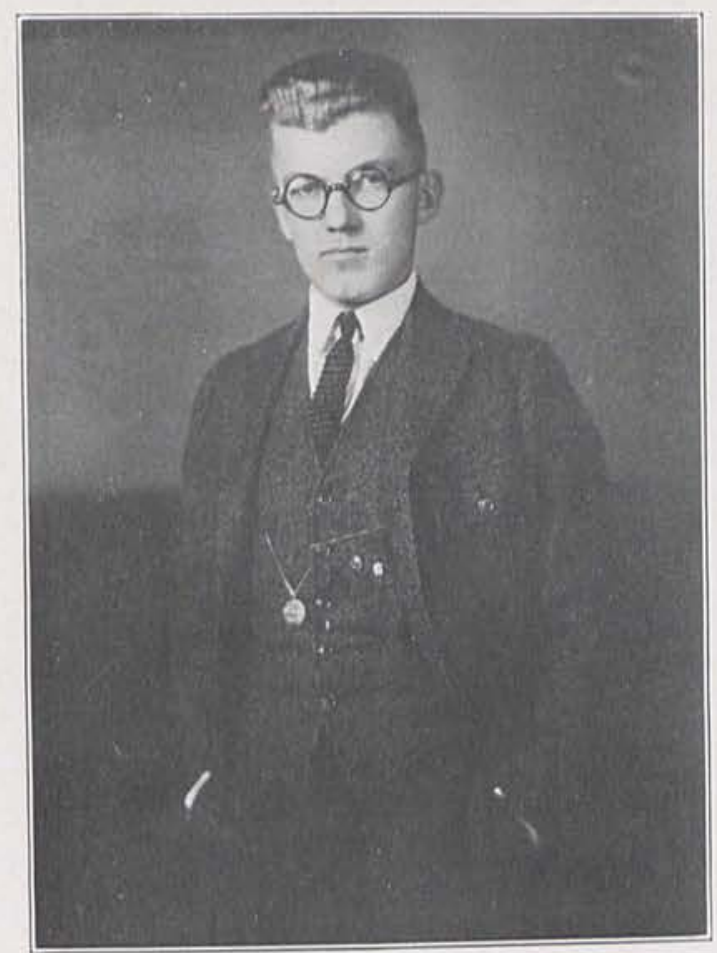

Chester P. WARner

Director of Physical Education

A. B., Ohio Wesleyan 1922

EMMA LOU SNOW

Director of Department of Music Graduate of

Cincinnati Conservatory of Music

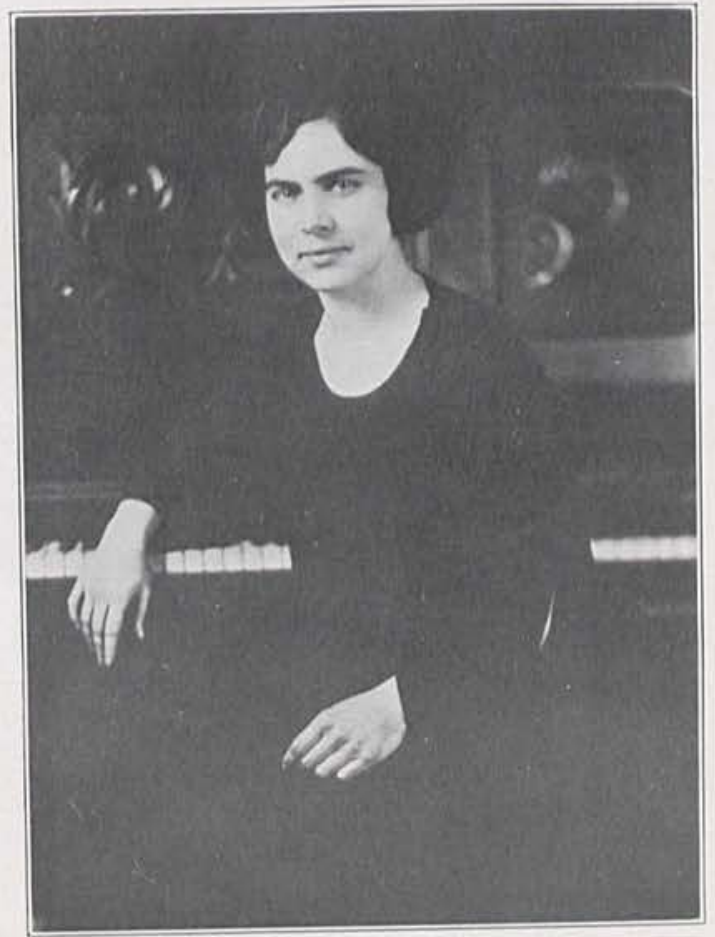




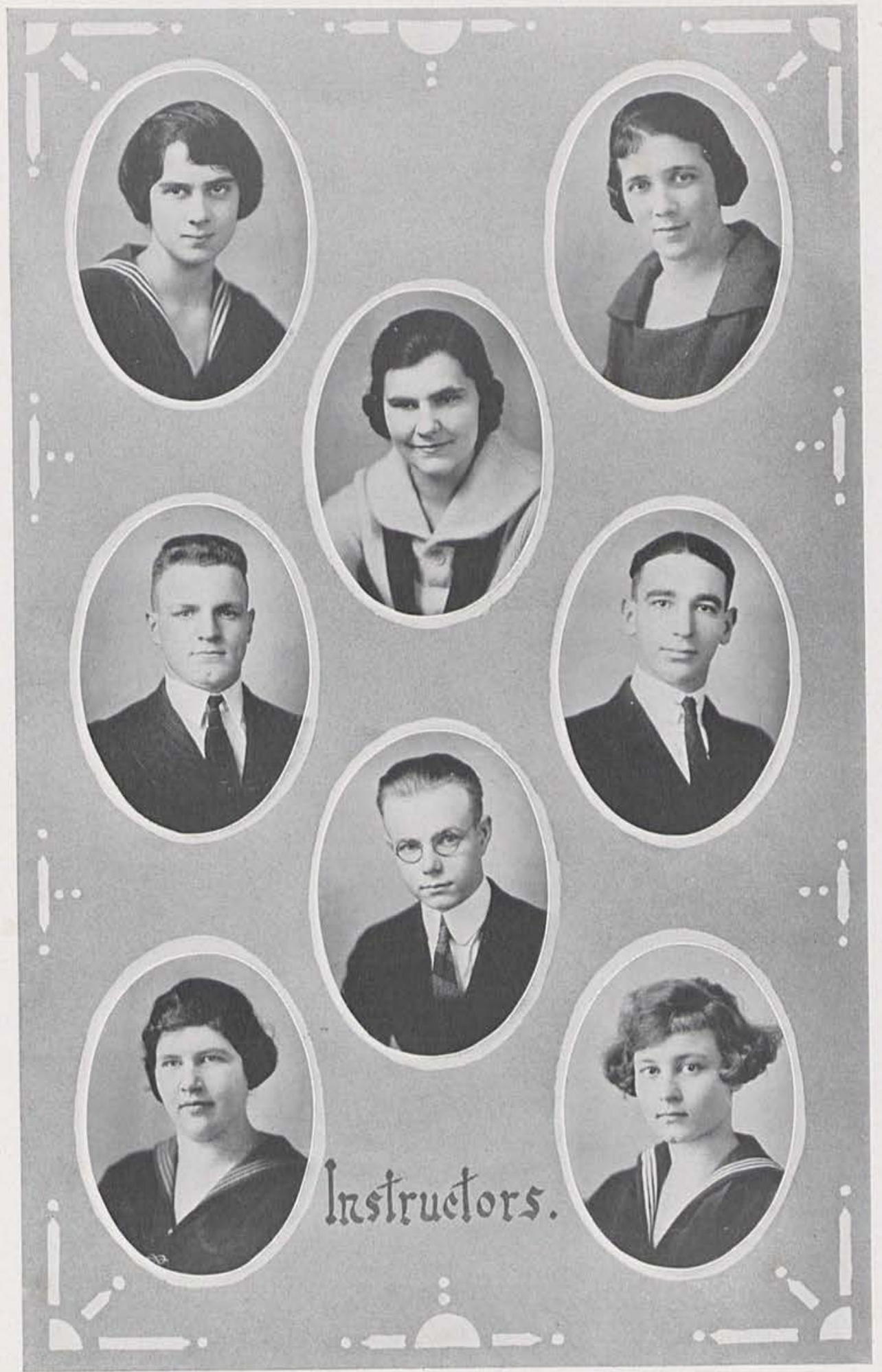




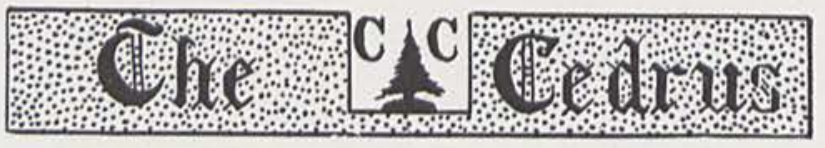

Mrs. John Pressley White

Lecturer on Christian Missions

Eloise Davis

Assistant in English

MaRY ERVIN WILliamson

Librarian

Mrs. Clara Morton

Club Cateress

DAVID WILLIAMSON

Janitor of Library

JOHN C. GRINDLE

Superintendent of Buildings and Grounds

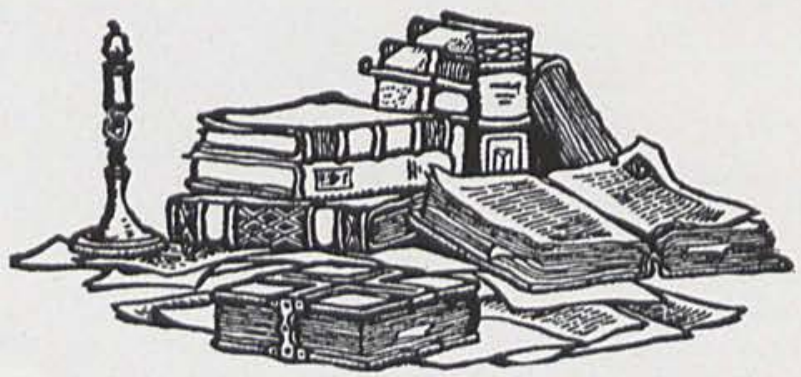




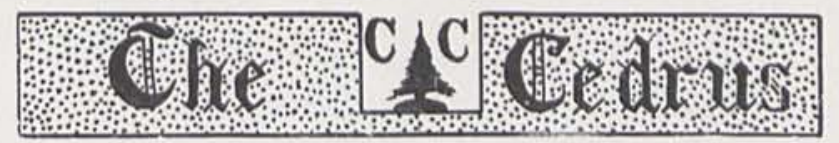

BOOK III - THE CLASSES

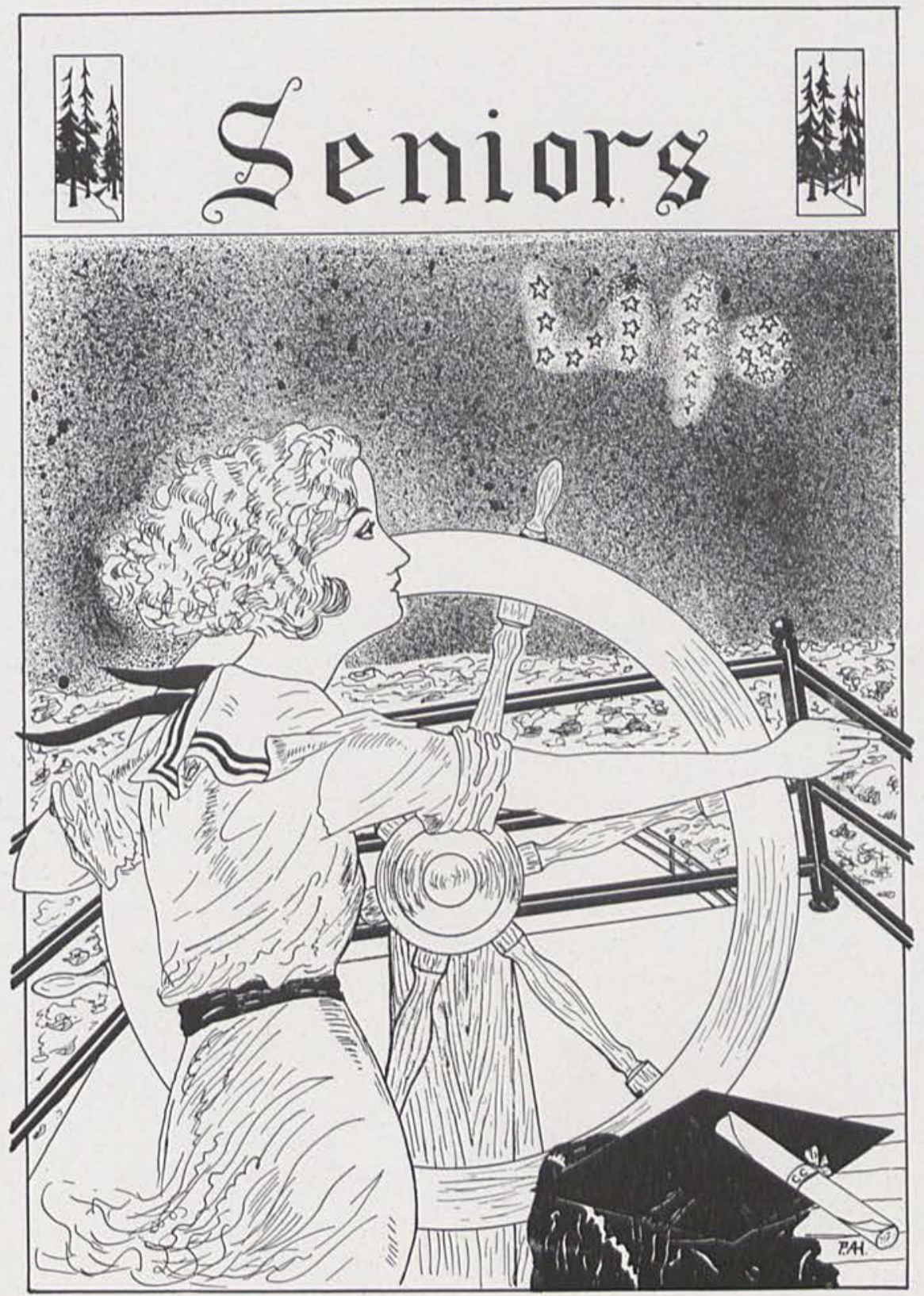



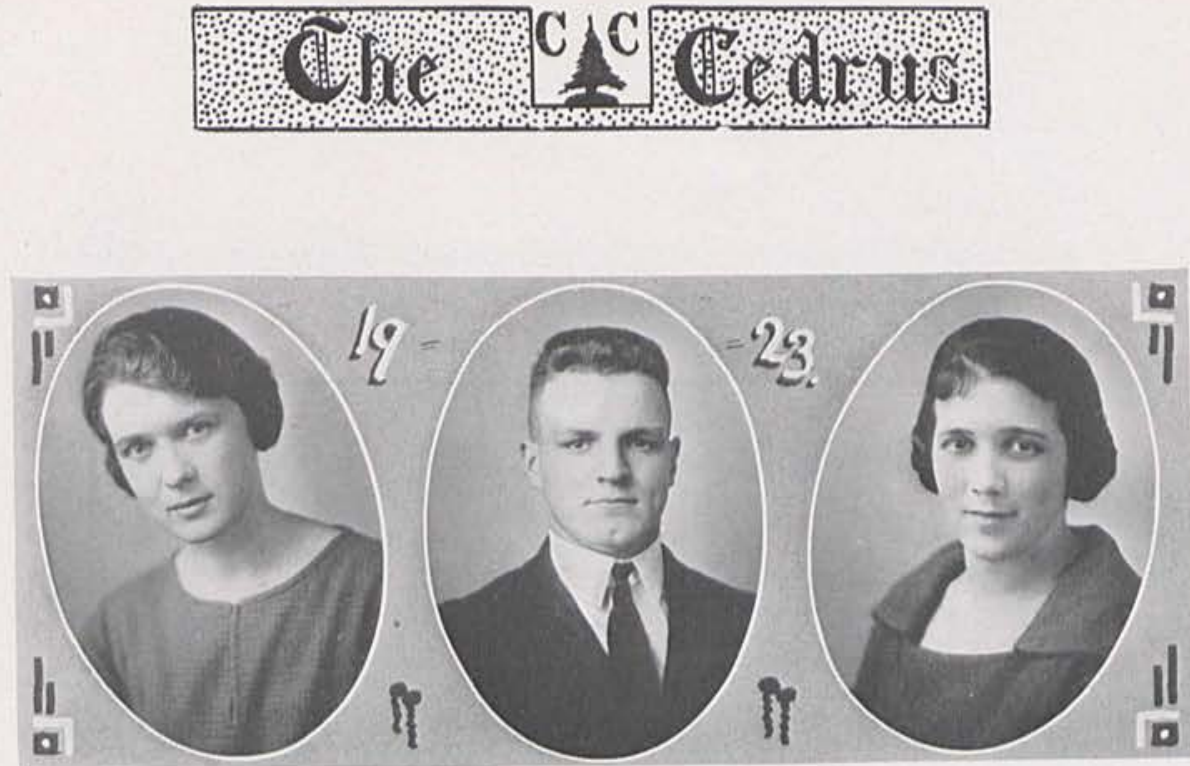

President, Earle Collins

Vice-President, Eloise Davis

Secretary and Treasurer, MARJORIE MCClellaN

\section{RETROSPECT 1923}

Seated around the blazing campfire on the old Indian Mound, attending the last feed that we would have as students of Cedarville College, we traced our college life from the fall of ' 19 when we were supreme in our little world as Freshmen; on as we gained a wider knowledge of earthly affairs as Sophomores; broadening out and developing into full-fledged men and women, as Juniors; and lastly our Senior year, when a deeper sense of responsibility gripped us. As we sat gazing into the glowing embers our fancies seemed to cluster about the friendships formed and the good fellowship we enjoyed, rather than upon the honors we received. A class spirit, loyal and affectionate, takes the place of the old factional feeling.

In the silence a glowing log rolls off the fire, casting a shower of golden embers in a glowing haze over the group. A wreath of smoke slowly rises in a never-ceasing promenade upward. Suddenly the smoke blurs and a succession of faces appear, then incidents follow quickly, one upon the other, before our reminiscing visions until the entire days of our college lives are unfolded.

We were forty-nine strong when we entered college; forty-nine wrapped in the expectation of their futures, which were to be so closely linked with the future of a greater Cedarville College. A billow of smoke suddenly unfolds itself before our vision. 


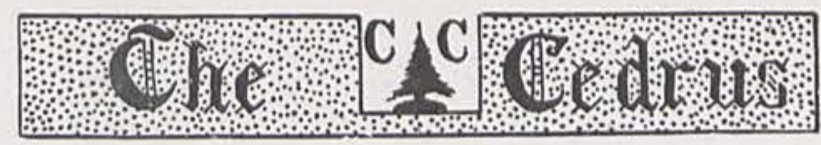

We see that first class election, our first realization that we were students in Cedarville College, taking the first step in what was to be the foundation of a career. Within a few days our fiery blood demanded action, and the girls' watermelon feed was transformed into a free-for-all, Freshies vs. Uppers.

Again we were brought together by watermelon feeds, corn roasts and truck rides. We often afforded the Sophomore class some belated hours, especially when we broke into Shaw's kitchen and stole the eats the night of their mock wedding. Well do we remember the first reception that we attended at Dr. McChesney's, which heralded our entrance into the butter-fly class. Spring brought with it many picnics, hikes and breakfasts. Cedar Day completed the year's festivities.

The logs smoulder and die; we put on another and in a moment the flames are gaily crackling. Our visions continue. We are now Sophomores. The R. P. Church reception was held as usual on the First Friday night and this time we shone in a more dignified manner. This year, too, was chucked full of thrilling events. The big annual spread at Shaw's terminated in a ham and egg feed this year rather than a chicken feed as last year. Our athletes began to make their prominent appearances and several of our number took leading parts in, "What Happened to Jones.”

Again we renew the fire. The vision is a startling one; we find ourselves mature. We are Juniors. We elected Earle Collins, President; Marjorie McClellan, Secretary. As Juniors we have our duties before us; some busy in athletics, or dramatics, and still others with the Rangers' club. The Junior class play, "Stop Thief," was a raving success. And to cap the climax of all social activities, the Junior-Senior banquet which we engineered, was held at the Bancroft Hotel, Springfield. We guided the Class of '22 safely through their commencement activities.

The fire still burns and burns; the glow brings us to the realization that we are now Seniors, still busy fitting and preparing for our "commencement which only spells" the beginning for us. In a few weeks we separate, each member will go his own way, mingle with the busy world and do his part completing the history of a great nation. May the ideals learned at Cedarville College help to mold our futures into bright and happy ones.

F. S. \& M. W. 


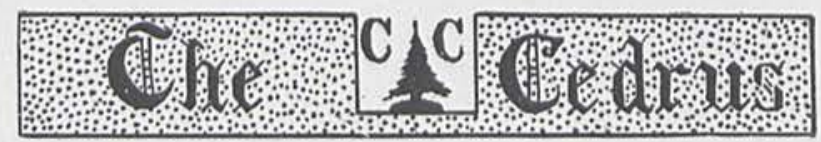

\section{LAST WILL AND TESTAMENT}

In the Name of God, Amen:-We, the Senior Class of Cedarville College in the year 1922-1923, being of sound and disposing mind and memory, do make and publish this our Last Will and Testament, in order to as justly as we may distribute our interests in Cedarville College, the village of Cedarville, and in college life, among succeeding young men and women who shall be students as we have been.

WITNESS: First, That part of our interests which is known in the law and recognized in the sheep-bound volumes as property, being almost inconsiderable, we hesitate to make any account of it. Yet on the other hand, realizing that our dear Prof. Jurkat, long. Treasurer of the College has no safe in which to keep all the valuable papers entrusted to his care, we are glad to bequeath to him the safe we so highly prized because of its ability to "STOP THIEF."

Second: Our right to be Seniors being granted to us only once and for the period of one year, it is not ours to bequeath that privilege. However, we do bequeath to the Junior Class, and to other classes in their annual turn the attitude of making the last year in Cedarville College one of pleasure and profit to all.

Third: We give to succeeding classes the right to vie with each other for the honor of having the most "pep" and originality, yet charging them always to remember that the qualities of ladies and gentlemen are expected from students of Cedarville College.

Fourth: We bequeath to the members of other classes the right to be leaders in the various sports and activities of student life, such as spreads, skating parties, class plays and mid-night parades, reminding such members that youth and the spirit of jollification do not remove the boundaries of the rights of good, upright citizens who are more loyal in answering the summons to Morpheus' realm.

Fifth: We leave to our successors the privilege of sitting about in the camp-fire circle on old Indian Mound and fashioning castles in the curling wreaths of smoke which rise from the dying embers, or of gathering in any other place where they may muse on what the future holds in store.

Sixth: We leave to our successors the right to go out into the broader walks of life seeking to make the world better, and purer, and a finer place in which to live, even as we are trying to do.

And, lastly, we leave to our Professors and Instructors in old Cedarville College our very best wishes and a double portion of our good will, asking them only to continue being kind and helpful to students who come under their care and instruction.

(Signed) SENIORS OF 1922-1923. E. D. MC. 


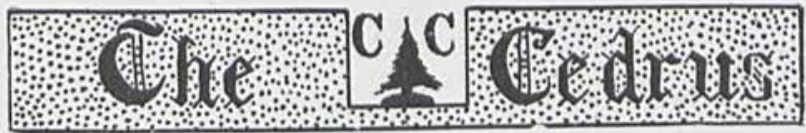

FAREWELL

\section{By E. D. McKunE, Valedictorian of the Class}

To you, our Alma Mater, we must now say Farewell. The parting of the ways has come at last. Your task has about been completed. Be it successful or not remains to be proved by what we are able to do. Whatever we may fail to do, however, we cannot blame you. We came to you as mere Freshmen, four years ago, and we yielded ourselves to your protecting care. We, doubtless, gave you lots of trouble for we were a group of young folks full of energy and enthusiasm, but we have forgotten all such things and are sure you have done so, too. Under your tutelage and instruction our outlook has been cleared and our horizon has been broadened so that now we no longer see things in the realm of self, but rather we see ourselves in a world of real men and women coping with real problems. We have submitted to the guiding influence of our Alma Mater until our former ideas of merely fitting ourselves to make a living have changed to the far greater and grander idea of making a life that is worth while. We enjoy life now, not by making ourselves a nuisance, but in making ourselves helpful to others. So all our mistakes and grievances, we are sure, you'll forget and forgive as we leave you now.

Going out to a life, not new but only more full and complete, we are sure we will appreciate the foundation principles laid down in our lives. Too, we will appreciate the kindly interest with which our careers will be followed.

Nor, will we soon forget the days in the halls of old Cedarville College. As we go from state to state, from clime to clime, from sea to sea, we will be wishing for our Alma Mater many things. Among these would be listed the desire for an ever-deepening and widening circle of radiating influence from her sacred walls, and many loyal sons and daughters to bear tribute to the institution. May the studies become as much a joy as the social pastimes, and may the athletic contests be greater and better each year in that phase of college life which they fill.

In fact, our Good-bye wish for Cedarville College is that she may become the biggest and best college in all the land, and may her heritage be the honor of fitting Christian young men and women for LIFE.

\section{So say the "SENIORS OF TWENTY-THREE."}

(Valedictorian of the class was chosen by the faculty on a basis of grades at the end of the first semester of this year.) 


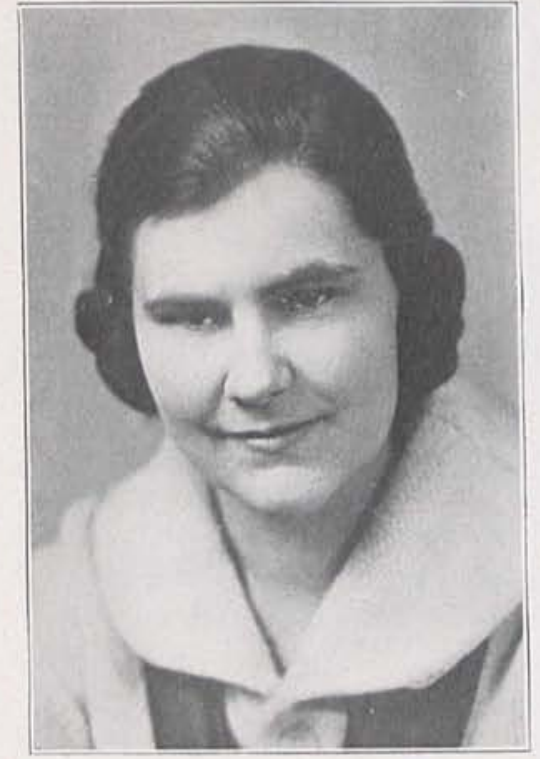

Edwin D. MCKune

Bellefontaine, Ohio

Arts, Diploma from Seminary

"Wise, grave, and dignified."

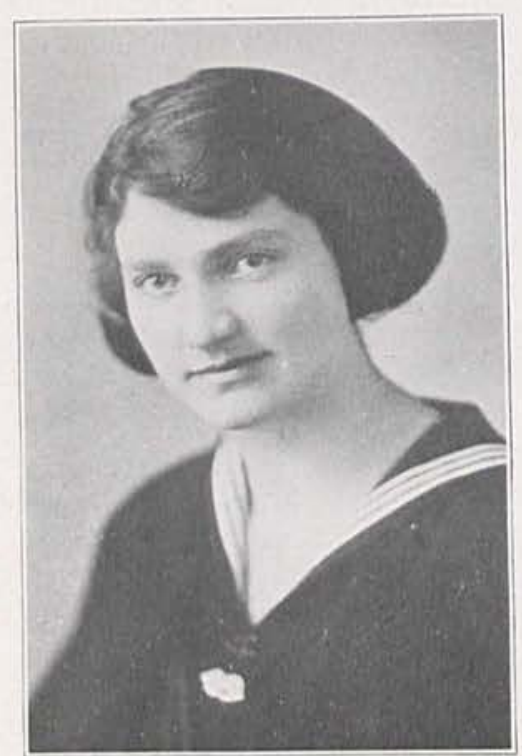

\section{MARJORIE WRIGHT}

Cedarville, Ohio

Arts, Education

"First you see her, then you don't,

She'll be naughty, then she won't."

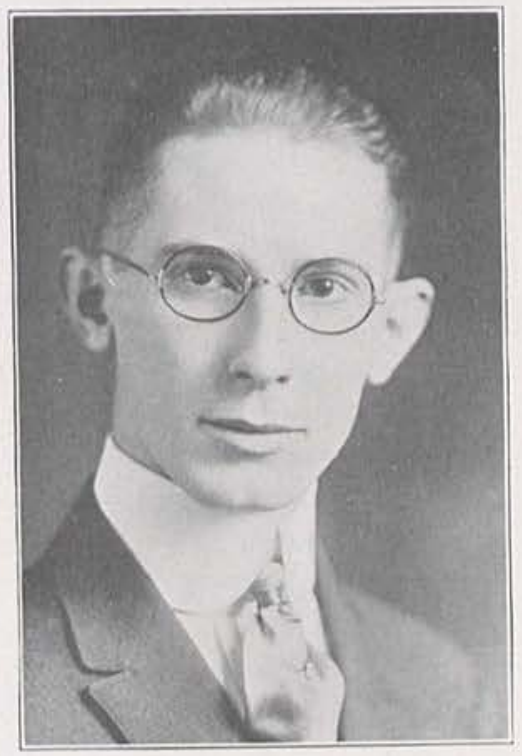

Florence E. SMith

Cedarville, Ohio

Arts, Education

"Not a star but a comet. Her position in the constellation of students and athletes is well assured." 


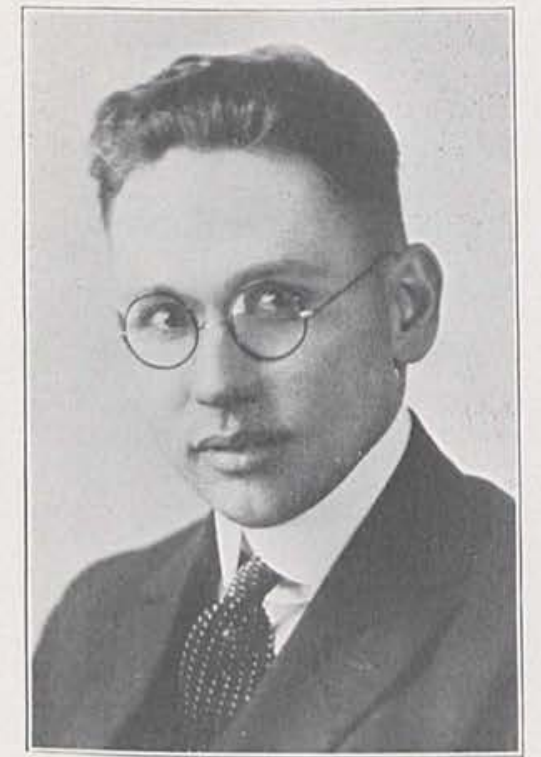

Mary L. Flanagan

Cedarville, Ohio

Arts, Education

"She knows that nothing is impossible to diligence and skill."

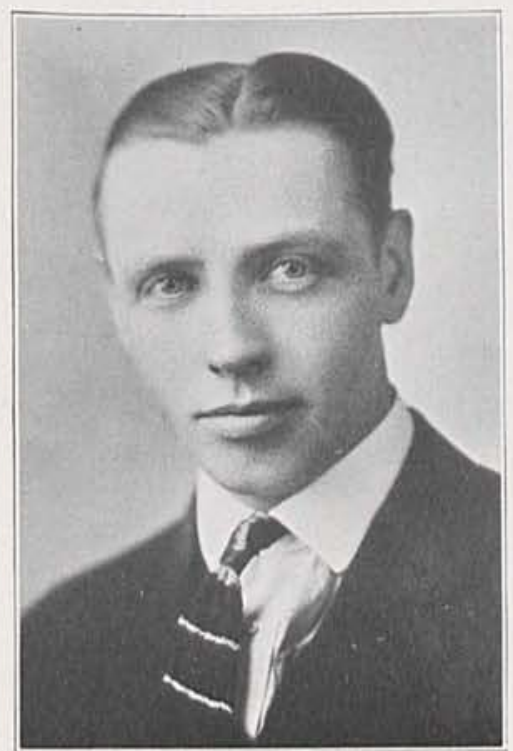

ROBERT W. STEWART

Coulterville, Illinois

Arts, Diploma from Seminary

"A business man of the day; very, very busy."

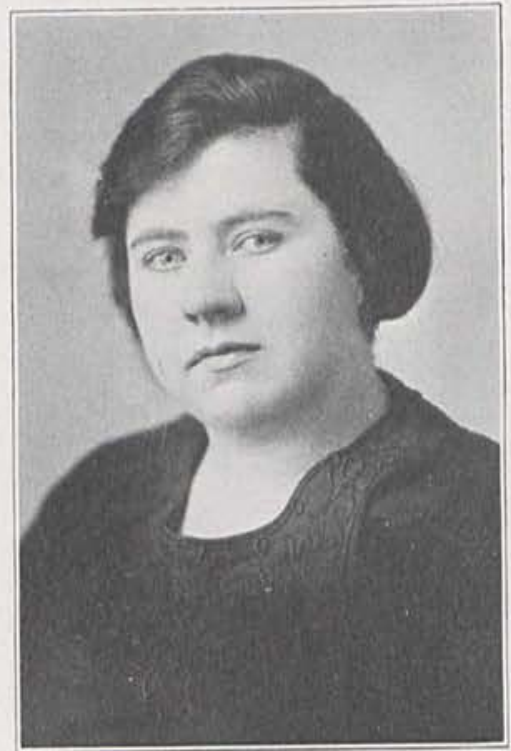

ARThur Cecil EWBANK

Cedarville, Ohio

Arts

"I vow that my life for me is one long snap." 


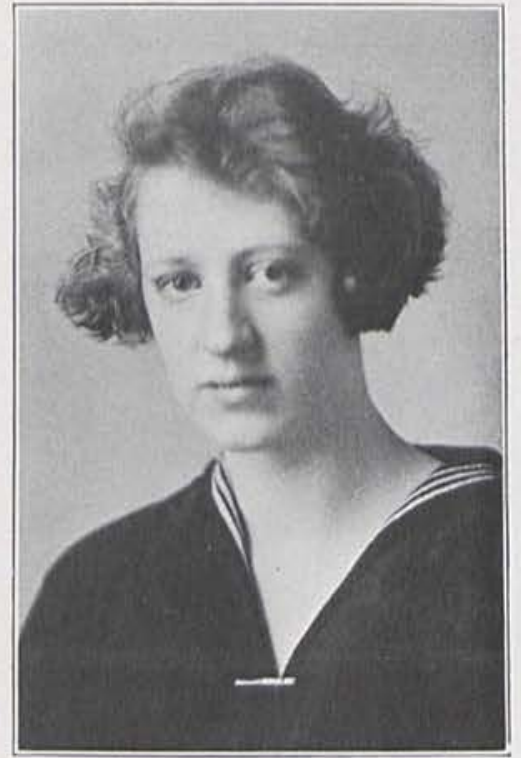

M. Earle Collins Cedarville, Ohio Arts, Education

"Come storm and tempest of life Ye shall ne'er ruffle my calm and staple soul."

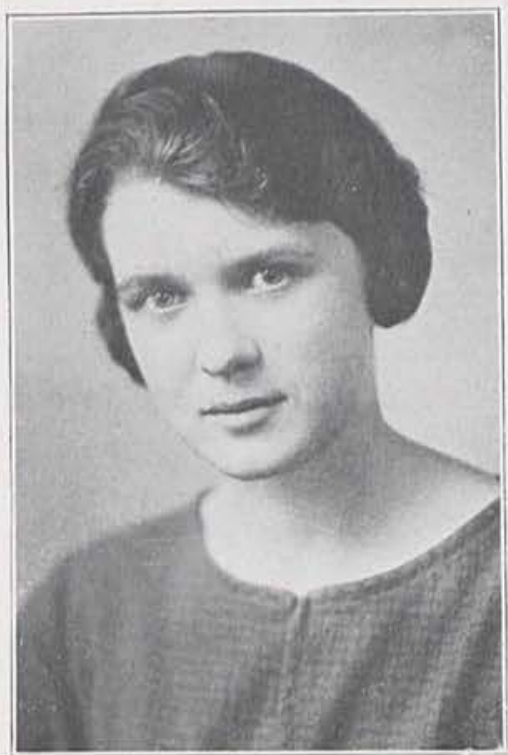

RUTH E. SHAW

Yellow Springs, Ohio

Arts, Education

"She is a queen of athletes."

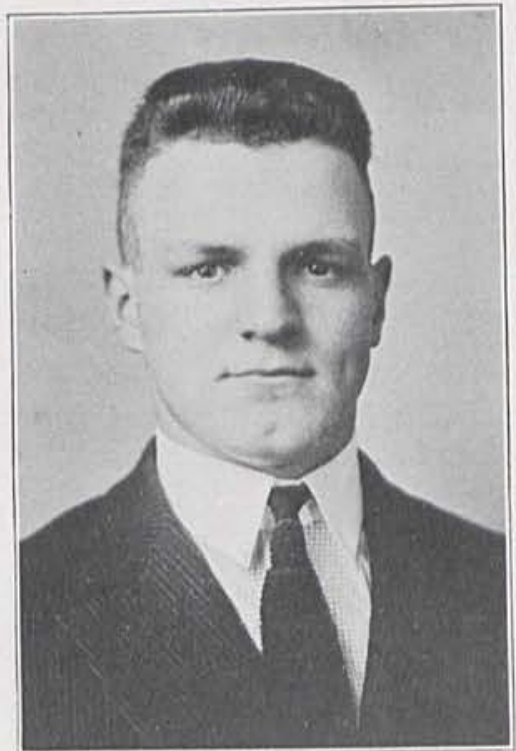

Mary Eloise Davis

Cedarville, Ohio

Arts, Education

"None knew thee but to love thee,

None named thee but to praise." 


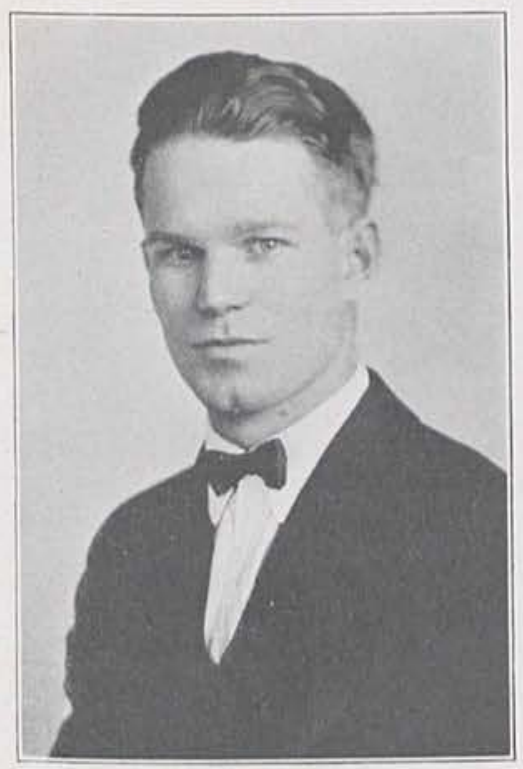

Alice K. LACKEY

Cedarville, Ohio

Arts, Education

"Her perfection in everything she undertakes is a joy to the class in which she recites."

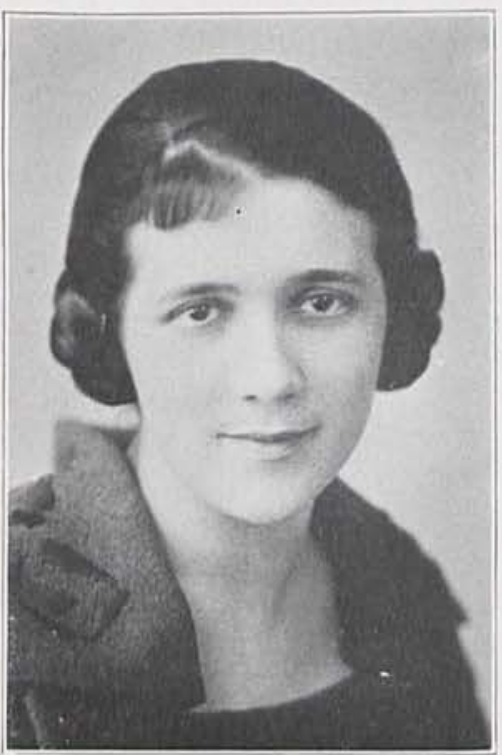

JAMES C. KYLE

Cedarville, Ohio

Arts

"Your modesty Jim is all in vain;

True worth cannot be hidden."

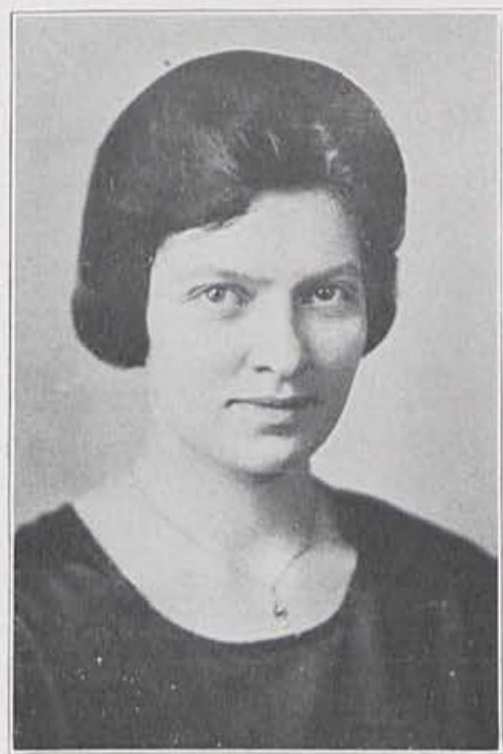

MarJorie D. MCClellan

Joplin, Missouri

Arts, Education

"For nature made her what she is and never made another." 


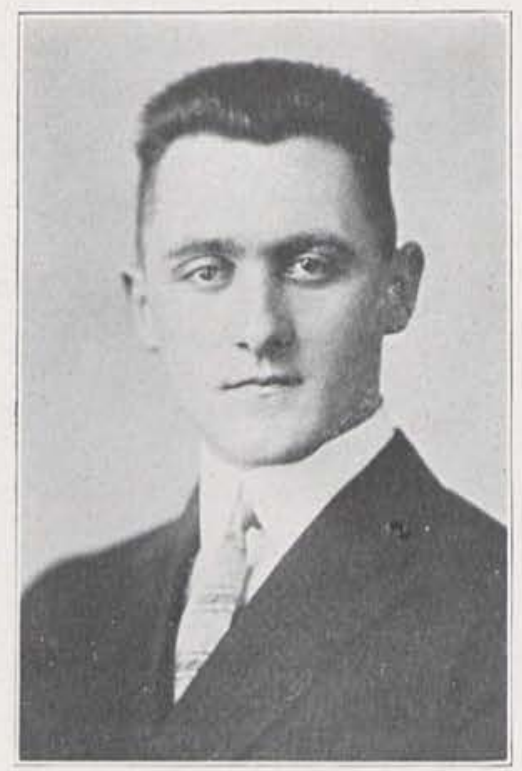

\section{ERNEST WRIGHT \\ Xenia, Ohio \\ Arts, Education}

"A man he seems of cheerful yesterdays and confident tomorrows."

IDA E. REES

Camden, Ohio

Arts, Education

"She just kinda looks good-natured at a sour old world."
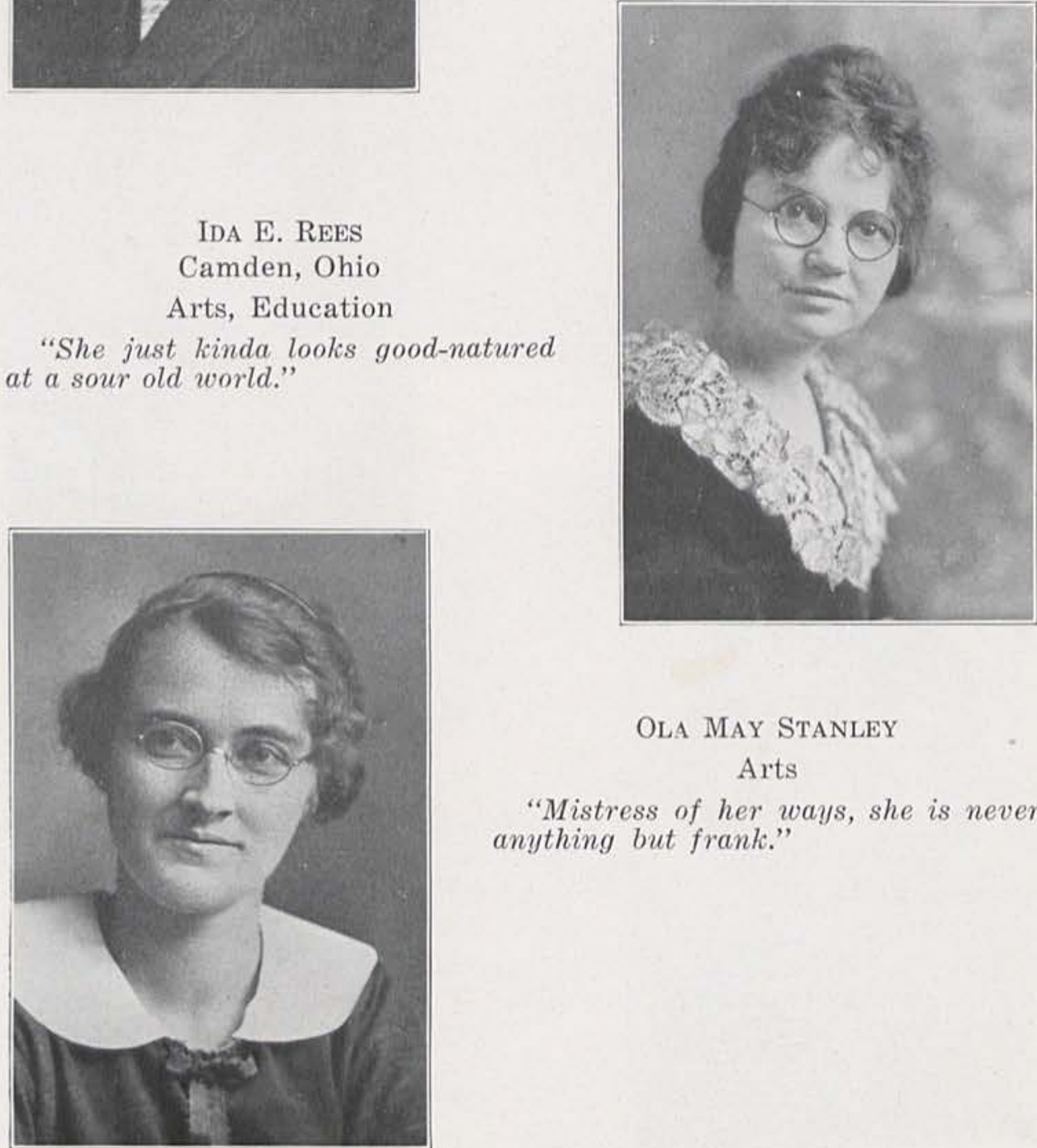

\section{Ola May Stanley \\ Arts}

"Mistress of her ways, she is never anything but frank." 


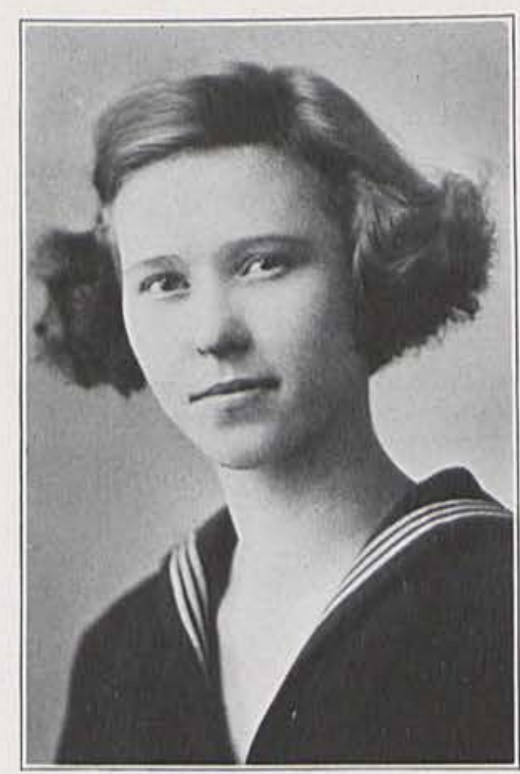

PAUline Collins

Cedarville, Ohio

Diploma in Music

"She's a bonnie and a cannie lassie, conquering many with her charming smile."

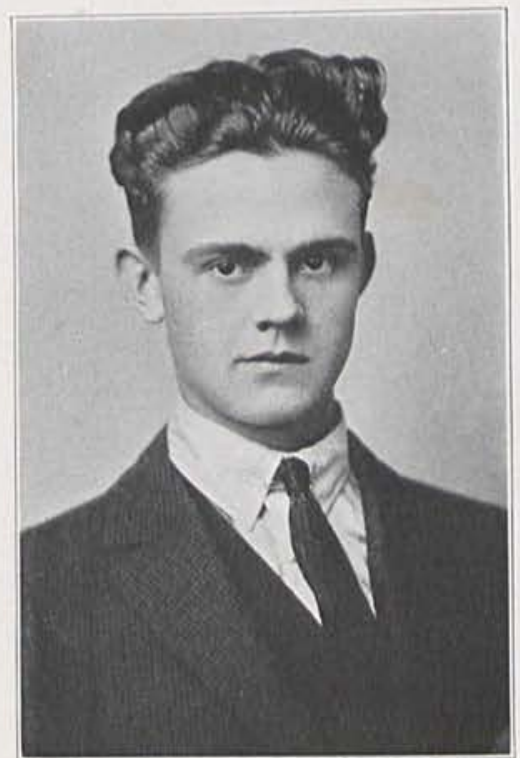

Alberta Hemphill

Coulterville, Illinois

Diploma in Music

"The mildest manner with the bravest mind."

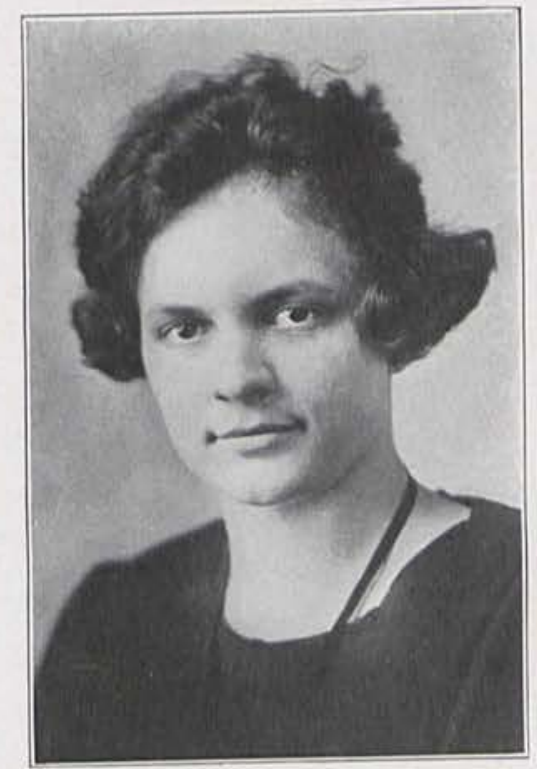

WILLARD BARLOW

Cedarville, Ohio

Diploma in Music

"With his music he drives dull care away." 

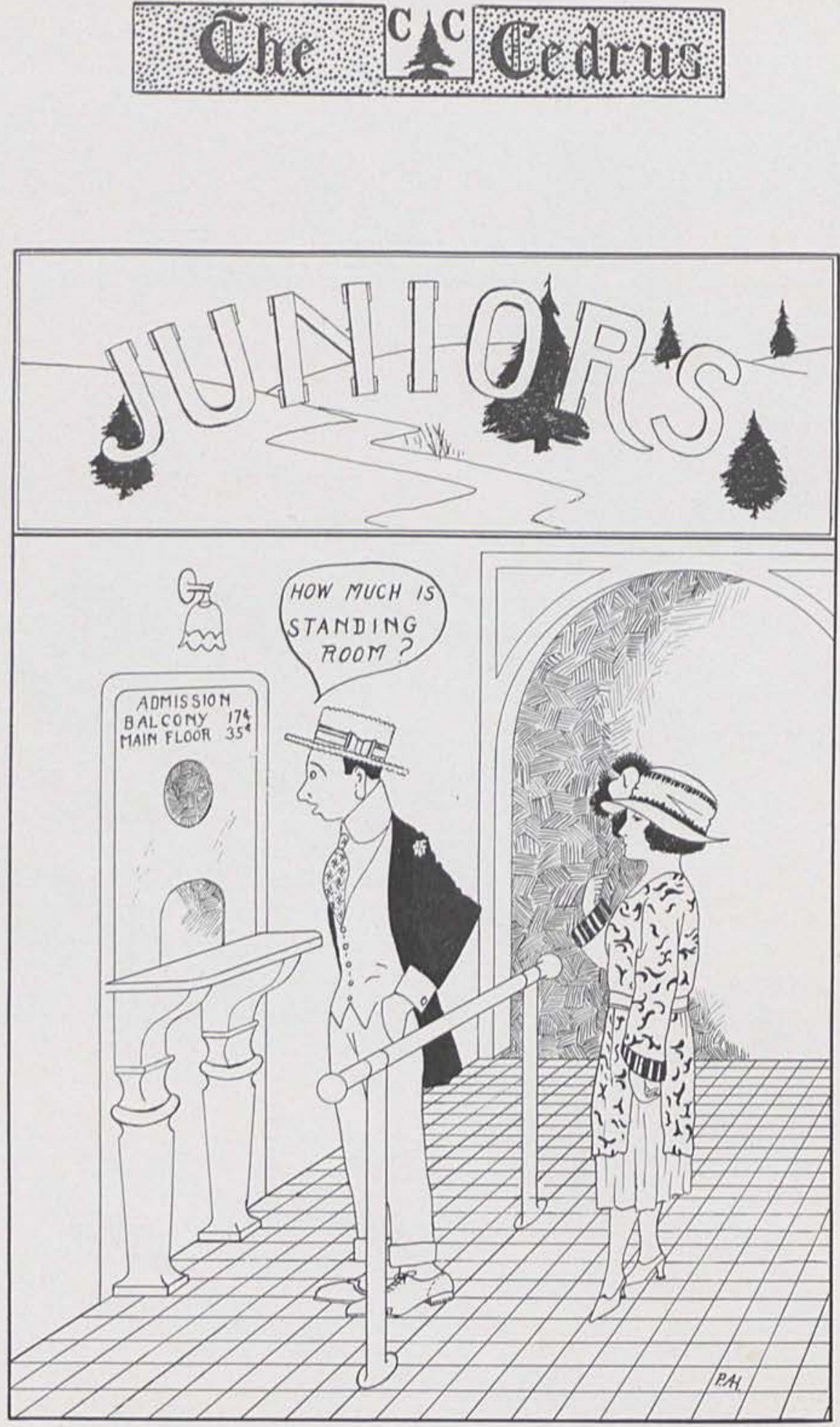

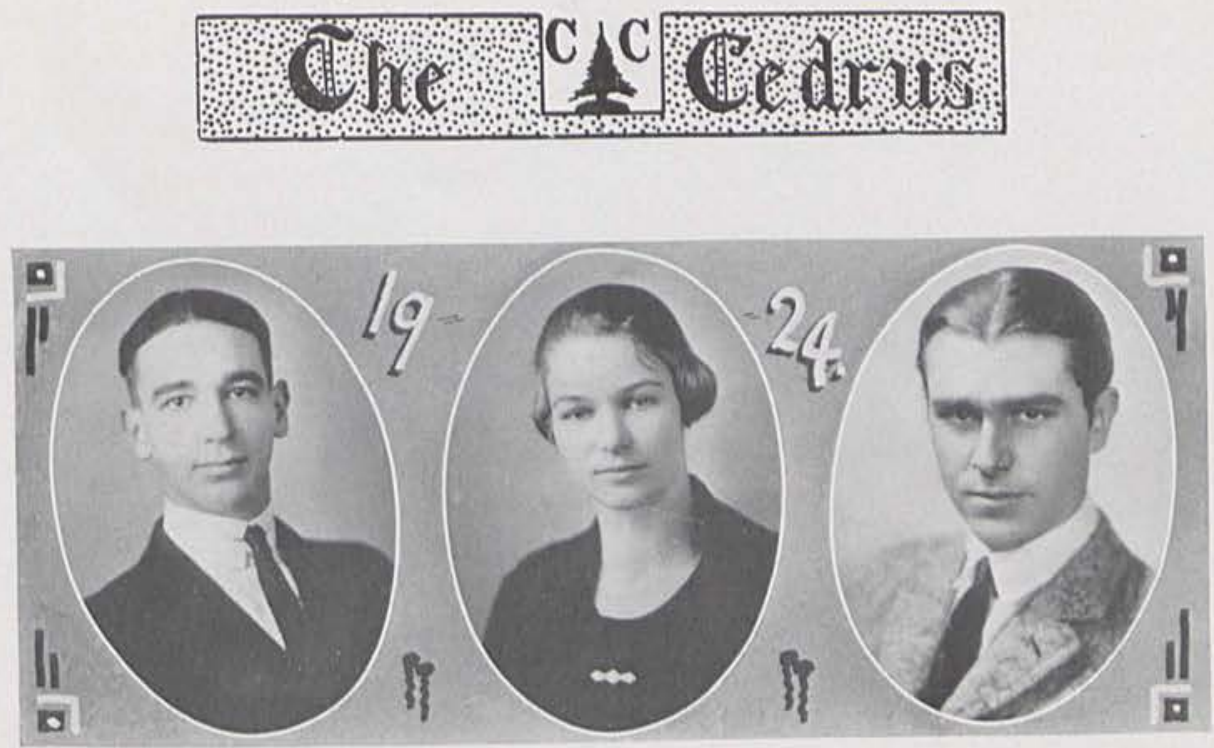

President, Donald Wickerham

Secretary, CHRISTINA KYLE

Treasurer, HARPER BICKETT

\section{JUNIOR CLASS HISTORY}

Freshman days have passed long ago, but we like to recall beginnings of college life, entirely strange to most of us; the unfamiliar faces that met our glances which sometimes bespoke us "greenies." However we soon found our places and became easily accustomed to college life. We could not be happy without some good times nor could the upper classmen be content unless we afforded them the opportunity of some sport at our expense. At our first two spreads, we were too fleet for the Sophs but the fleetness wore off and our machines were quite disturbed in the field across from Glass's. We were not pursued to our happy Thanksgiving spread in Spring Valley.

Not all our members returned to us the next year but the class though smaller was just as much alive. Again the Juniors, feeling indignant at us for having escaped their barber's tool, "swiped" one of our machines from Bickett's lane. Examinations had been thrust upon us and we celebrated their completion by a chicken supper at Johnson's. The last semester of the second year passed very, very quickly and we became Juniors long before we were willing.

Again we were destined to lose some of our members and there are now just fifteen left. But though we are few in numbers, we are still that happy class that entered college in '20. We have had our spreads, at Kyle's, at Williams' and have cemented our friendships with the Seniors by the last Junior-Senior spread at Johnson's. We have had our good times and our hard luck and are now planning for hard work on our Junior Class Play. We expect to treat the Seniors loyally and to banquet them in the spring.

T. M. D. 


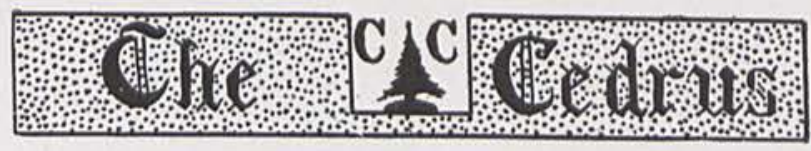

\section{JUNIOR CLASS POEM}

Here's to the Juniors of Old C. C.!

We're as jolly and as happy as can be:

When once you hear our laughter,

And the noise of youthful chatter

You can't help but have a sense of jubilee.

For wisdom we can't be beat.

We're the brightest that you ever will greet:

And I'm sure you would agree

If all our "A's" you'd see,

We're the sort that professors like to meet.

We're not wild-but we are game,

Never would we mar our name.

We are the pride of old C. C.,

And ne'er slothful will we be,

For we're destined for great Fame.

As for talents we are just fine,

We are found in every line.

Orators, players and great athletes,

While on the stage we can't be beat,

And our singing's sure divine.

So, Hail to the Class of ' 24 !

Our equal you will meet ne'er more.

When the next year rolls around

We shall each one have a crown?

And be ushered with triumph through the old College door.

\section{LUCINDA CASKEY.}



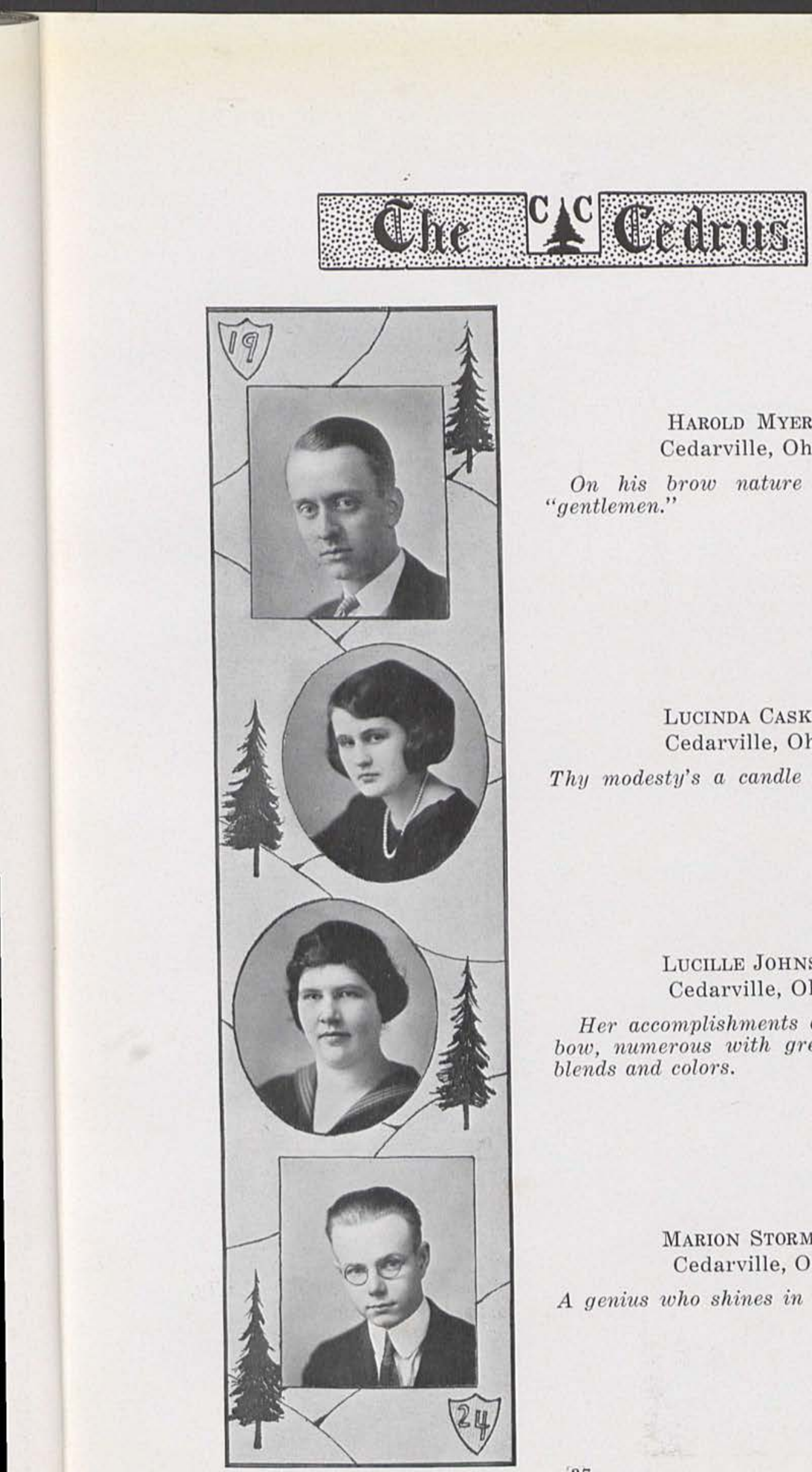

HAROLD MYeRS

Cedarville, Ohio

On his brow nature has written "gentlemen."

\section{LUCINDA CASKEY}

Cedarville, Ohio

Thy modesty's a candle to thy merit.

\section{LUCILLE JOHNSON \\ Cedarville, Ohio}

Her accomplishments are as a rainbow, numerous with great variety of blends and colors.

\section{MARION STORMONT \\ Cedarville, Ohio}

A genius who shines in all his classes. 

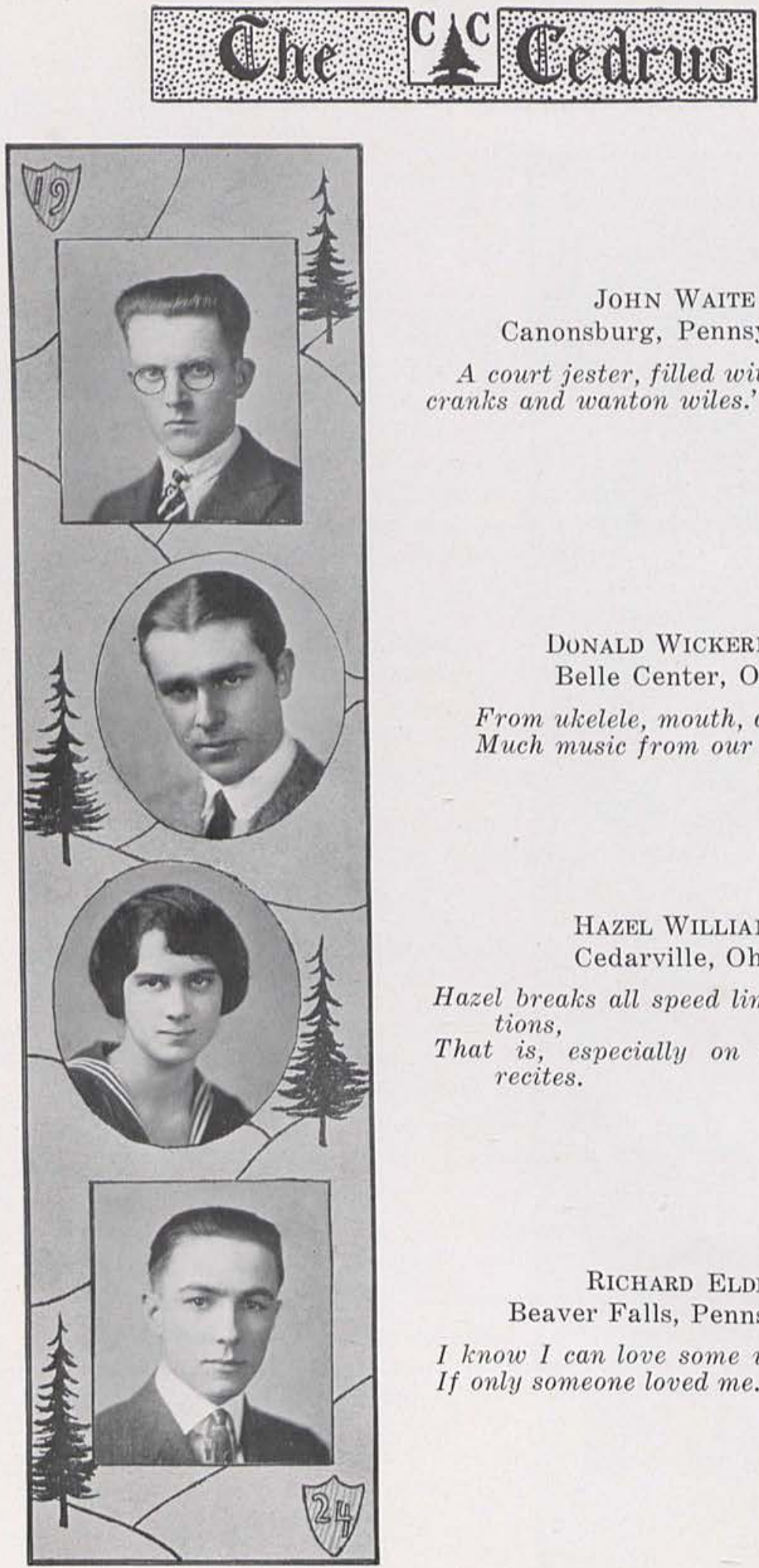

\section{JOHN WAITE}

Canonsburg, Pennsylvania

A court jester, filled with "quips and cranks and wanton wiles."

\section{DUNALD WICKERHAM}

Belle Center, Ohio

From ukelele, mouth, and nose,

Much music from our Don arose.

HaZel Williams

Cedarville, Ohio

Hazel breaks all speed limits in recitations,

That is, especially on the day she recites.

RICHARD ELDER

Beaver Falls, Pennsylvania

I know I can love some woman madly, If only someone loved me. 

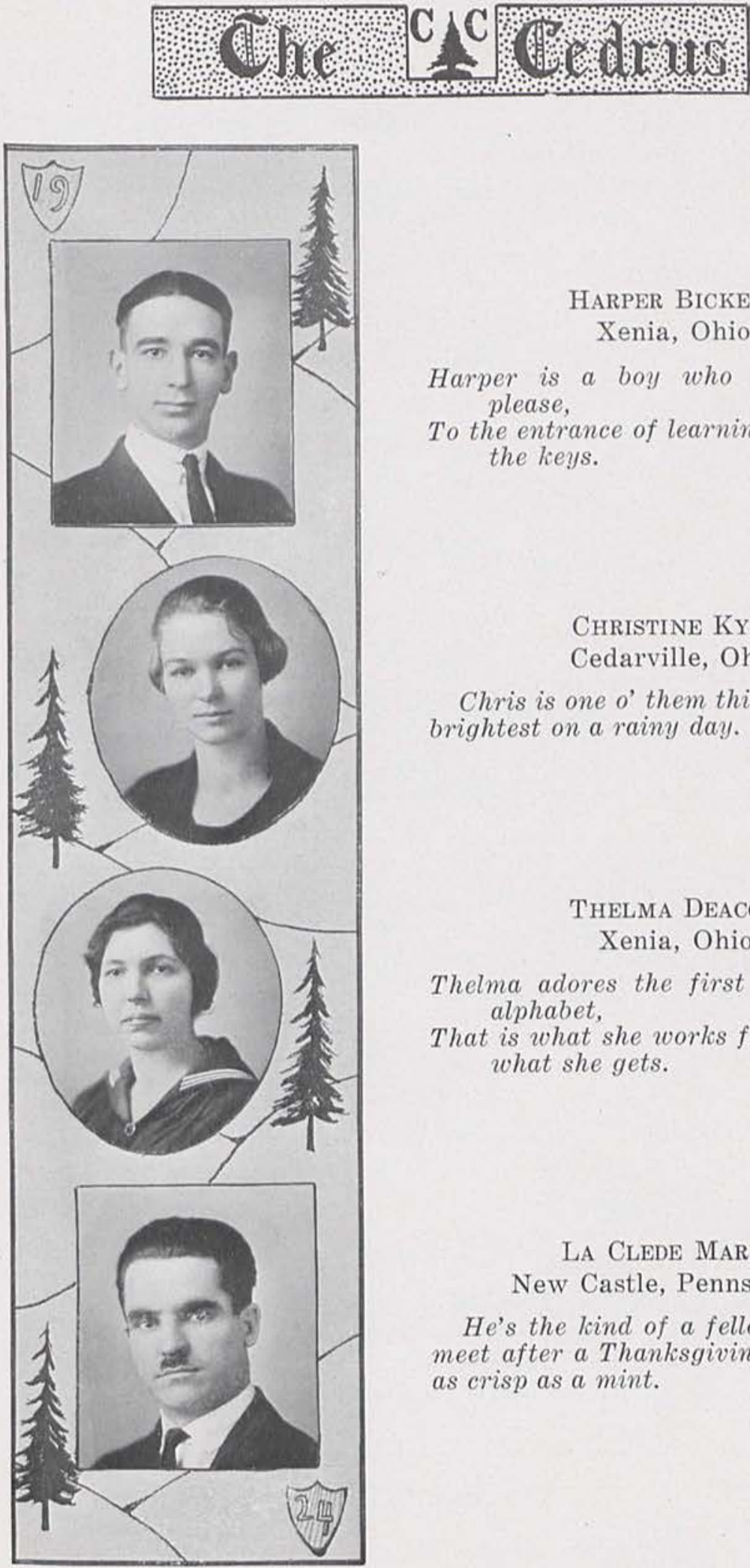

\section{HARPER BICKETT \\ Xenia, Ohio}

Harper is a boy who endeavors to please,

To the entrance of learning he holds all the keys.

\section{Christine KyLE \\ Cedarville, Ohio}

Chris is one o' them things that looks brightest on a rainy day.

\section{Thelma Deacon \\ Xenia, Ohio}

Thelma adores the first letter of the alphabet.

That is what she works for and that is what she gets.

La Clede Markle

New Castle, Pennsylvania

$H e$ 's the kind of a fellow you like to meet after a Thanksgiving dinner, he's as crisp as a mint. 

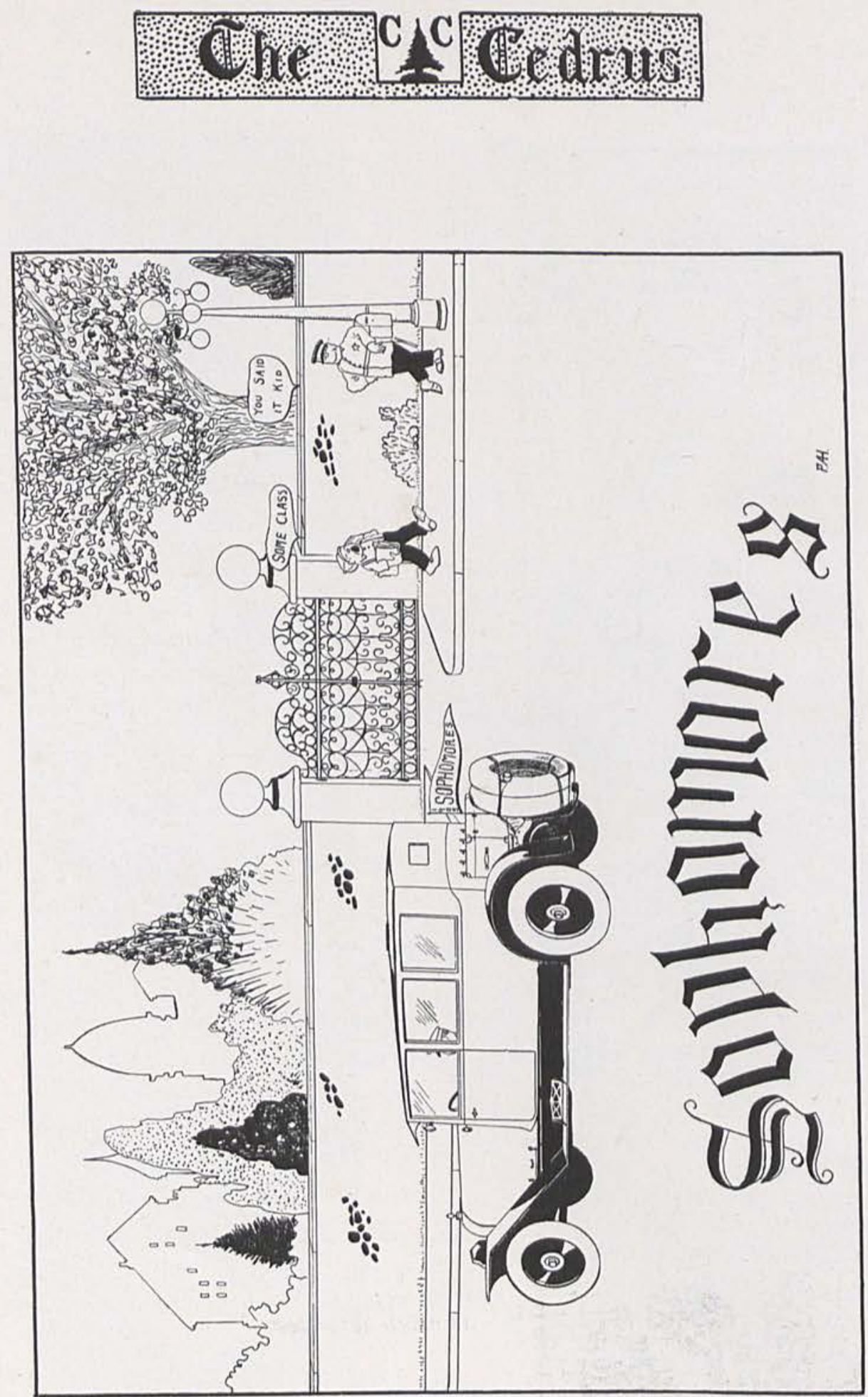

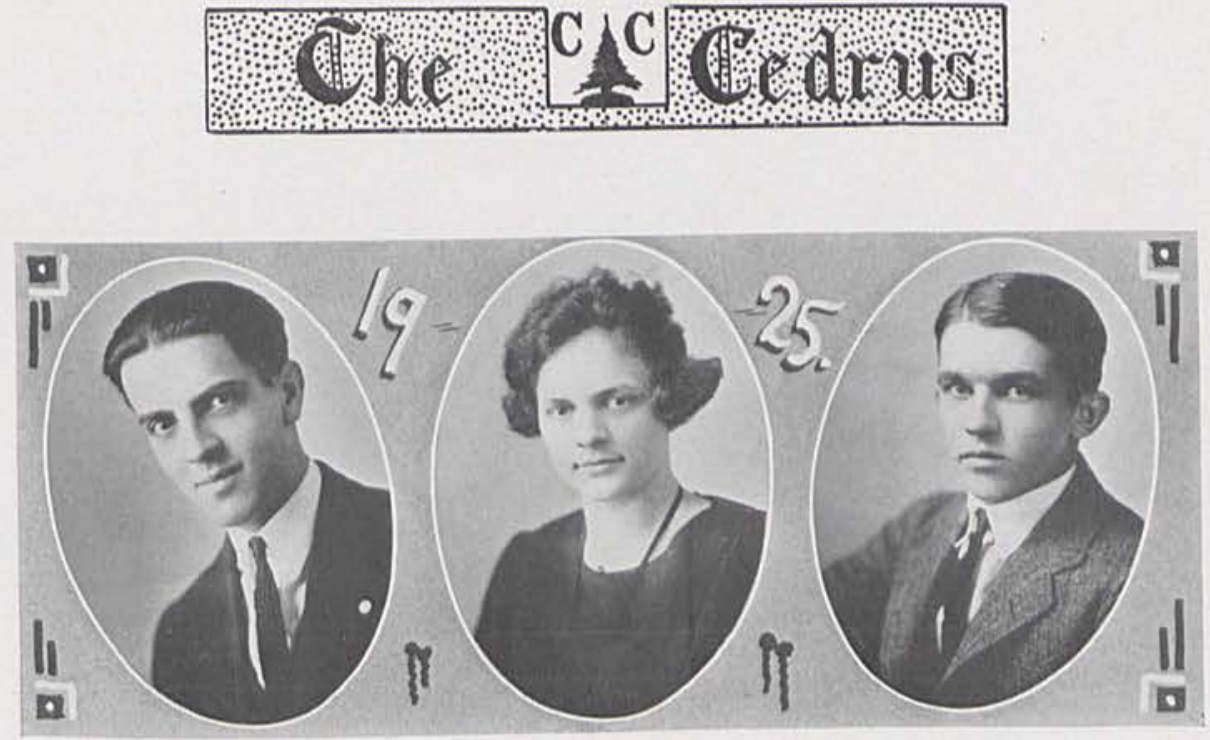

President, WaLker TAYLoR

Vice-President, JoHnNy Davis

Secretary and Treasurer, PAULINE Collins

\section{SOPHOMORE CLASS HISTORY}

We, the Class of '25, took our great plunge from high school into college, with all its strangeness and newness, much as a small boy who is thrown into a shallow pool for his swimming lesson.

As a good start for co-eds, we readily made a name for ourselves as Freshmen. Even if the upper classmen did interfere, our first Freshmen Spread caused quite a splash in the pool. Then people took notice, and when a leading man was wanted for the Annual College Play, all eyes turned to Walker Taylor, the noted Freshman Thespian.

In our Sophomore year we returned with new vigor and enthusiasm. In athletics the Class of ' 25 supplies some shining lights in football and boys' and girls' basketball. We also have the unique honor of claiming the captains of these three main sports.

We are well represented in all college activities; literary, athletic, musical, dramatic, religious and social. Our scholarship is high and we are trying to keep it so. We believe the best all-round student to be the one who is interested in all college affairs, including social activities, but one who does not allow outside affairs to interfere with his studies. We are very proud of our class organization, and believe we can accomplish much with our capable officers and loyal members.

We are ambitious for our college; we are also ambitious for ourselves individually but more than this, we are working hard to fulfill our highest ambition, that this Class of ' 25 shall be ready to plunge into life with its difficulties to be faced and overcome.

Ruth Mc. 


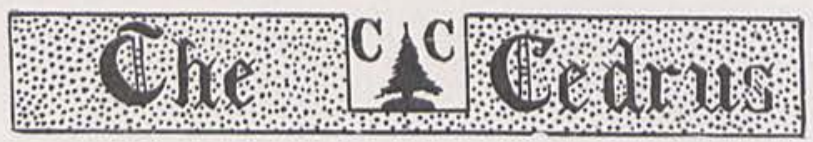

\section{SOPHOMORE IDEALS -- OPERETTA}

Proem (With apologies to Mother Goose)

"Where are you going, my pretty Soph?"

"To Cedarville College, sir," she quoth.

"As a Soph'more you're fortunate, Miss, for 'tis true

That's the classiest class at old Orange and Blue."

Strophe (with apologies to none)

The New Year came; and passed our doors, Still we continue Sophomores.

We occupy as strange a position

As those enforcing Prohibition.

Or, as the Ancients 'tween the rocks

We're doomed, on either hand, to knocks;

We raise our heads for one glance 'round-

Where have we been? Where are we bound?

\section{Intermezzo}

Some laugh at us ("Mere Sophies, eh?")

Who know the meaning of our name;-

Yet wise and foolish both were they

Whose records fill the halls of fame.

\section{Antistrophe}

Two decades hence still must we be

Crude Sophomores as now you see

With problems taxing mind and heart

At loss to know and do our part

While some among the tribe of men

May need our hands, our tongues, our pens?

God grant, ere lost 'mid storm and strife,

We each may find the goal for life:

That even though our scope be small

We'll seldom fail and never fall:

That realizing we've a limit

We'll touch and influence all that's in it.

Postlude (With apologies to all)

We may always know a little-

We can never know it all-

We may lay a brick or boulder,

Though we never build the wall.

C. B. 


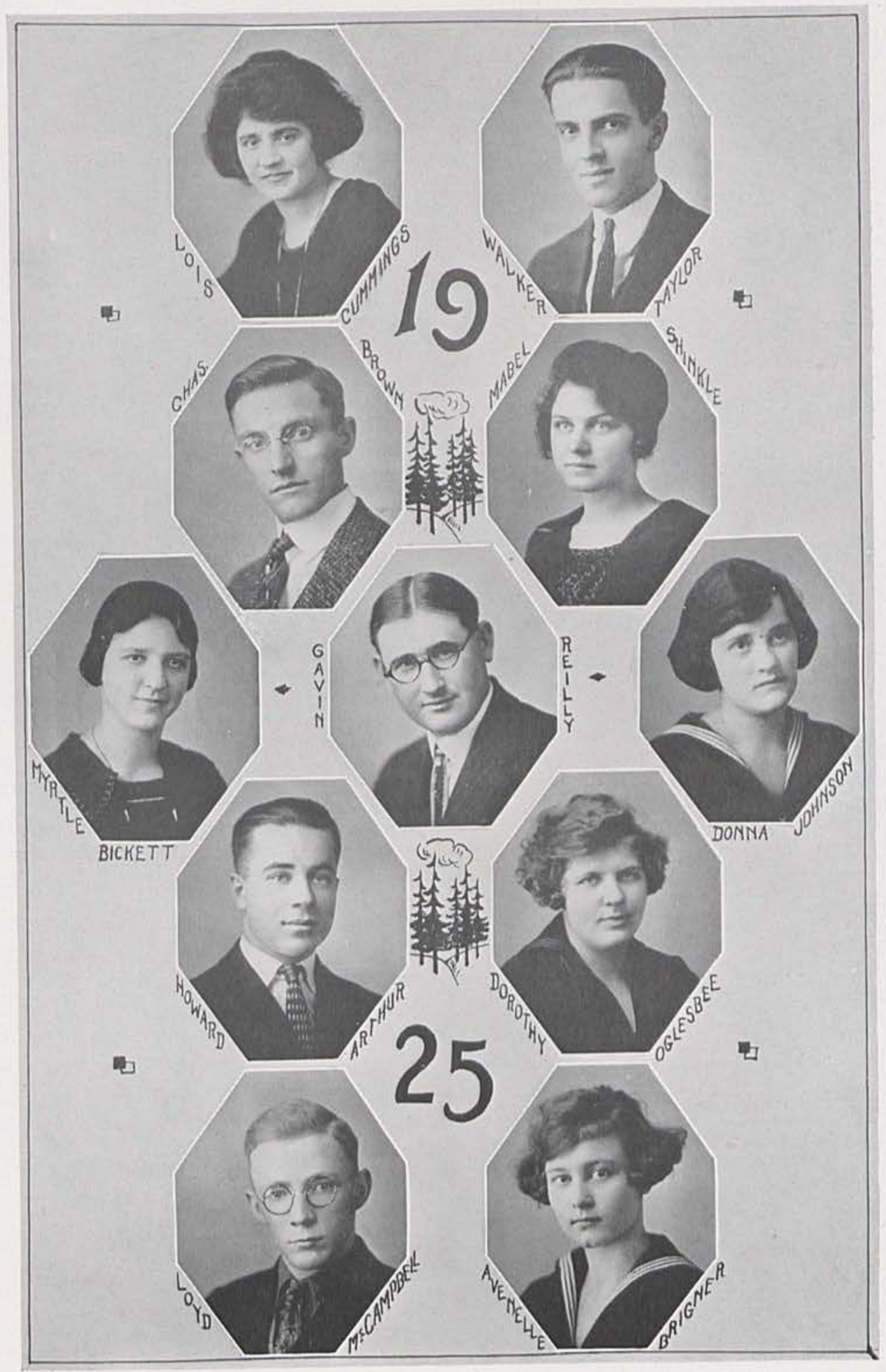




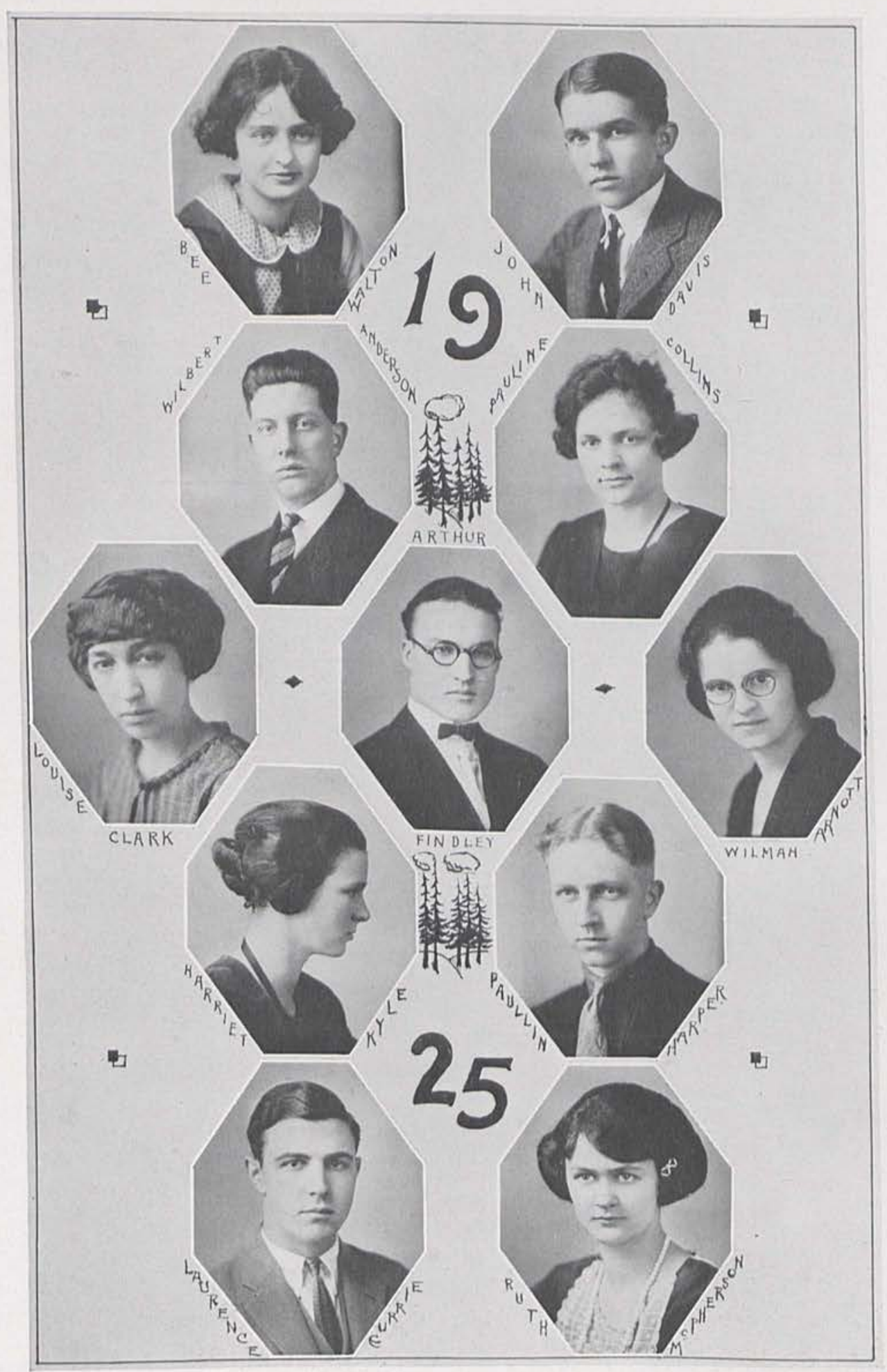



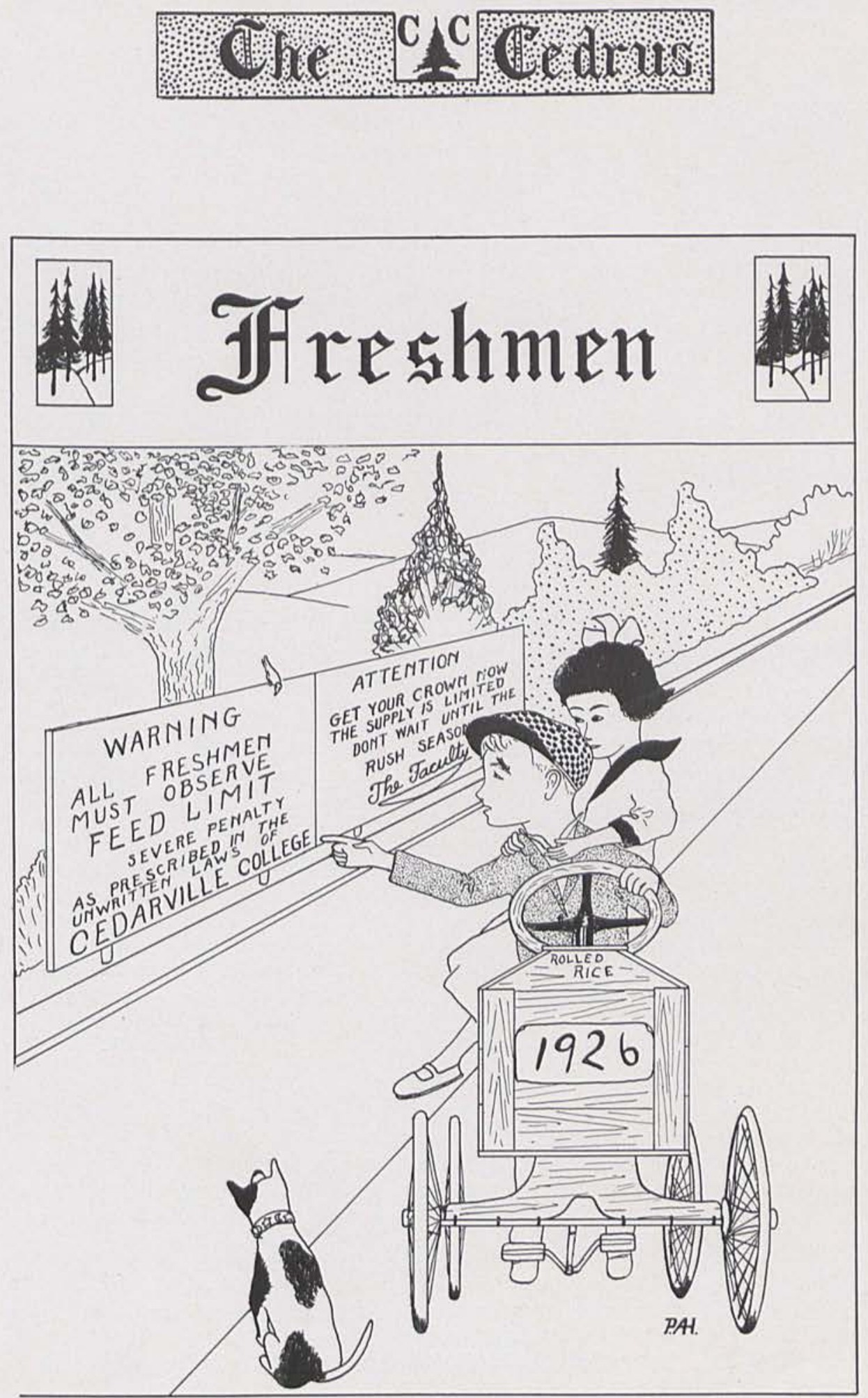

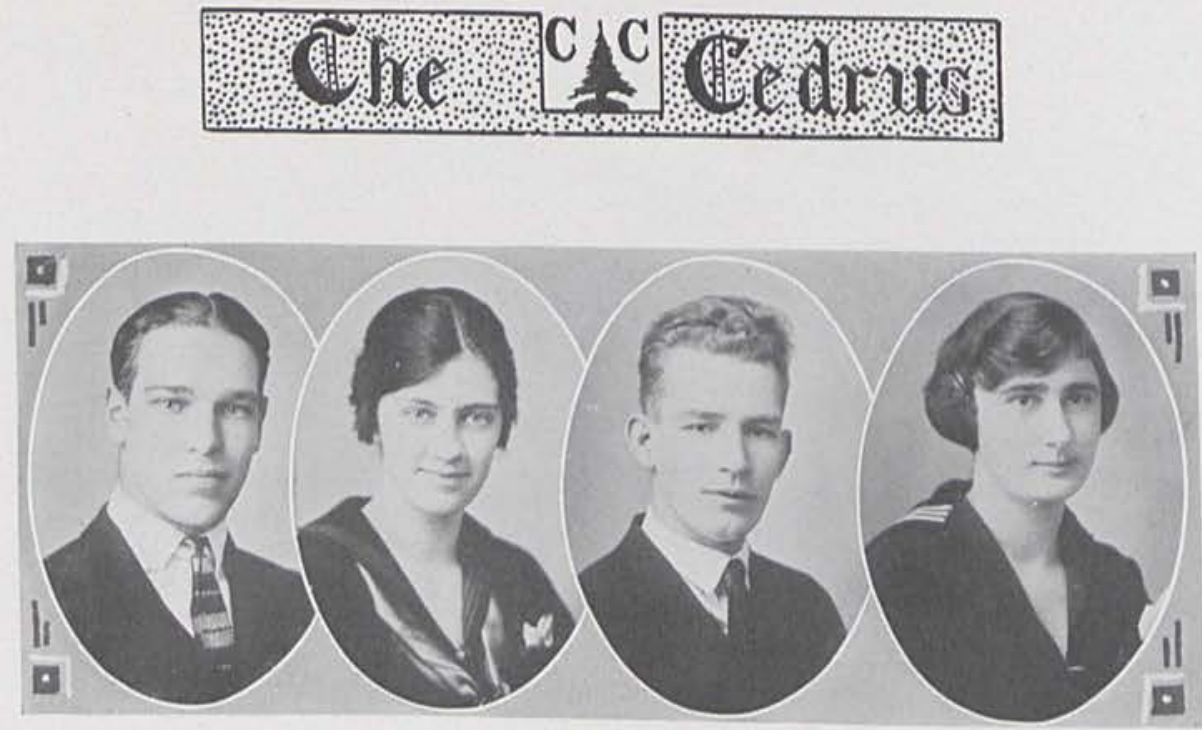

President, Paul EdWards

Vice-President, HENRY KYLE

Secretary, June THompson

Treasurer, ClaRA ELDER

\section{FRESHMAN CLASS HISTORY}

The Class of 1926 was born on September 13, 1922. It learned to walk the first day; in fact it could walk before it could express itself very fluently in words. "Ma" Alma Mater and "Pop" Faculty were very proud of the new-comer, (especially at first) and, personally, we don't blame them; the Freshmen certainly did make a bright, if somewhat colorful, appearance. They "got together" on September 20, and formulated a very popular form of amusement in Cedarville, known as a "feed." This was held at Dorothy Tarr's, and everyone, including some Sophomores, enjoyed it.

On December 7, the Faculty decided that the Freshies could go no longer without some form of organized rule, even if it had to be mob rule. As rulers, the following mob was chosen, (do not worry, gentle reader, the writers are now too far away to be in danger). President, Paul Edwards; Vice-President, Henry Kyle; Secretary, June Thompson; and Treasurer, Clara Edler.

The Freshmen have been extremely active in athletics, furnishing about half of the football and basketball squads. The outlook for baseball is also very good.

As in all classes, some like to study, and some don't. As an average, however, the writers feel safe in saying that we are far above the records set by any previous Freshmen class, even the illustrious (?) present Senior class.

As individuals, we are merely cheerful, healthful, happy young men and women, ready to look anything in the eyes.

Unlike most beings, we possess supernatural knowledge, we know when we are to die! This interesting event will probably take place June 8,1923 . There will be a host of mourners, for upon that day, three more of our number will cease to be: Brother Soph, Brother Junior, and Sister Senior! We wish 'em luck!

H. E. R.-G. M. P. 


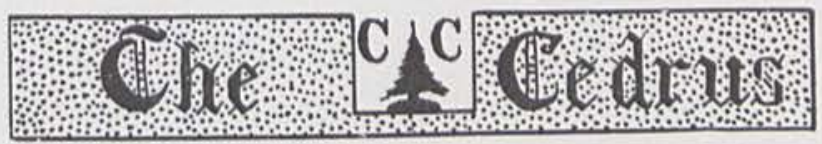

\section{THE BEST CLASS'S POEM}

On the hill beyond the river,

Opposite the township schoolhouse,

Stands the little red-brick college,

Where the pupils green, the Freshmen,

Gather to perform their duties.

Big Chief Edwards heads the council.

Next are Clara, June, and Henry,

Who make rules and take the money.

Bowyer, champion pigskin passer;

Dovel, rivaling Valentino;

Glass and Johnson, jovial room-mates;

Hunt, who does not take things serious;

Martha Beam, rotund and jolly;

Dickey Cooper, little shaver;

Hastings, Dobbins, Mills, and Strobridge,

Tarr and Anderson and Jurkat,

From the school across the roadway;

Gerren, from the Keystone country;

Plummer, Hutchison, and Ater,

Studious and unassuming;

Harbison, Outram, and Cowgill,

Silent, shy, but thinking deeply;

Pete, who parks down on the Av'nue;

Ray, a boy with high ambitions;

Peters, caring naught for roll-call;

Morrison, from colder regions;

Nagley, player of the tom-tom;

Two Smith boys, though no relation

To the ones who make the cough-drops;

White, who journeys from the Corn State;

Hopper, ardent basket-baller;

Betty, Chevrolet admirer;

Murphy, talented musician;

Crowell and Burbick, youngster members;

Edna Collins, stately student;

Mary Aggie, ever happy;

Meahl and Spracklen, Stuckey, Louis,

Make the list of girls completed;

Pierson, earnest, quiet, friendly;

Funk, who has a sense of humor;

Walker, from the Armco city,

Now complete the tribe of Freshmen-

Freshmen, starting in last autumn

To the little red-brick college

Opposite the township schoolhouse

On the hill beyond the river.

"YANK" JURKAT. 


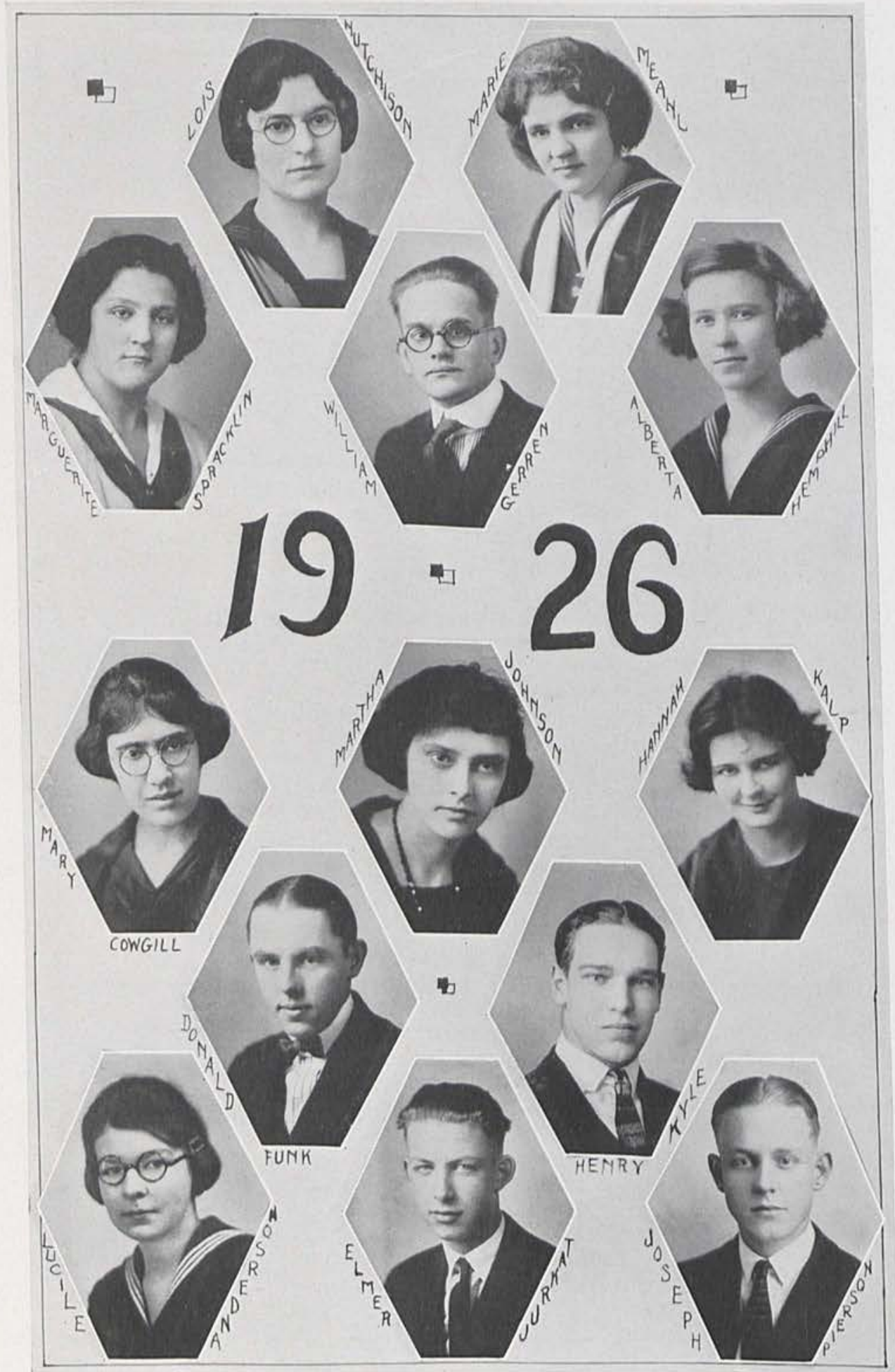




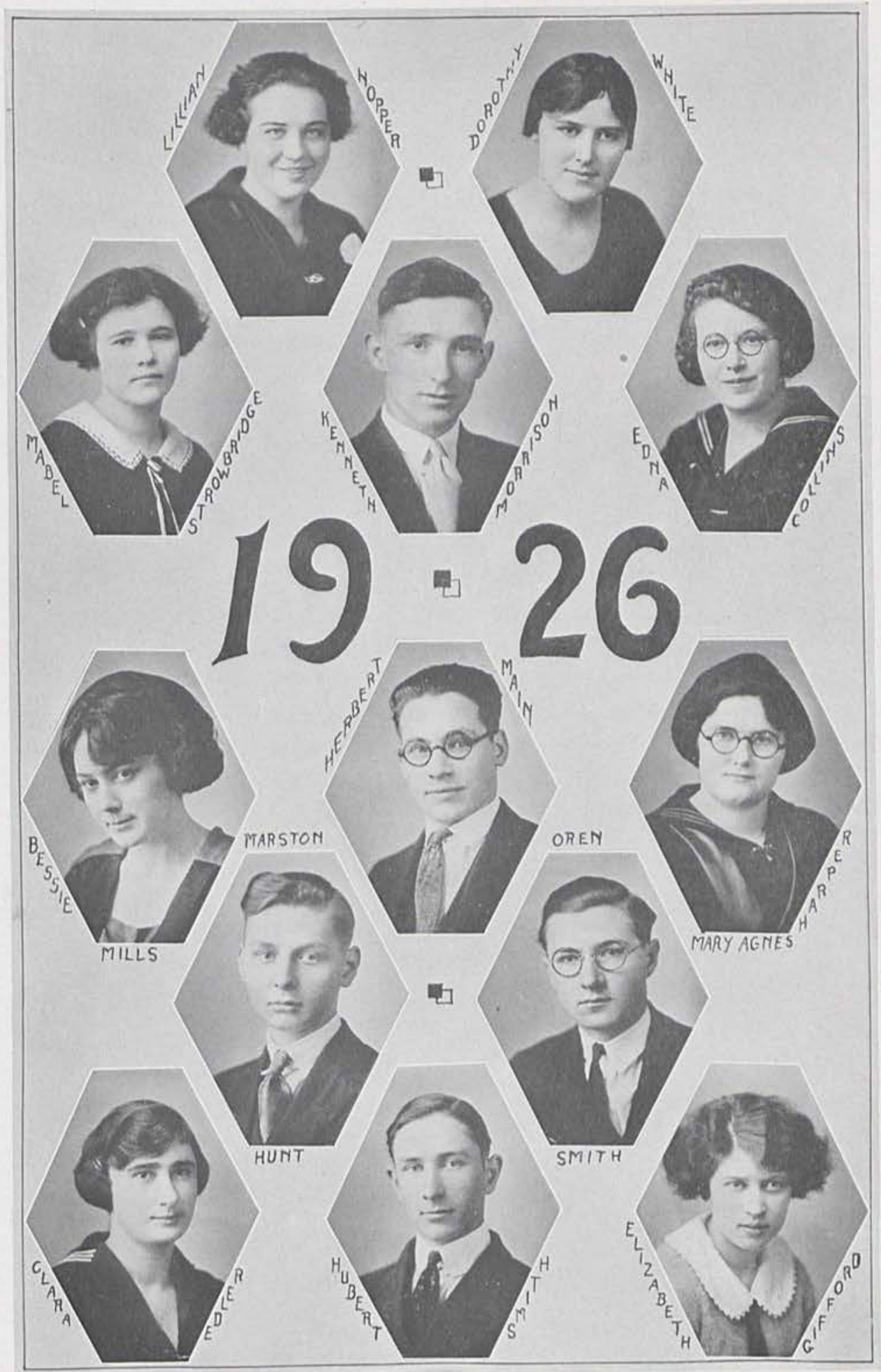




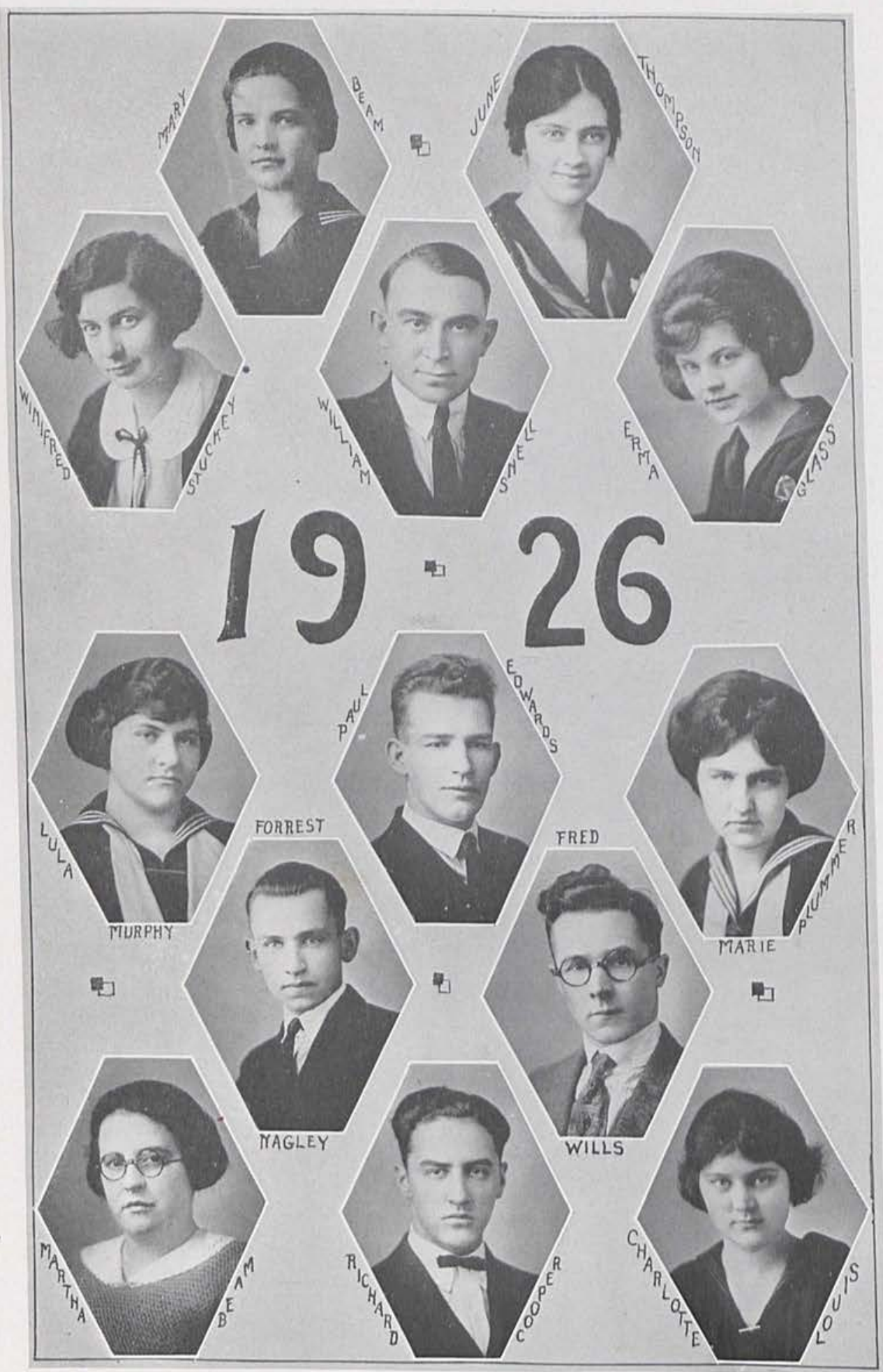



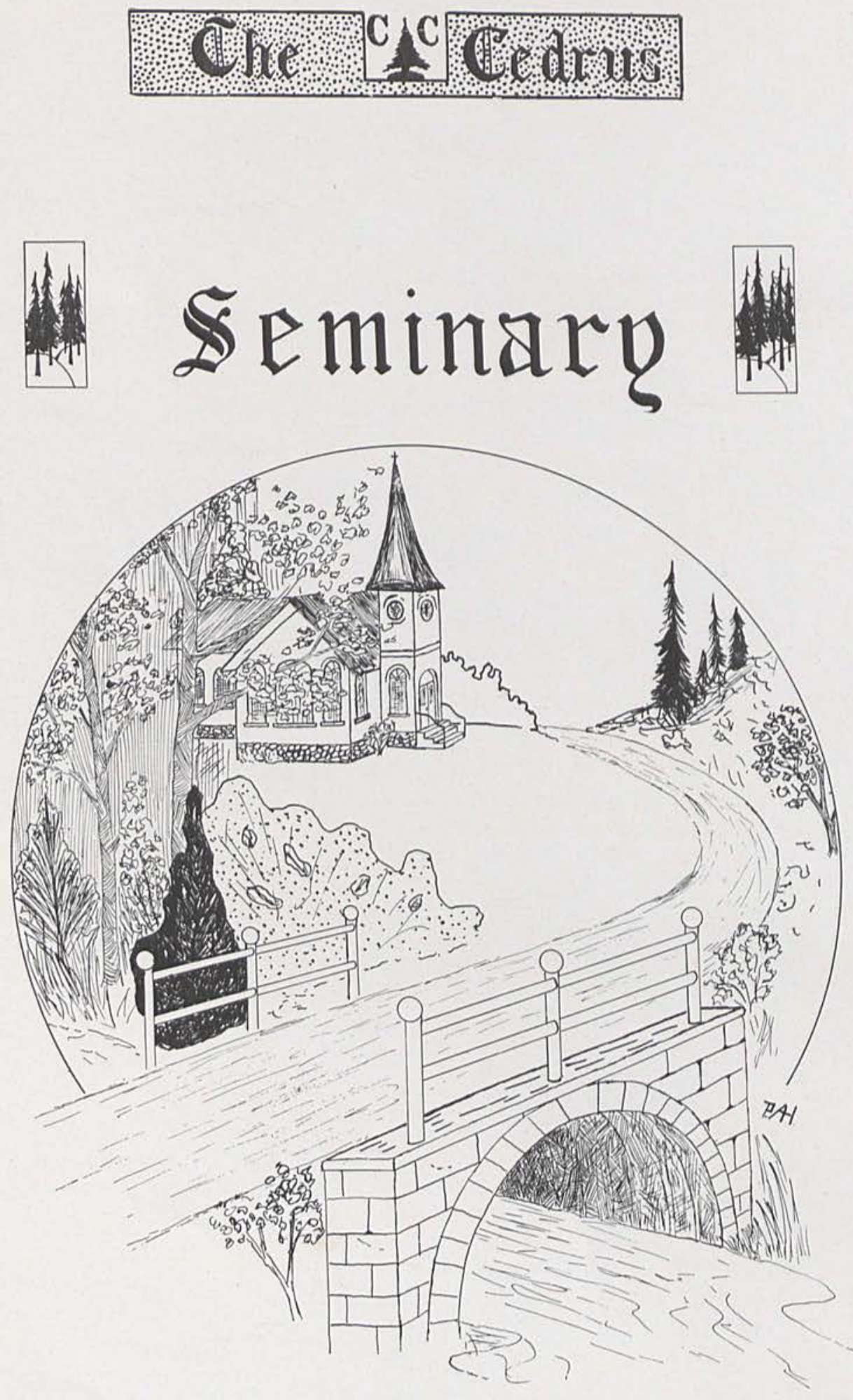


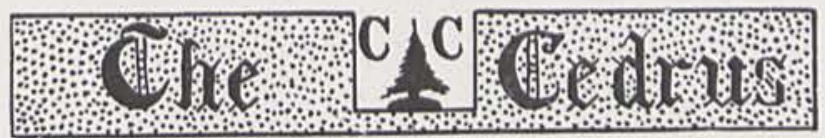

\section{SEMINARY}

The Reformed Presbyterian Seminary, operating in conjunction with Cedarville College since 1913, opened in September with an enrollment of six students. Two more, taking partial courses, joining at the beginning of the second semester brings the total to eight.

As usual, various denominations are represented in the enrollment, the advancement of Christ's Kingdom being always considered before that of "our church."

The presence of the Seminary is a great aid to the moral and spiritual life of the College, and, while far from monopolizing religious leadership, the students of the Seminary stand as willing auxiliaries to all who are working for right and righteousness. While they are not free from many faults that are common to college students, they are with scarcely an exception, true at heart.

The work of the Seminary is felt not only in the college and town, but also in the surrounding community where many of the students are employed in Bible teaching, preaching and mission work.

At present the teaching force consists of the following: Rev. Wilbert R. McChesney, A.M., Ph.D., D.D., President of the College and Dean of the Seminary; Rev. F. A. Jurkat, LL.D.; Rev. W. P. Harriman and Rev. B. E. Robison, B.D. The last two named are new members on the teaching force since last year.

These men rank high in their qualifications as Seminary instructors. Dr. McChesney is apt, brilliant and scholarly; a man of wide and deep experiences. He is especially fitted as leader and counselor of the young men who are looking forward to Christian service, because of his consecrated life, plus an experience rich in the fruits of actual contact with college life for more than a quarter of a century. Rev. Jurkat is a gifted man of equal experience and represents a different type of Christian, but one no less consecrated and sincere. Rev. Harriman is pastor of the local Reformed Presbyterian Church and a strong Christian man, one who has made good in his particular field and is now ready to lend a helping hand to those who have like ambitions for service. While we regret very much to note that our beloved Professor Allen is no longer with us, we are on the other hand glad to announce that in his place we have Rev. Robison, who is a worthy successor of a worthy man. Mr. Robison possesses an unusual range of experience, having been long an active worker, under varied conditions, in both the home and foreign mission fields. Although not a member of the Reformed Presbyterian denomination his life and teachings commend him to all who have the mind of Christ.

Under the instruction of men possessing such varied experiences and high ideals, no young person need graduate with a narrow or onesided conception of right and service.

I. S. W. 

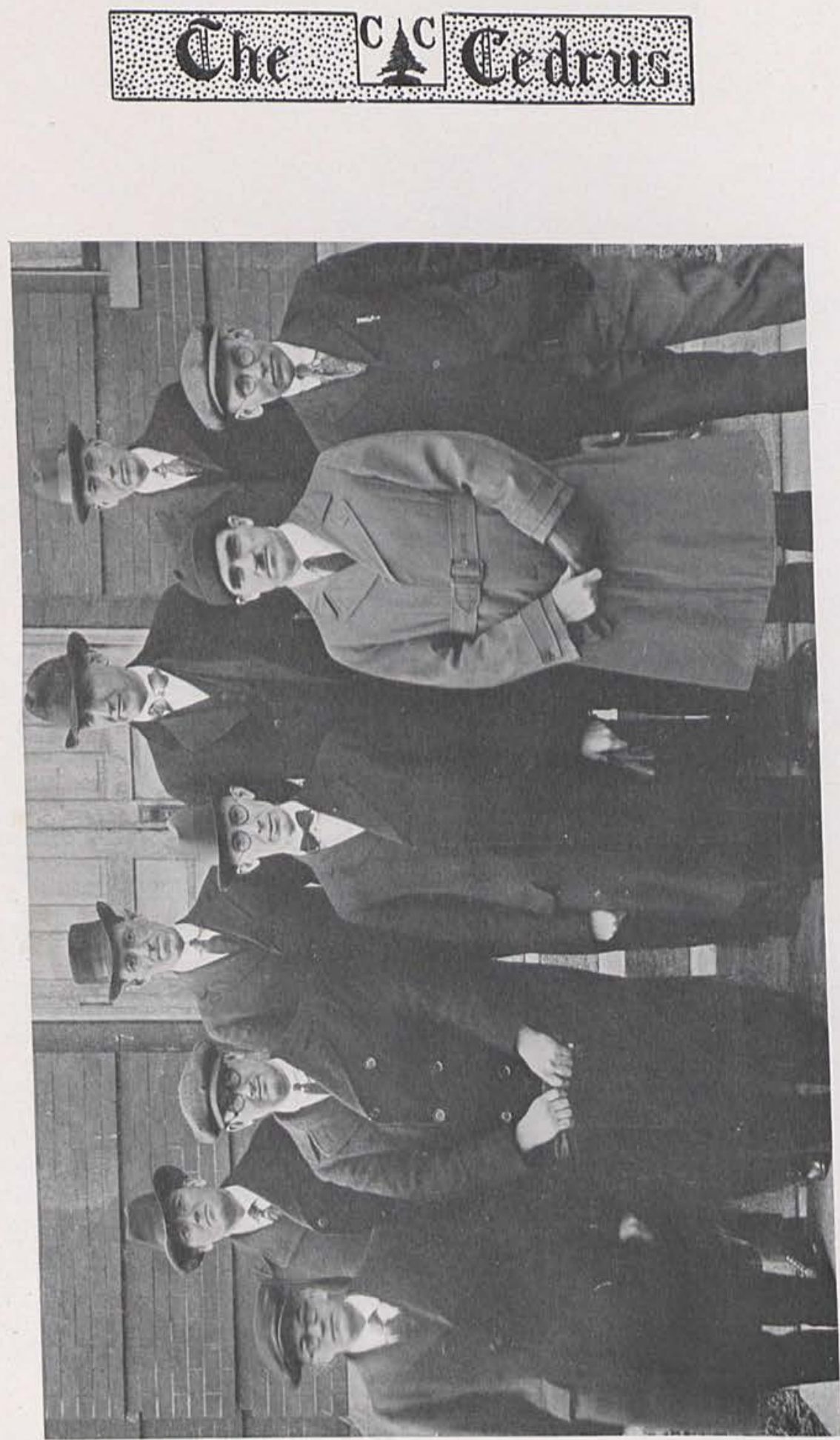


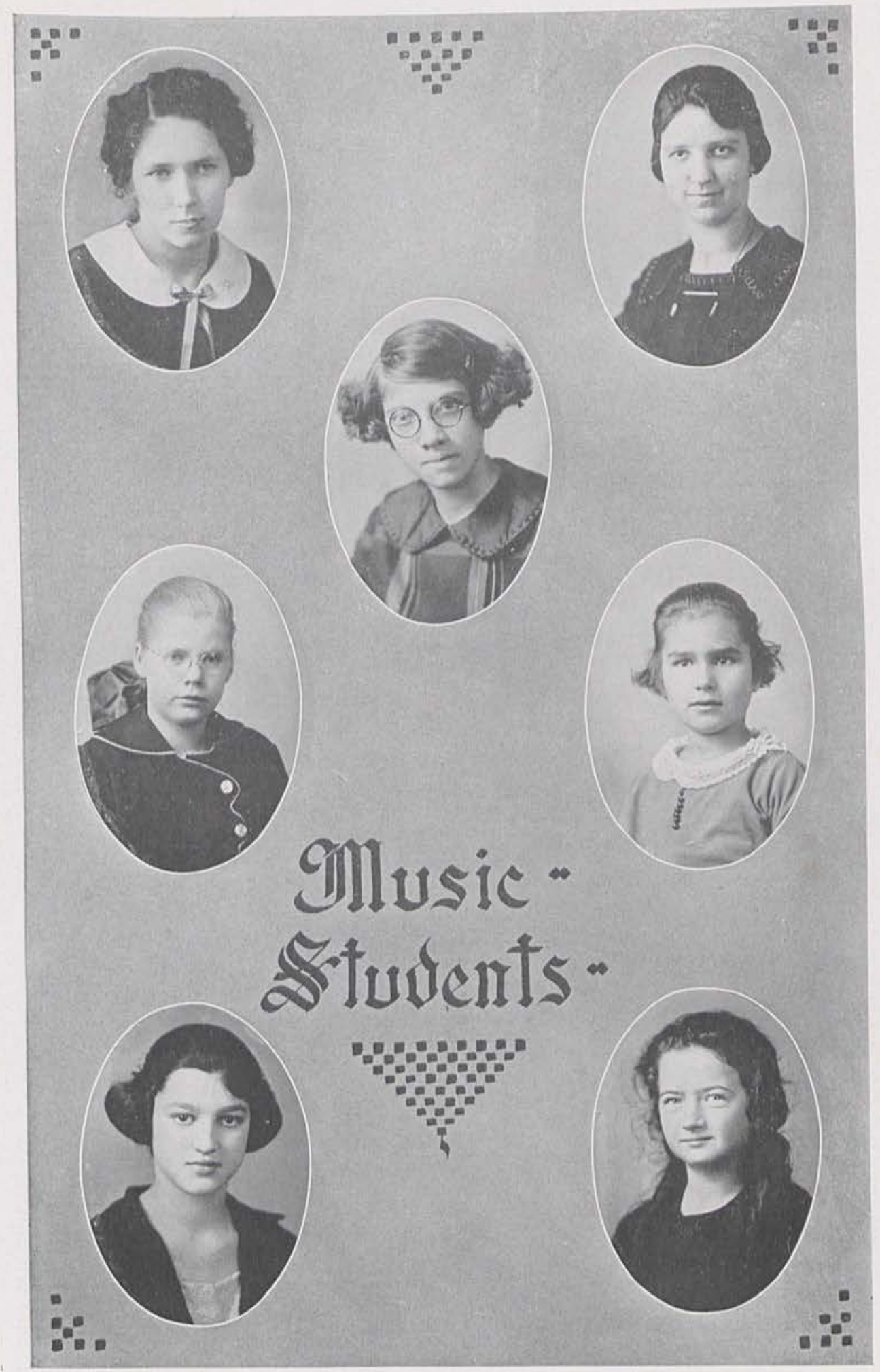




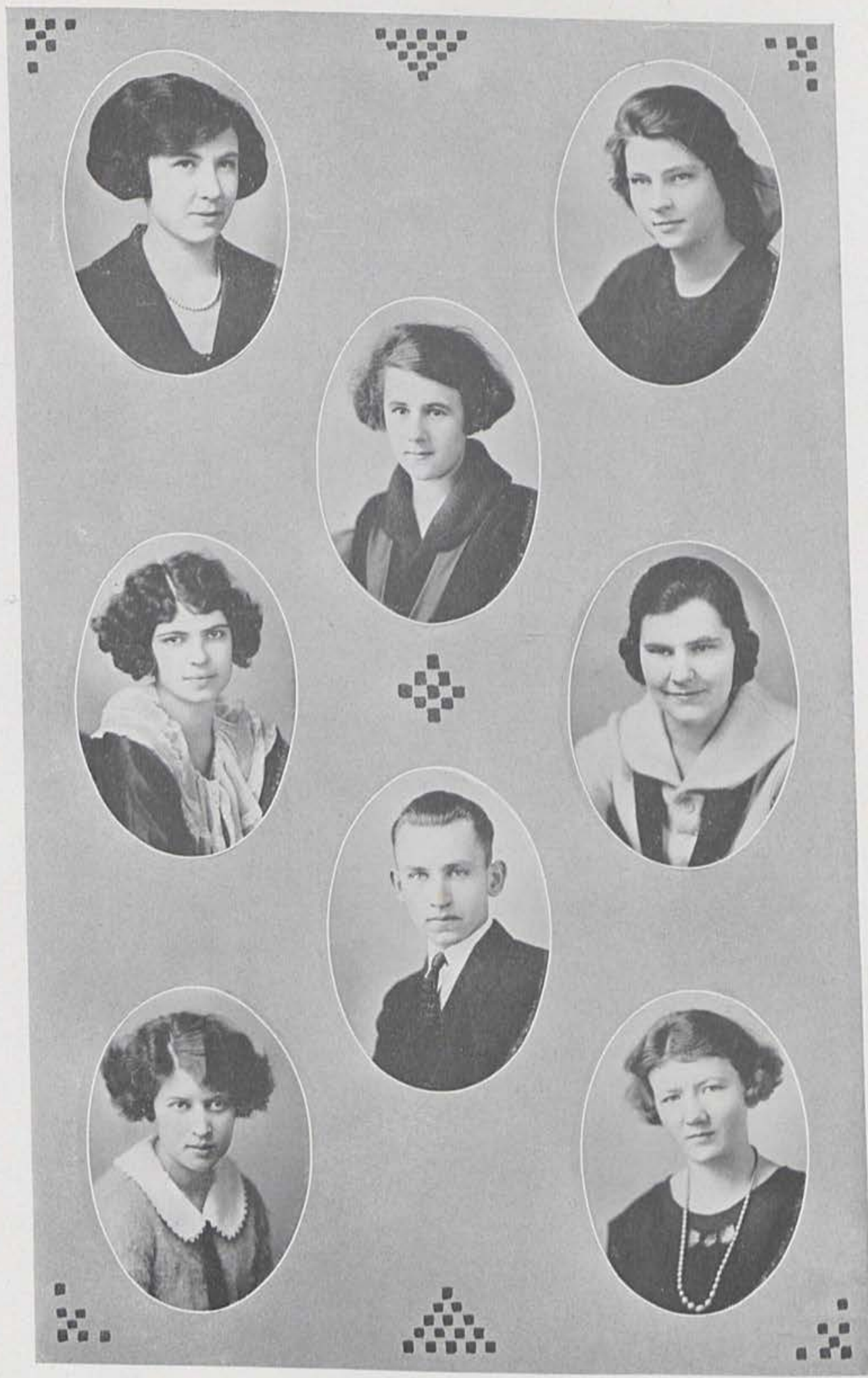




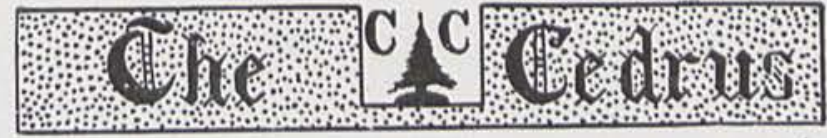

BOOK IV - . ATHLETICS
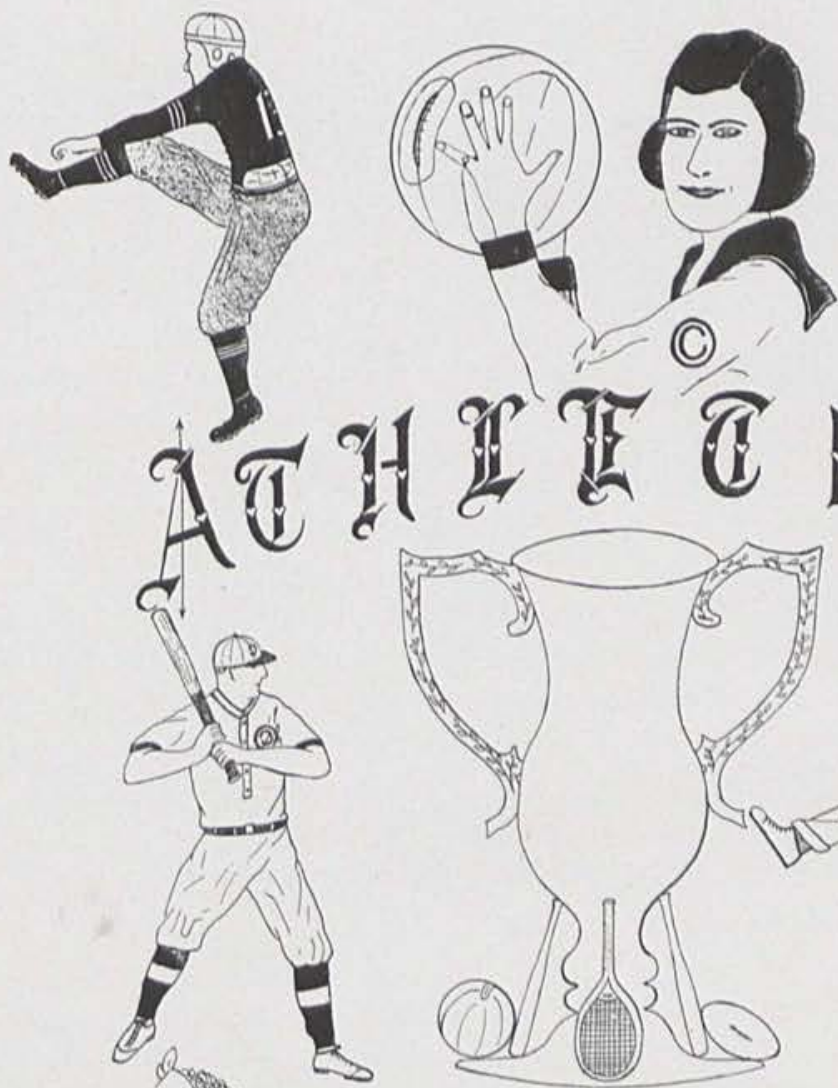

(ल) $(20)$

2. 3
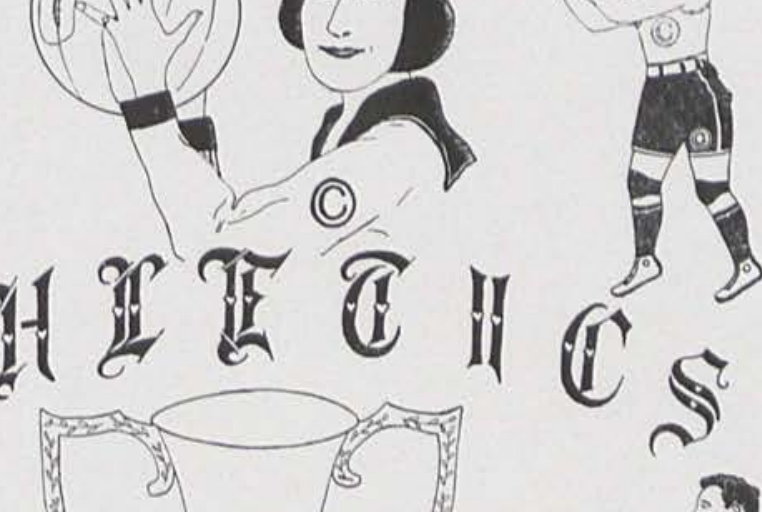

are
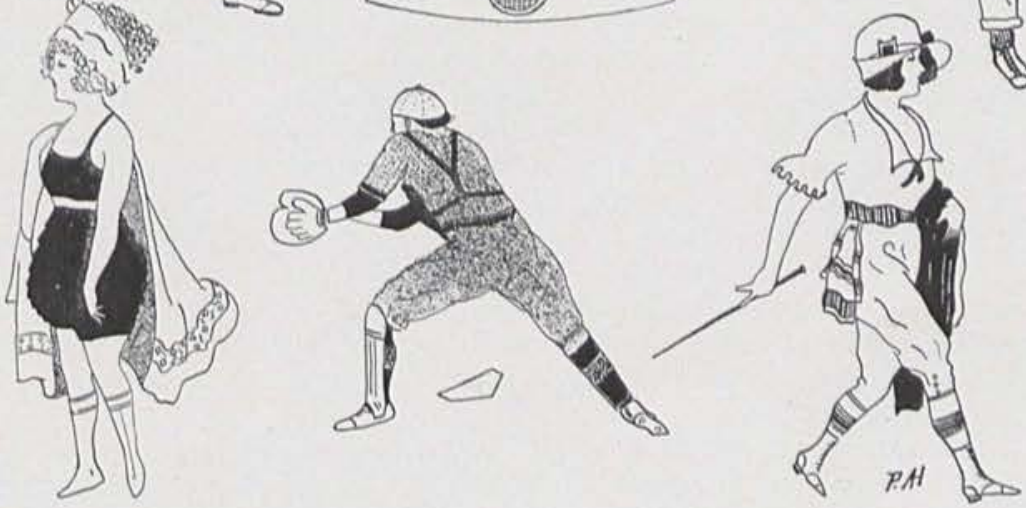


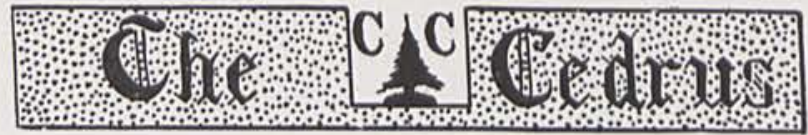

\section{GRIDIRON NOTES FOR 1922}

The efforts put forth by our former Coach, Blackburn, to develop a football team worthy of the name, were well worthwhile and the training he gave the footballers last season proved a valuable asset to the gridiron squad of 1922 .

Soon after the College doors were open in September, "Pop" Warner, our new Coach broadcasted the call for gridiron candidates to meet at Alford Memorial Gymnasium, there to receive uniforms and report for the first practice.

Then the grilling practices began at once. Coach Warner realized that he must whip his gridiron warriors into condition hurriedly, owing to the fact that our first game, which promised to be a hard fight, was less than three weeks away.

Coach Warner (early in the season called "Pop") began at once to instill the old pep and fighting spirit into the squad.

The first game of the season was played with Dayton University, at Dayton, Ohio. In this game Cedarville was completely outclassed as can readily be seen by the score of 59-0. However this was the best team we met this season and was considered by football fans to be one of the first-class collegiate teams of the state.

The next game was played a week later with our old rivals, "Antioch," at Yellow Springs, Ohio. In this game the team was handicapped considerably because of injuries received in the Dayton " $U$ " game. The game was exciting the first half, the score being $0-0$. Then Antioch slipped over 6 points in the third session, and in the final period they scored 13 more and Cedarville lost to the tune of $19-0$.

The third game of the season was played with Rio Grande on the home gridiron. In this game the score was $6-0$ at the end of the third quarter and the home team was defeated again by a score of 19-0. This score was not at all satisfactory to the old C. C. grid warriors but it was quite an improvement over last year's score with Rio Grande which was more than twice 19.

The fourth game of the season was played on the home field again, with Defiance College, of Defiance, Ohio. Defiance had a strong bunch of warriors and although we lost to them, the score being $18-0$, we were not discouraged because the score was less than half that of the previous season.

Cedarville played the last game at home and closed the season with a fitting climax by winning a decisive victory over Antioch. The score was 16-0. In this game Cedarville took an early lead and scored in the first, third, and fourth periods, completely outclassing the visiting team. Antioch made but one first down in the entire game and crossed the 50-yard line but once and then it was for a small gain of two yards.

In general the brand of football played this year was an improvement over last year's efforts. Last year's experience improved several members of the squad, and the additions to the squad this year were also a valuable asset.

Coach Warner is deserving of much credit for the improvement in the team, and his earnest and efficient efforts together with his loyal devotion is appreciated by each member of the "squad."

The next season promises to be a hard but interesting one with games scheduled with Ashland College, Ashland, Ohio; Marshall College, Huntington, W. Va.; Defiance College, Defiance, Ohio; Rio Grande, at Gallipolis, Ohio, and also with our neighboring college and old rival, Antioch.

Let's boost for a successful season in 1924 . 

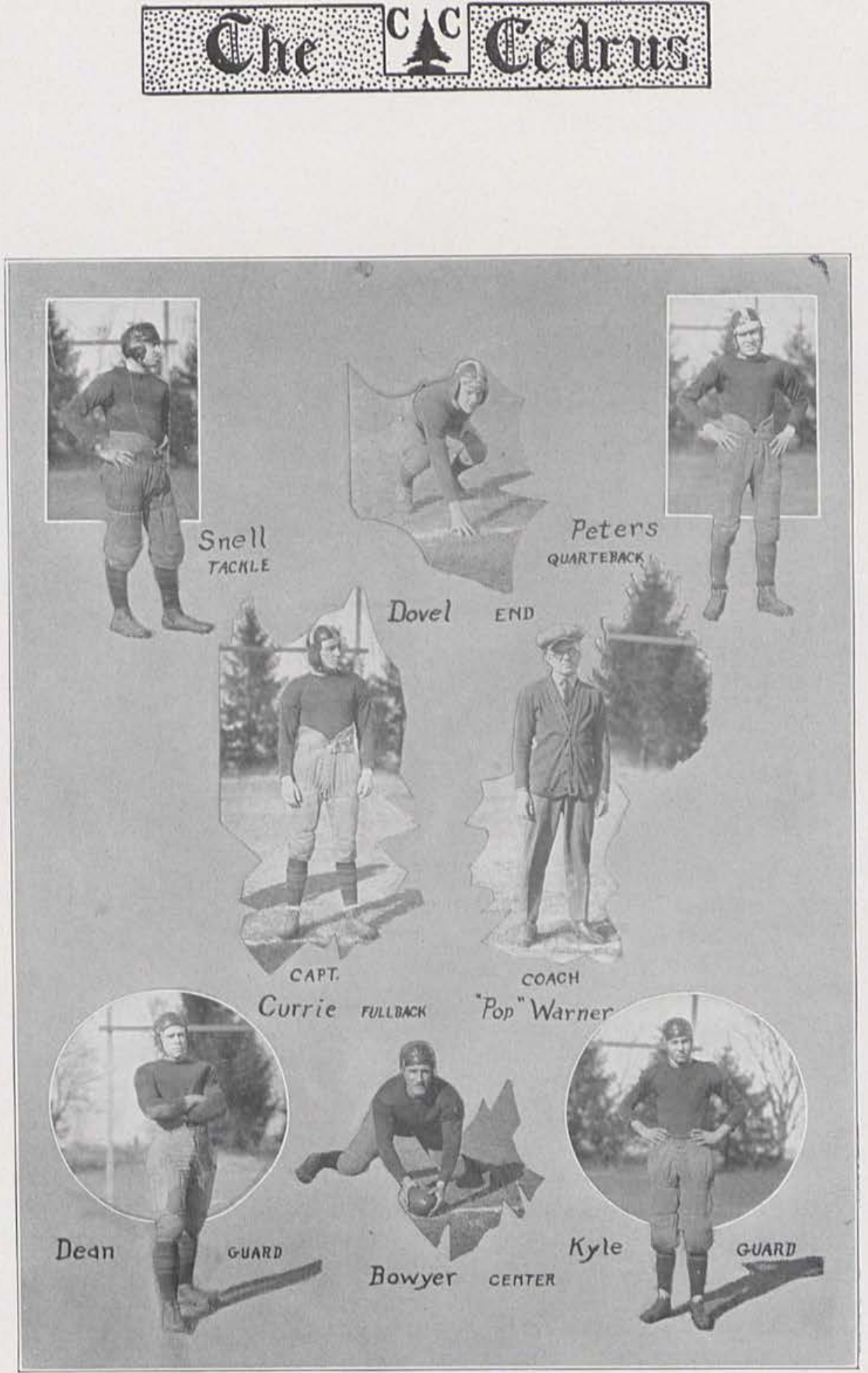

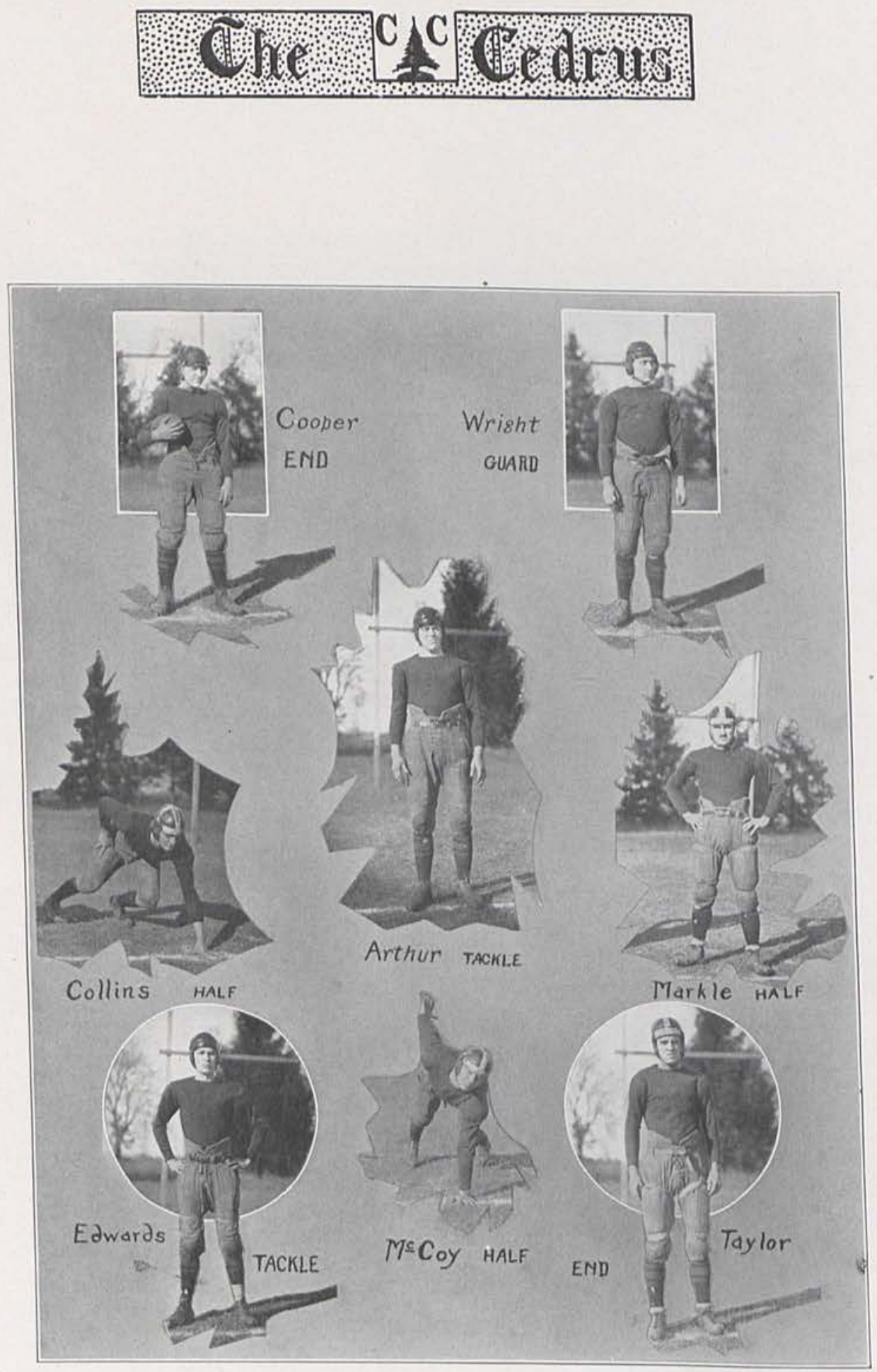

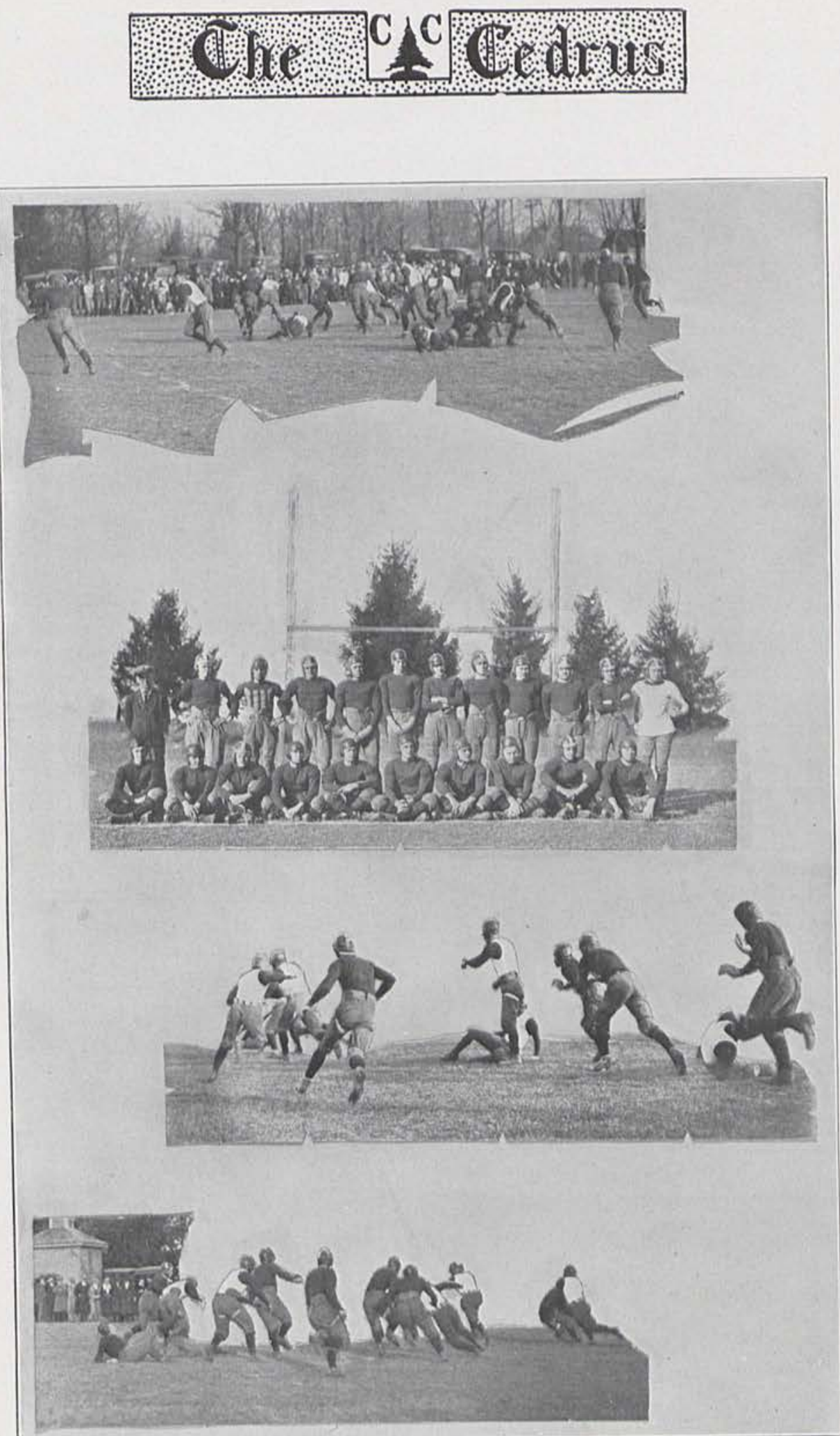


\section{BASKET BALL}

One week after the closing of the foot ball season the call for basket ball was sounded. Some twenty-five or thirty men responded, and the early days were spent in hard drill and practice.

The players left from the previous season were: Taylor, Currie, Collins, Davis, Arthur, Wright, Wickerham, and Markle. Though the season of last year was not a success, the men left were to be re-vamped into a successful and spirited team. "Pop" Warner had a real job in turning this group from an individual team into one of great team play, and he succeeded in wonderful style.

Though the season opened with two defeats at the hands of the Willis Business College, of Springfield, and the Boring-Yanks, of Xenia, the team did not lose spirit but profited by mistakes and came back strong. The third game was a victory over the Ohio Mechanies Institute, of Cincinnati, and the fourth was also a victory. The Omega Tau Psi Fraternity, of Springfield, were defeated.

The two following games were lost to the Sabina Independents in an overtime engagement, and to our greatest rival, Antioch. Both games were of a high calibre but we were hardly in true form.

A trip to Cincinnati resulted in two victories for Cedarville. The Cincinnati Gym was defeated, and the Ohio Mechanics Institute fell for the second time at the hands of Cedarville. Our team displayed real playing ability in these two games and old Cedarville was proud. As though to take all the joy out of life, we were again defeated by Antioch. Our boys were not up to form and all luck seemed to be against us. We then won a game from the Boring-Yanks and all was right again.

The last game of the season was with the Ohio Northern University. This was one of the best games ever played by the Cedarville College team. The Northern toam, though much larger and seasoned, was held to 15 to 15 tie during the first half. In the second half our opponents were able to better us and we were defeated though not depressed. Great spirit was displayed throughout the game and the team fought hard to the end.

The season as a whole was a success compared with previous standings in late years. The varsity and the substitutes, who deserve a great deal of credit, are congratulated upon their success in the effort to bring our record to a higher standing.
The games and scores are as follows:

Cedarville 25

Cedarville 21

Cedarville 42

Cedarville 22

Cedarville 42

Cedarville 15

Cedarville 14

Cedarville 27

Cedarville 29

Cedarville 14

Cedarville 22

Willis Business College 38-At Home Boring-Yanks 22-At Xenia Ohio Mechanics Institute 20-At Home Boring-Yanks 20-At Home Omega Tau Psi 13-At Home Sabina 17-At Sabina Antioch 27-At Antioch Cincinnati Gym 15-At Cincinnati

Total 273 Institute 12-At Cincinnat Antioch 31-At Home Ohio Northern 38-At Home

Total 253

"Pete." 

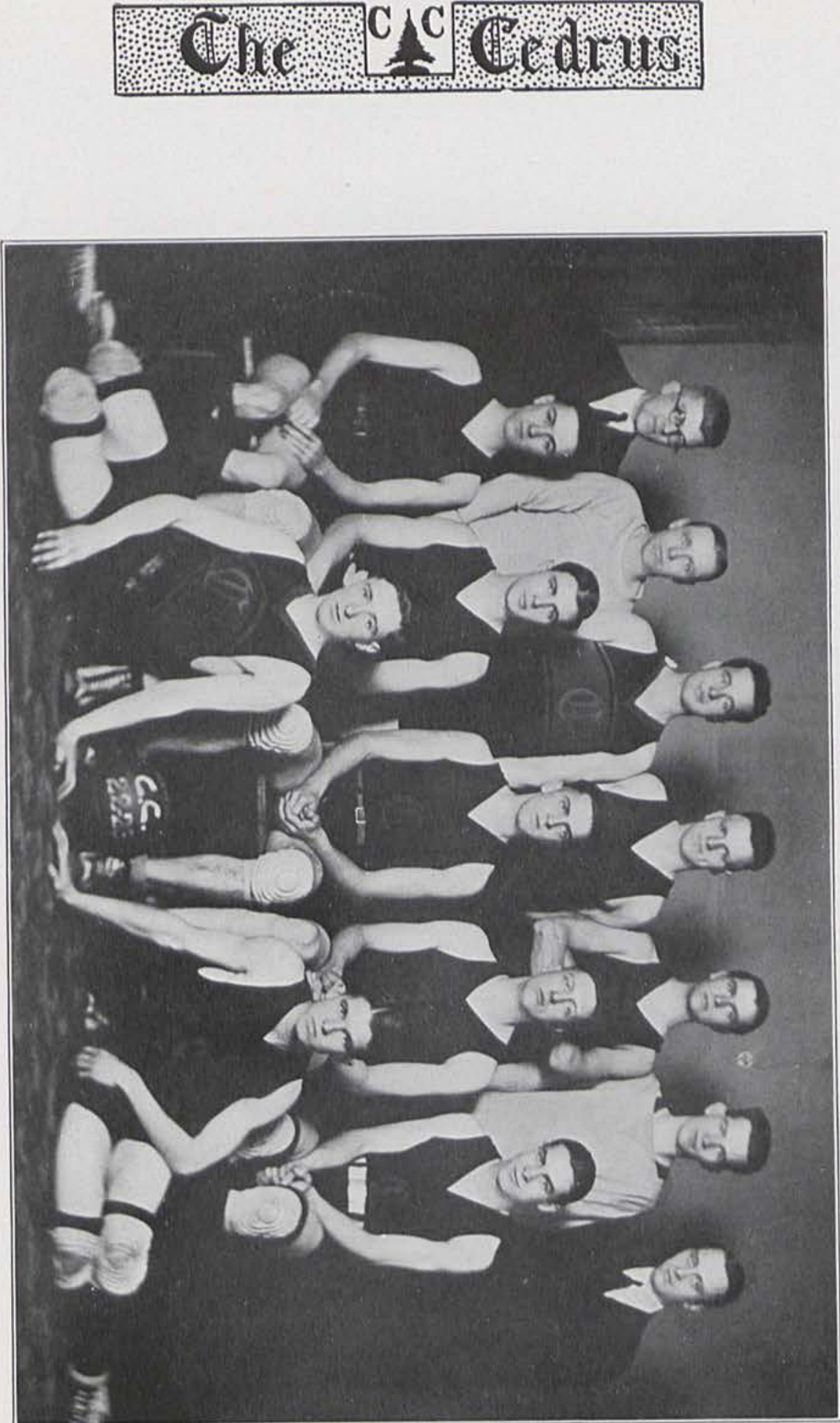


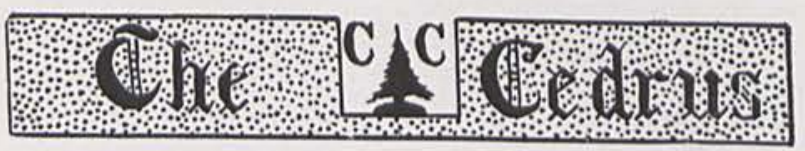

\section{GIRLS' BASKET BALL SEASON}

Basket ball fans of Cedarville and vicinity open their eyes when they see an advertisement of a Cedarville girls' game. Why? Because they always appreciate a good clean game and know what they like to see will be their privilege. We don't feel a bit egotistical when we say we think we have the best playing and best looking team to be found anywhere and I'm sure you will all agree, especially when you see them all "dolled up" in the new orange middies with which our college so kindly supplied them. Their looks do not surpass their athletic ability either for we boast a quick, speedy and winning team.

Through the persistent efforts of Coach Warner the girls' team has been one of Cedarville College's bright shining lights this year, playing eight games and losing only two-Nuf Sed.

It is useless to try to express our thanks to the team for the splendid work they did and to the college for the splendid backing they gave. So it is with great sorrow that we close our season this year for we realize what we will lose (in the way of basket ball players) when the Class of ' 23 leaves us. We wish you success and happiness whether it be in school teaching, in married life or more college work, and hope that some day we may have the privilege of seeing the team of ' 23 play again.

\section{B. GIFFORD.}

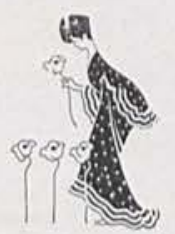



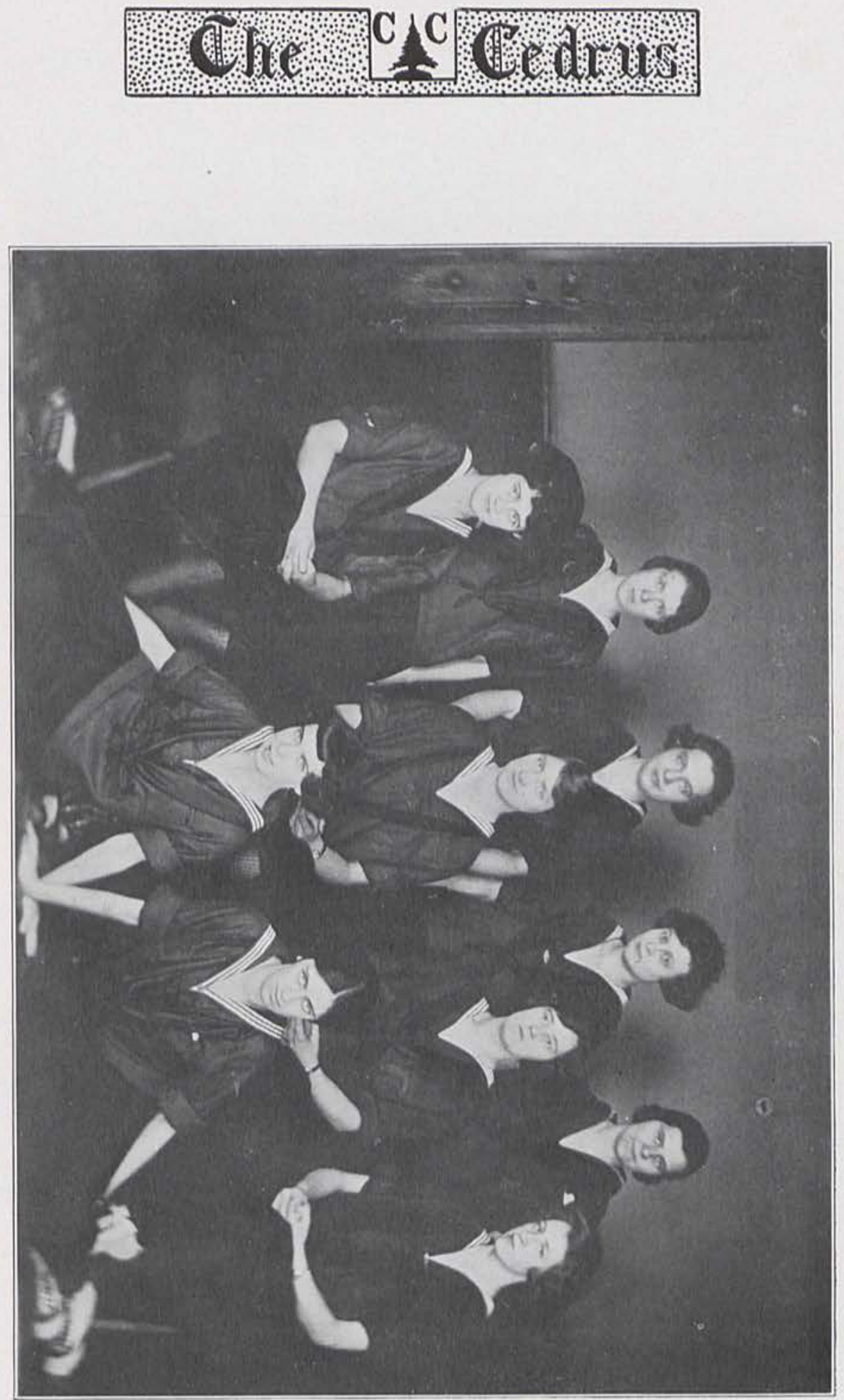


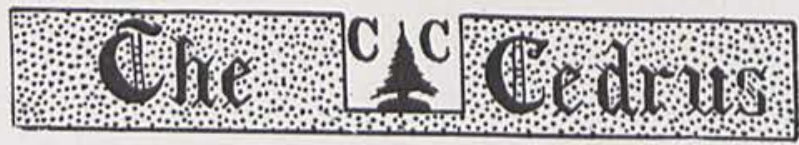

倠败

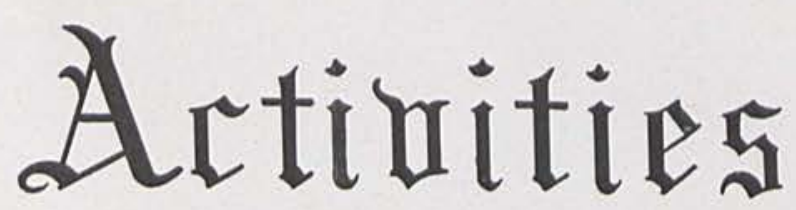
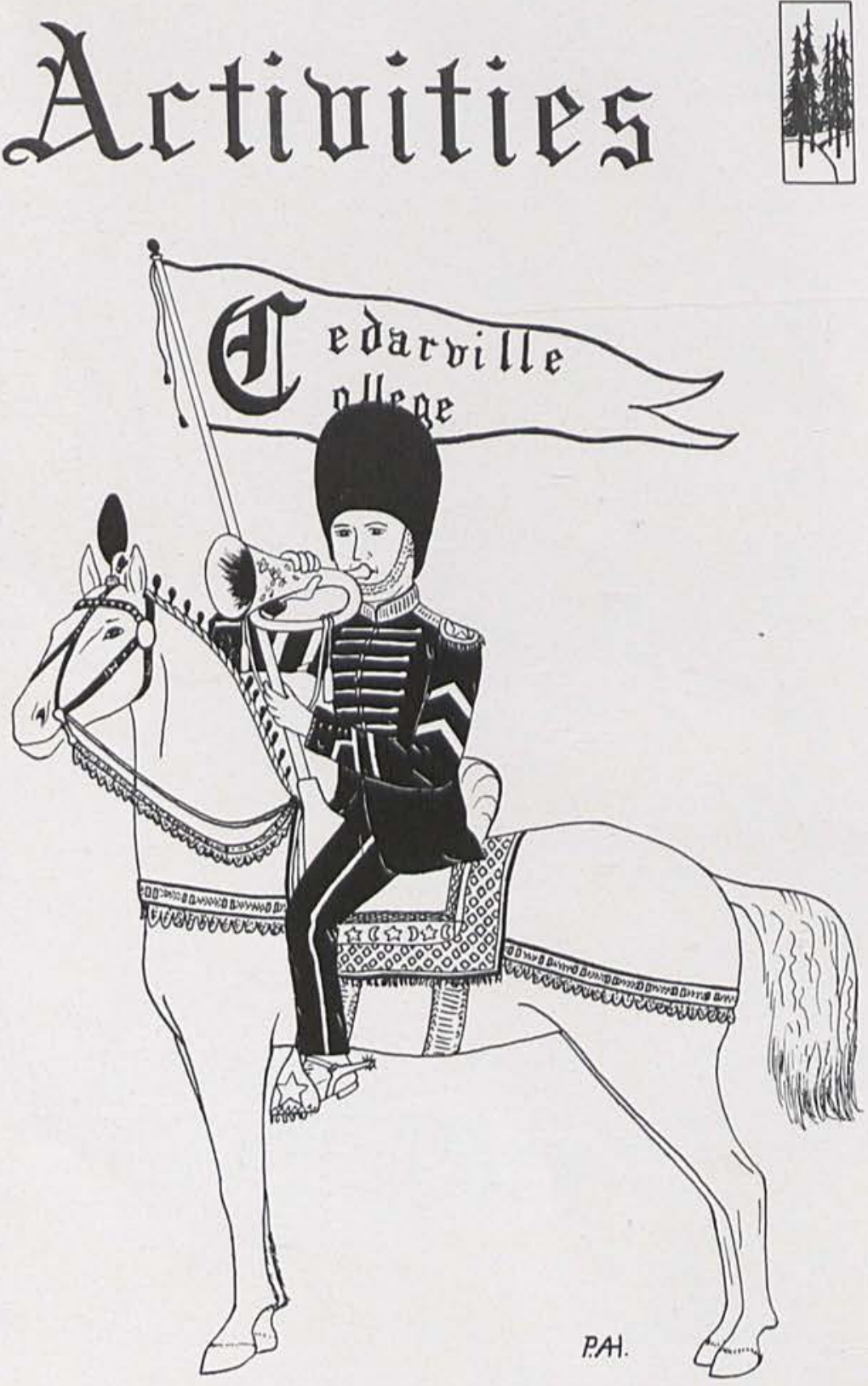

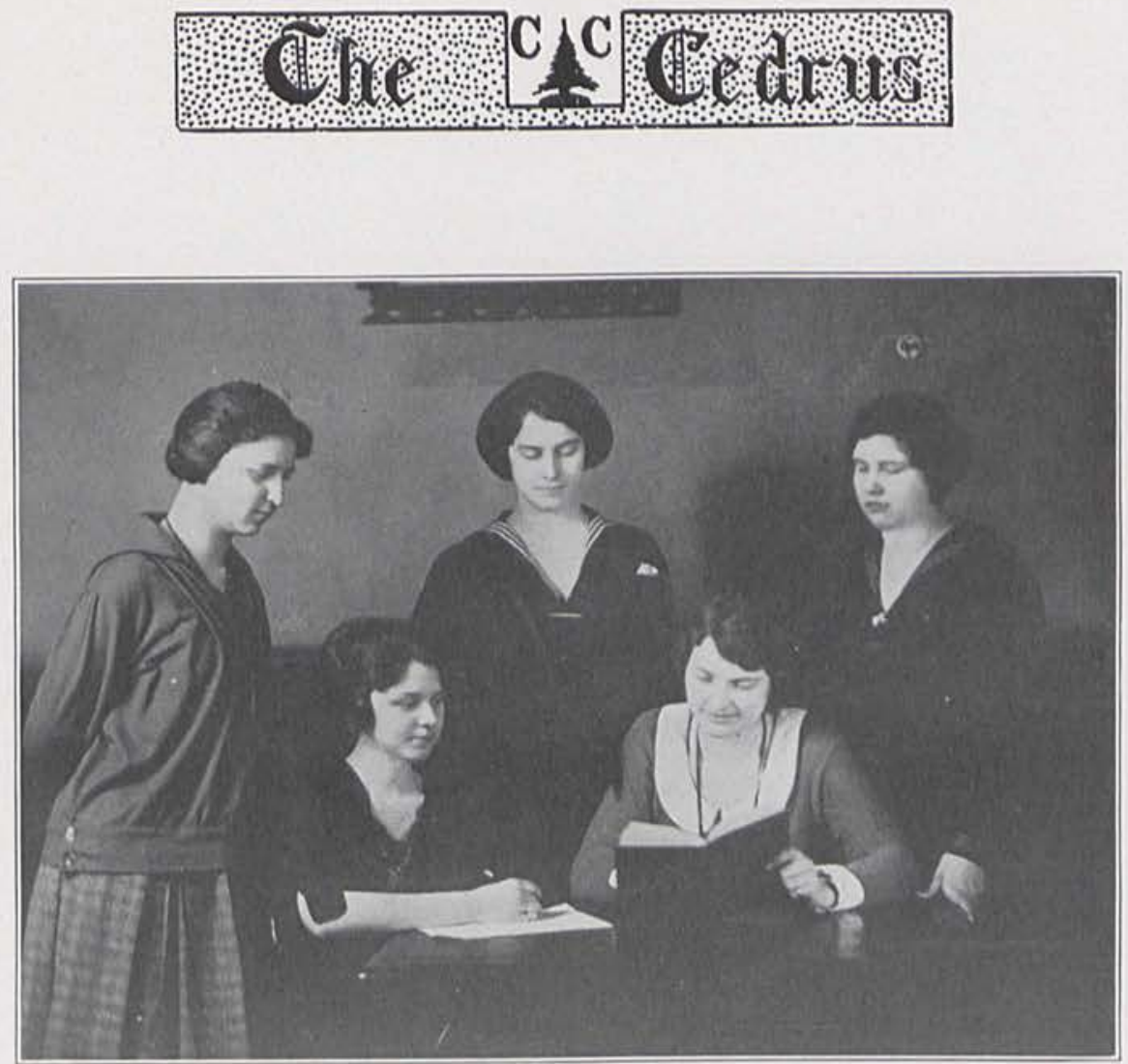

THE Y. W. C. A.

The Young Women's Christian Association was organized April 8, 1909, through the efforts of Miss Agnes Jean Smith, then Professor of English, and Miss Helen Sewall, Student Y. M. C. A. Secretary at that time. The membership then consisted of all the girls in college and at present a majority of the girls are members. Weekly meetings are held on Wednesday.

This year the organization has been very successful financially. Our greatest drive was election day, November 2, 1922. This we called Tag Day. The girls went downtown in groups selling tags to everyone they could see. We made about $\$ 100$.

This year we have attempted more work of a practical nature than we ever have before, and thus far have been successful. Ten Thanksgiving baskets were filled with all the bounties of the season, and distributed to all the needy of the village. The children of the poor families were remembered at Christmas with well-filled stockings.

We feel that our meetings have been very successful and interesting this year. We are especially pleased with the interest which the girls have taken in the work and the active part they have taken in our weekly meetings. Altogether we feel that we have a very bright outlook and that we will be able to accomplish greater things than ever in the future.

L. J. 

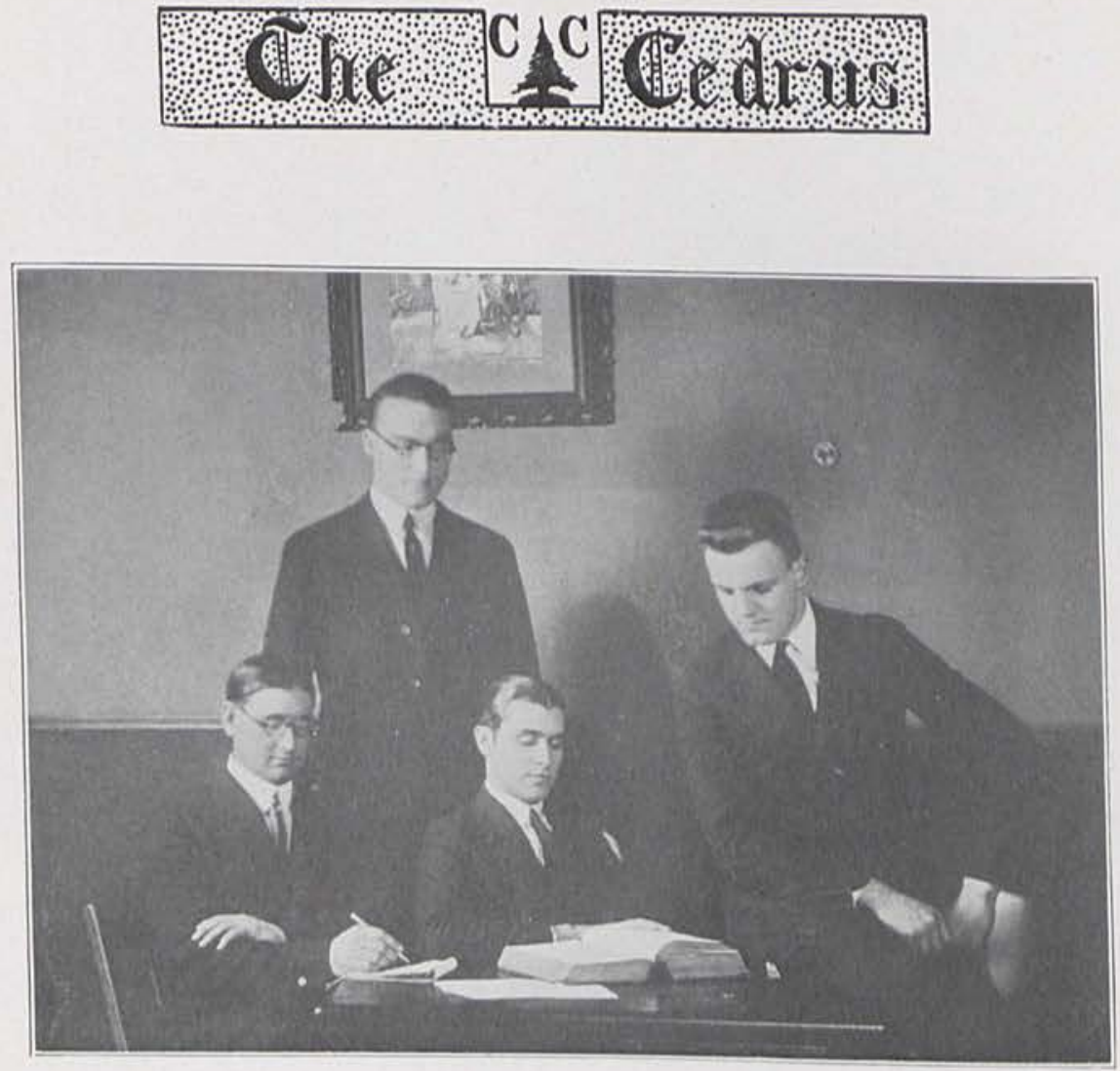

\section{CEDARVILLE COLLEGE Y. M. C. A.}

There are three phases to every college education, in order that it may be a true education, namely; the Spiritual, the Mental, and the Physical. The Y. M. C. A. helps to complete the spiritual life of every student, in fact it was with this idea in mind that the present organization began its career some seventeen years ago. Since that time the Y. M. C. A. has grown in numbers, in works, and in spiritual uplift for every student. Although the attendance at the meetings held every Wednesday morning is not compulsory, yet the most of the boys feel it a duty as well as a privilege to attend such inspiring and helpful meetings.

During the past year our organization has enjoyed a number of instructive as well as interesting addresses by various noteworthy people. $\mathrm{Mr}$. H. L. Seamens, State Student Secretary, visited us shortly after school opened, giving us great encouragement for the coming year, as well as outlining the work for us, and delivering a fine address concerning his trip throughout Europe the past summer. We were also favored by fine messages from the local ministers, Rev. Harriman and Dr. White, of Cedarville, and Rev. Colman, of the Clifton Presbyterian Church. Each of these men delivered a scholarly and inspiring address. During the second semester, Mrs. J.P. White presented at four consecutive meetings of the Y. M. and Y. W., a series of talks, using as her general topic, "INDIA." We are certainly very grateful to Mrs. White for these precious talks, delivered in her very pleasing and attractive manner.

The regular meetings were led by various students, thus enabling each student to appear before a group of young men and direct their thoughts for that day. Although our Y. M. has not completed all the tasks which it set out to perform, yet we feel that it has passed another milestone with one of the most successful years in its history. The officers for the year 1922-1923 are: Donald Wickerham, President; Earle Collins, Vice-President; Gavin Reilly, Secretary; Arthur Findley, Treasurer.

M. E. C. 

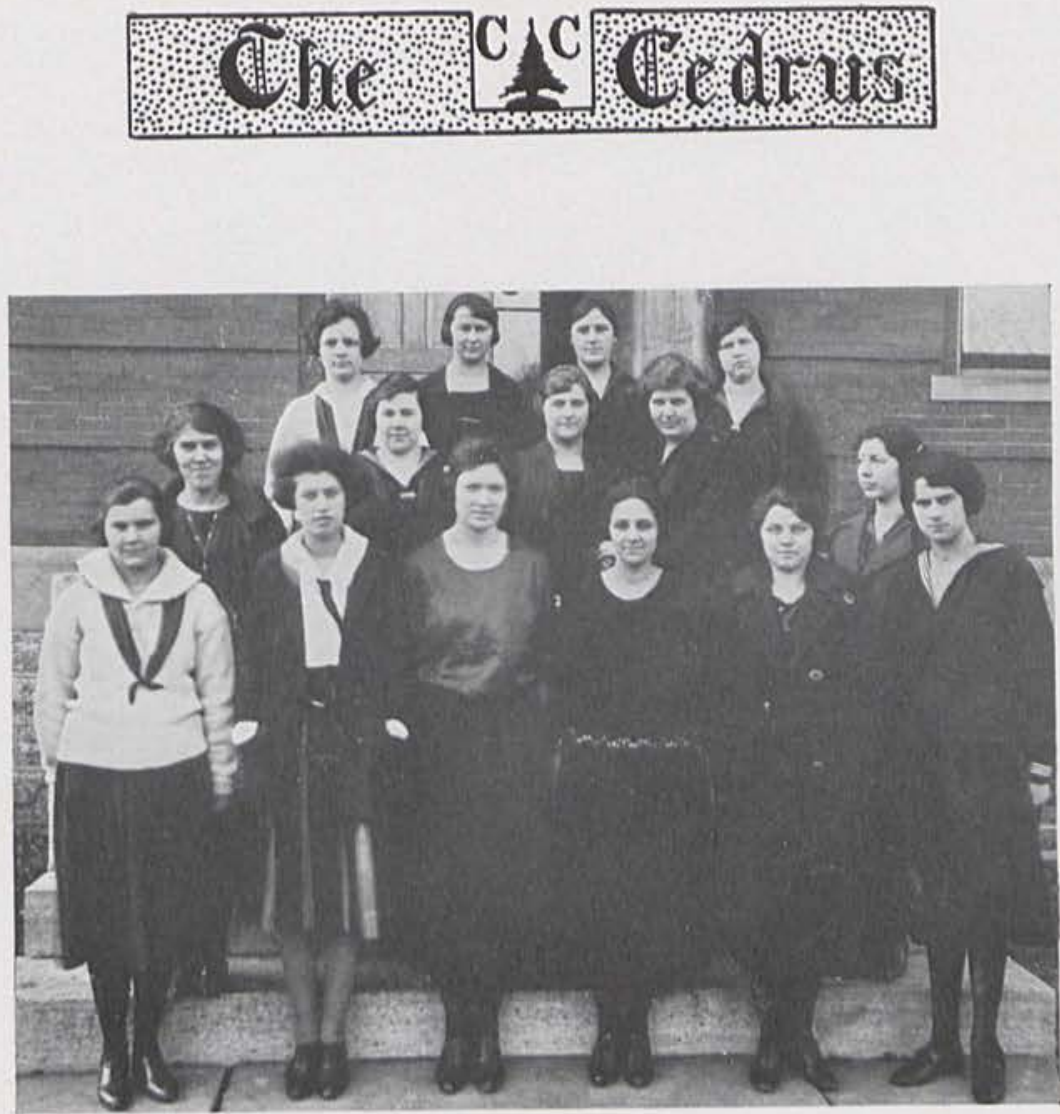

\section{LE CERCLE FRANCAIS}

The past year has seen the rise of a new society in Cedarville College, Le Cercle Francais. The club has as members, students studying second and third-year French, The society meets once a month at the home of the various members. At the first meeting, officers for the first semester were chosen as follows: Marjorie Wright, President; Lulu Murphy, Vice-President; Pauline Collins, Secretary and Treasurer.

The meetings of Le Cercle are carried on almost entirely in French. Programs consisting of plays, stories, studies of French life, and music are given. Games played in French are also enjoyed. The organization has a constitution stating its purpose. The emblem is the Fleur de Lis. The members of the society will soon be wearing very beautiful gold and silver pins as their emblem.

The purpose of the club is to increase the knowledge and use of the French language. It is thought that much may be gained through the informal conversation which takes place and that if the proper interest is shown it will be equal in value to the formal recitation in the class-room. Aside from the cultural aspect, each is brought into association with students who are interested in the same work and thereby they derive much pleasure. The club sincerely hopes that this organization may be a permanent one, and may continue to be as much a benefit and pleasure to the future students of Cedarville College as it is to the present members.

T. M. D. 

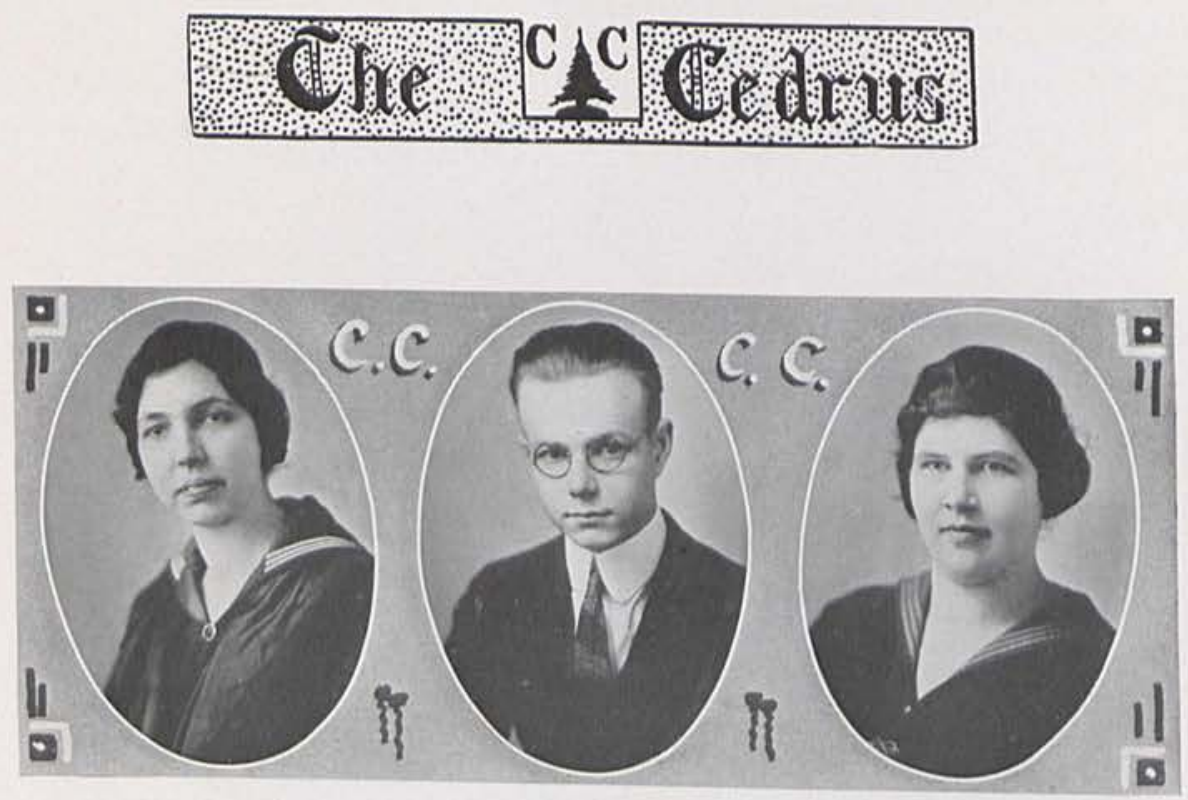

\section{THE CEDARVILLE COLLEGE CROWN CLUB}

The Crown Club was organized in 1920 and its membership is growing with each passing year. It is the honor society of Cedarville College. Members are elected to this organization by the faculty when they reach a certain standard in scholarship. To date, the club has a membership of six of which only three, Lucille Johnson, Thelma Deacon, and Marion Stormont are still in school. Other members are: Josephine Randall, Alice McKibben, and Helen Bradfute. There are several other students on the eligibility list so the number will be increased at the end of this year.

M. F. S.

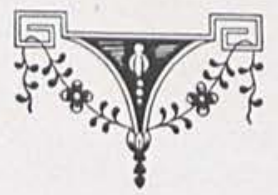



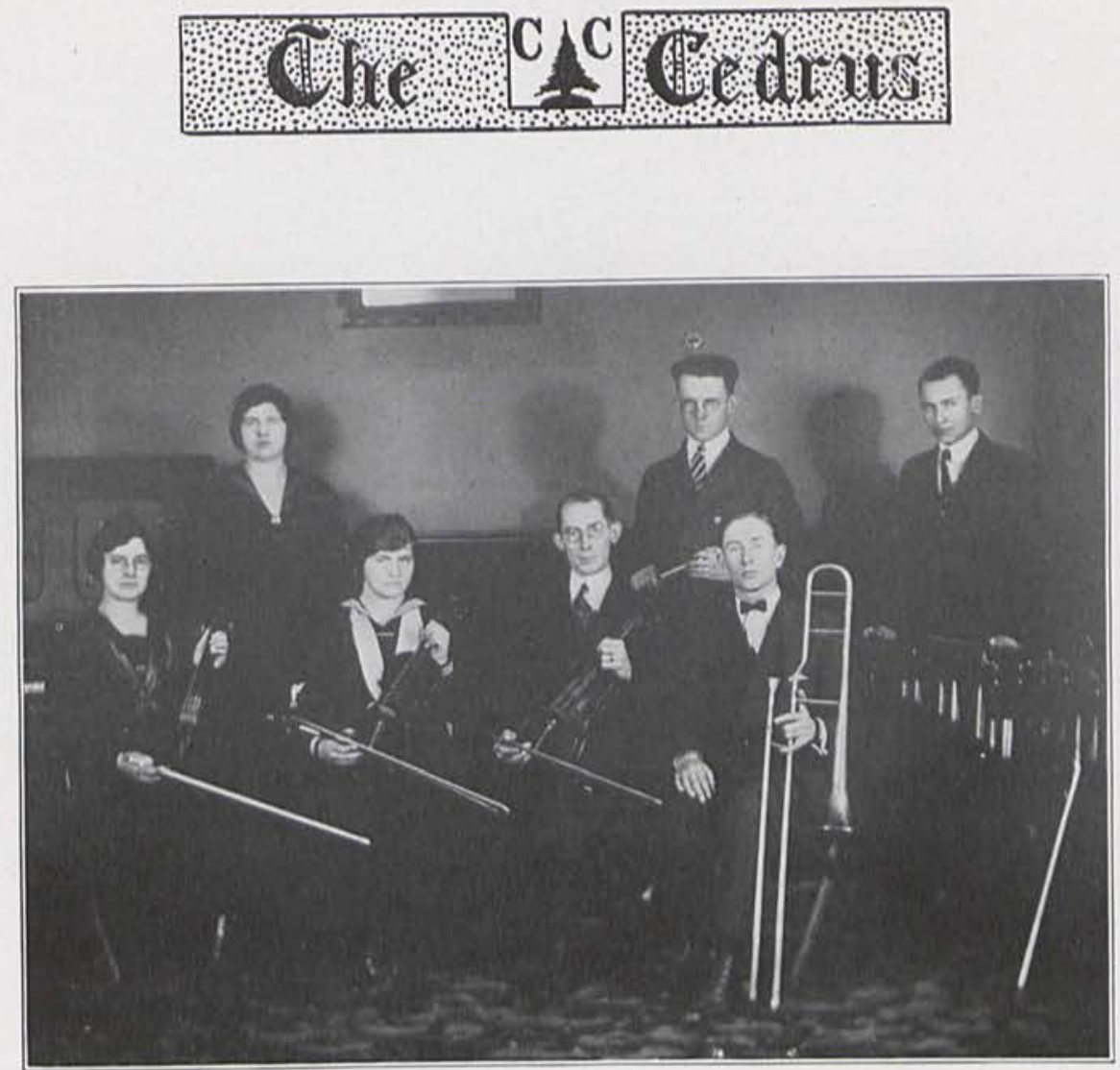

\section{C. ORCHESTRA}

When college opened in the fall of '22, the faculty, realizing that the aesthetic qualities of college life can be fostered by musical organizations better, perhaps, than in any other way, accordingly urged any persons who could play an instrument to organize an orchestra. The result was that the present orchestra, consisting of six pieces, was formed. Although all but two of the members were amateurs, they were soon able, by practicing weekly, to play creditably and made their first appearance November 22, 1922.

L. M. 


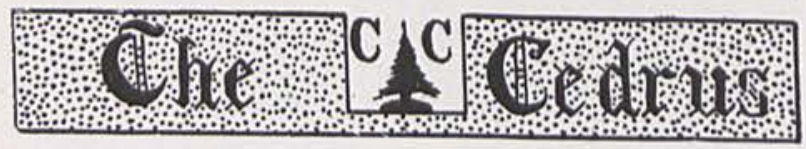

\section{THE RANGERS' CLUB}

The Rangers' Club is one of the newest and one of the strongest organizations in Cedarville College. It was established for the first time last year, and gave eighteen programs among the surrounding high schools. No medium has ever met with such success in local advertising as the Rangers' Club, and since every other business advertises its goods, we feel proud of the club in that it is placing before the public our high ideals, our needs, and our talent. Advertising is not the least end gained by this organization, for dormant talent has been developed and brought to the front.

There are about twenty members in the club. These form a varied program consisting of readings, speeches, orchestra numbers, vocal and instrumental music, and a short play. The plan of the club is to give programs on Fridays, one or two in the afternoon, and one in the evening. We feel that through these programs high school pupils receive more practical ideas of what is being done by the students of Cedarville College. Many pupils are unable to decide their course after completing high school. By presenting the different phases of our college life, we aid them in deciding to continue their education and to continue in Cedarville College. This not only helps the high school pupils but is profitable and enjoyable to the members of the club. Altogether we feel that the Rangers should be continued from year to year, endorsed by the loyal students of Cedarville College.

The club consists of the following:

\section{Readers- \\ Ruth McPherson \\ Hazel Williams \\ Marjorie McClellan \\ Mixed Quartette- \\ Dorothy Oglesbee \\ Lucille Johnson \\ LaClede Markle \\ Ernest Wright \\ Instrumental Soloists- \\ Forrest Nagley \\ Charles Townsley}

Pianist-

Lucille Johnson

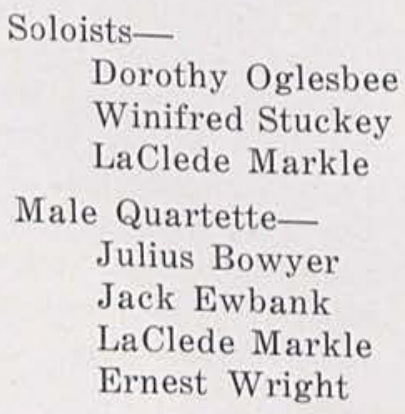

Dorothy Oglesbee

Winifred Stuckey

LaClede Markle
Male Quartette-
Julius Bowyer
Jack Ewbank
LaClede Markle
Ernest Wright

Faculty Members-

Professor B. E. Robison

Dr. W. R. McChesney 

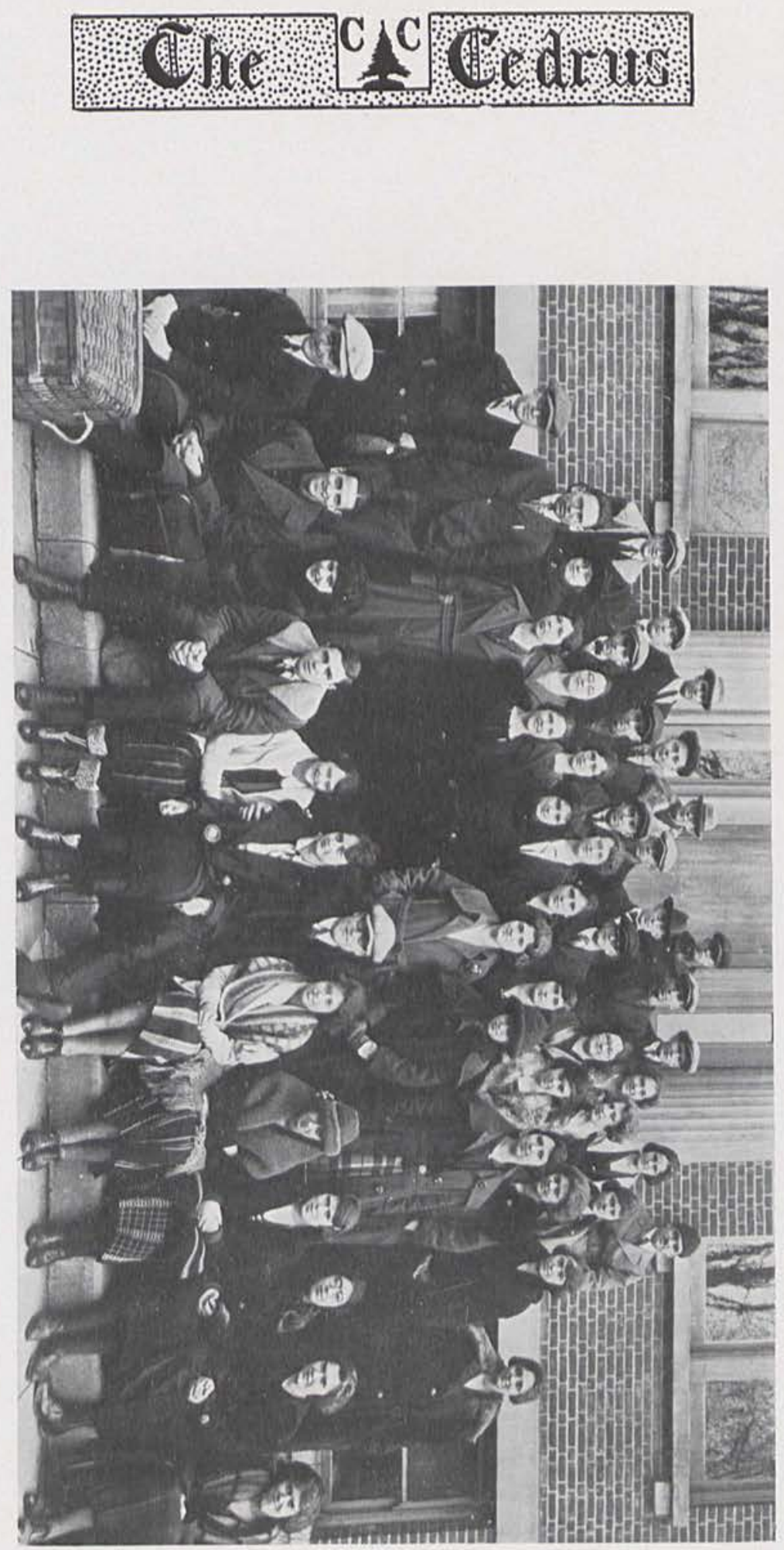


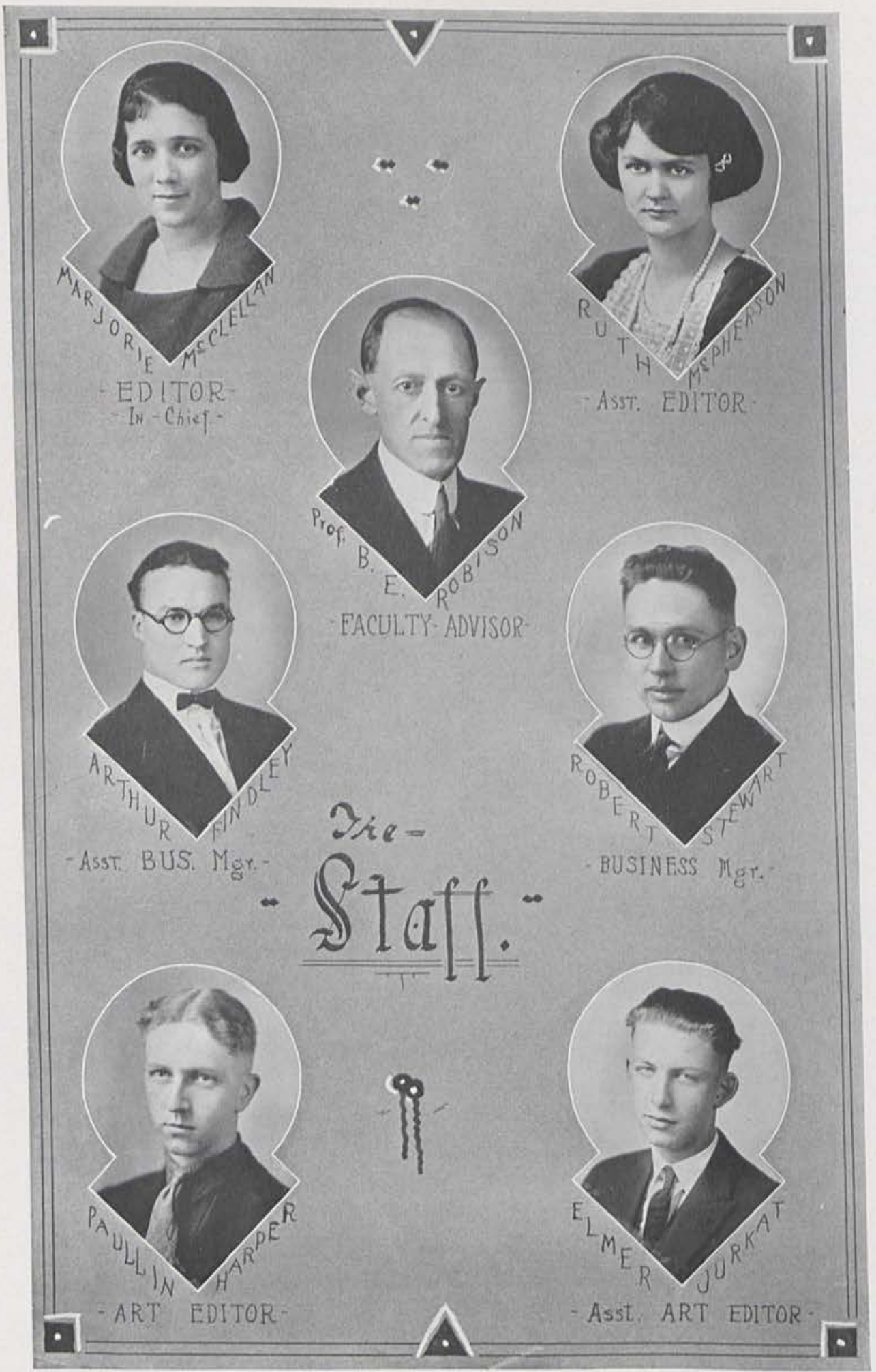




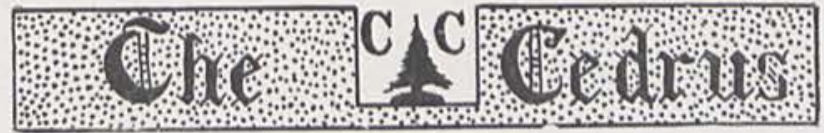

\section{THE STAFF}

The officers of the Cedrus Staff were all entirely new at the job. No one had ever been in such work before and as a result it was up to everyone of them to get busy and find out what to do and how to do it. Throughout the year we have had many difficulties and have done our best to meet them. At the end of the first term our artist, Mr. Harper, left school with his work half finished. The Staff at once elected a new member, Mr. Jurkat, to take his place. The Staff especially appreciate his work in taking up and finishing the artist's part of the book so well in such a short time.

We wish to thank all those who have helped us, giving us any material that might improve our book. We might pass on a little advice to next year's Staff, by telling them to start after material early and then keep after it hard until they get it. This year, however, we have found most students willing to help out and do the best they can for us.

The book was started in October when the new editor was elected. Since that time we have tried our best to make it a success that the students of this year may be reminded in years to come of the pleasant times they have spent here in college. We do sincerely hope that this Cedrus may bring to all of you many pleasant thoughts of fellowship with both friends and teachers of Cedarville College.-Editor. 


\title{
PRIZE STORY
}

\author{
BY IDELMA WICKERHAM
}

\section{THE CONDEMNED DORMITORY}

Mrs. Joseph Trumbull stood on the station platform, trembling and whitefaced, with her arms around the neck of her son and her fear-filled eyes looking pleadingly into his, "Now remember. Johnny, and do not do any of those dangerous things that I have warned ycu about. Above all, never sleep, or go into that terrible Condemned Dormitory. I just can't understand why men who have enough intelligence to manage a college, would allow the young men in the school to risk their lives in such a terribly foolish way."

Thus Mrs. Trumbull gave the final warning that was to be the saving power to protect her son, - the son that her watchful care and protection, according to her way of reasoring, had brought to his nineteenth birthday, physically strong and apparently the picture of health.

"Yes, mother, I would never do anything so foolish as to sleep in that dangerous place, but I do not think there will be much danger in just going inside for a little while, if the wind was not blowing. Do you?"

"Yes, Johnny, dear, I would never risk my life in there for a minute, for you never can tell what time the wind might start to blow and a storm might come up."

"Alright, mother. Good-bye,"

"Good-bye, Johnny," choked Mrs. Trumbull, and the train which he quickiy boarded, sped rapidly toward Thurston College.

John Trumbull was the only child of Mr, and Mrs. Joseph Trumbull, and being naturally very attractive, as well as being their own, he had become a victim of over afection and care. His mother, especially, lived in constant dread for fear that some accident or calamity would befall him. Although John was handsome and manly in his appearance, he had ignorantly allowed his well meaning parents to make of him, what the high school boys termed, a "sissy." He had been advised by his father, warned and rewarned by his mother, against the dangers they had heard were present at every college to threaten the life and limb of every young man who entered. But Thurston College possessed a danger all its own; for the old three-storied, brick building, that had once been the main college building, though now condemned, was being used as the men's dormitory, until a more modern, as well as a safer structure could be erected.

By most people the building was not thought to be dangerous, as the bulging at the ends had been duly checked by four strong rods that ran lengthwise and were securely fastened to four strong steel plates at either end. In fact the old structure had stood in the same condition for so many years that it had come to be thought of as an ordinary and necessary part of the institution. Few people feared it at all, and none of the students, at this particular period of the school's history, with the one exception of John Trumbull. John was fairly well liked and might have been very popular among the fellows but for this one short coming, fear of personal danger and the unwillingness ever to take a chance.

This characteristic is never advised by any group of young men and the youth of Thurston College, while they were far from being a "bunch of rough-necks" were no exception to the rule. They therefore determined either to cure John Trumbull of putting such a high value on his personal safety, or at least to have some fun at

$$
\text { (Continued on page 92) }
$$



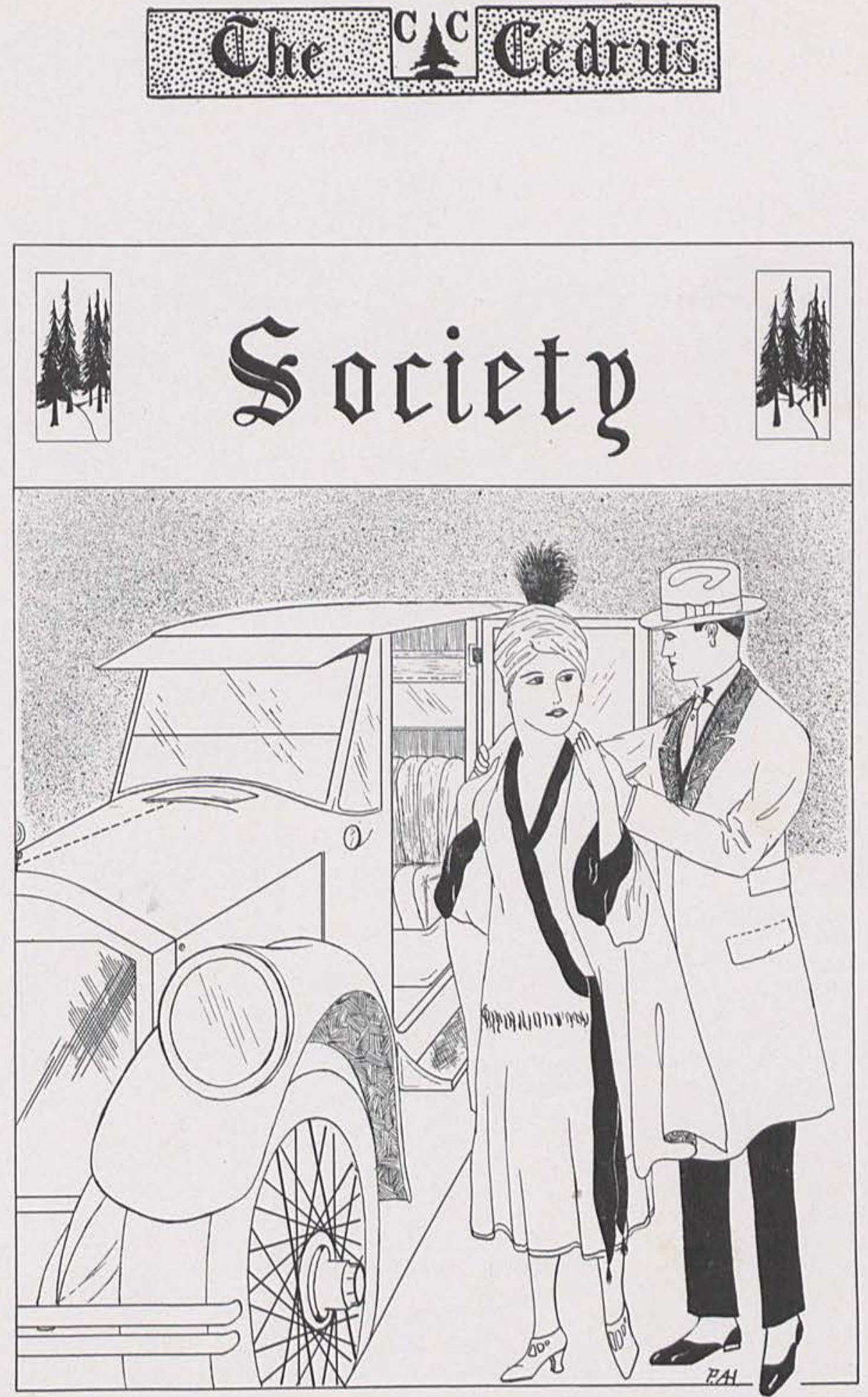


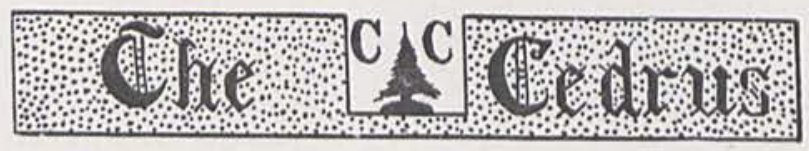

\section{THE HALLOWE'EN PARTY}

The Hallowe'en Party this year was held in the gymnasium on October 30. To say that this party was a "howling" success would only be putting it mildly. The arrangements were in the hands of the Y. W. C. A. and were carried out well. The boys received mysterious invitations telling them to meet at "Doc's" at $7: 30$. The boys were there, and it seemed from the costumes that there were girls, too, but evidently looks were deceptive in that case. Soon there came a fancily decorated wagon bearing several ghost-like forms. We boys were invited to pile in and did so with speed. That is where the "howling" comes in. After parading up and down the streets for a time we were hauled to the gym. Don Wickerham almost killed himself in his hurry to get in by falling off the wagon. The gym was a wonderful sight, one could hardly realize that such a transformation could take place. After all were in, the parade began, the parade by the way, being a cross between an aesthetic dance and a route march. At the end of the march a prize was awarded for the best costume. "Billy" Arnott was the prize winner; Lois Ater and Martha Johnson received honorable mention. After the presentation, games were played and fortunes were told. The fortune tellers were Miss Porter and Miss Murdock. Miss Porter told some wonderful fortunes with which everyone seemed to be delighted.

Refreshments were then served, or rather, we should say a feast was served. The "eats" were wonderful, the girls evidently having heard of the saying, "The way to a man's heart is through his stomach." Ham and cheese sandwiches, pumpkin pie, doughnuts and cider, with a candy apple for desert were spread around and all, except the fortune tellers, got busy. At a late hour the party ended and the students wended their weary way homeward, and no lessons in the morning.

F. W.

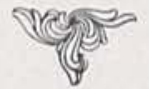

\section{CHURCH RECEPTIONS}

One event always looked forward to by the students of the College is the first Friday after school opens, when they are entertained by the Christian Endeavor Society of the Reformed Presbyterian Church. This year it seemed that they enjoyed this event more than ever. On arriving, guests were divided into a number of groups for different contests. Different members from each group were sent out for each contest; cheer leaders were chosen. Altogether the guests seemed to have a great deal of fun. After each contest was over a prize was given to the winning group. Refreshments were served and the guests left for home after a wholly enjoyable evening.

The College was again entertained toward the middle of the year by the United Presbyterian Young People's Society. This social was planned in order to give a good laugh to everyone. It was what is called a "backward social." Guests were received at the back door of the church and made to enter backwards. Ten beans were given to each person on entering, and anyone who could make another say, "Yes" or "No," might demand a bean from him. A box of candy was awarded the one who had the most beans. A number of games and contests were enjoyed during the evening. The refreshments were served, still carrying out the idea of the "backward party," finger bowls being passed first, and napkins last. 

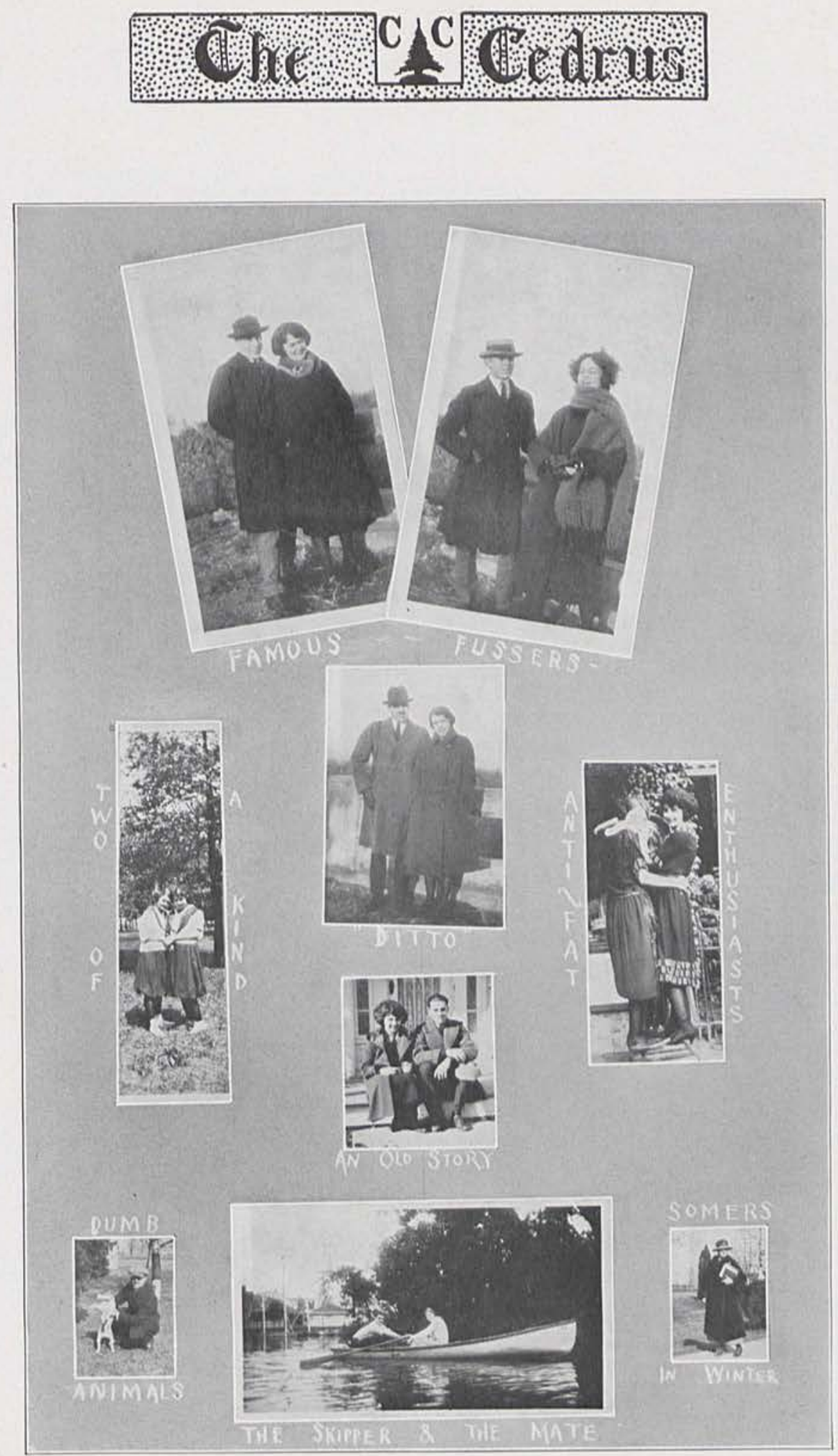


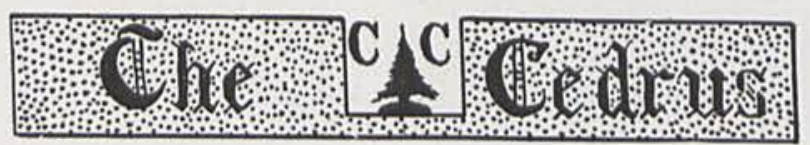

\section{SOCIETY CALENDAR}

September 12. That was the night new scholars and old became "closely" acquainted on the truck ride to Bryan Farm.

September 13. College opened with the opening address given by Rev. Tilford, of Xenia. Faculty entertained at the Gym.

September 15. Students and faculty entertained at the R. P. Church.

September 20. Rah! Freshmen spread-ask Lois Hutchison or Marie Meahl.

September 27. Another (attempted) Freshmen spread. Barbed wire fences are dangerous things to try to vamp.

September 28. Some of the Senior girls were voted good cooks after the Y. W. feed at Doc's.

October 2. Wiener roast at Bryan Farm-some people "swear off" on trucks,

October 11 . Wonder why such a small Gym class?

October 17. Who broke the water pitcher at Eloise's surprise party?

October 26. The night the Freshman girls were entertained by the C. C. boys at the show- 1 guess we had a good time at Winnie's and I guess we woke the town afterwards.

October 30. Girls! Remember how we worked on Hallowe'en and what an exciting evening we had???

November 1. Can it be that Larrie and Walk had their room stacked?

November 10. Are we goin' to beat Antioch?-Ya-boo. You bet we did.

November 11. Johnnie and Markle opened a boxing course.

November 24. Cedarville went to Dayton to hear Billy Sunday and Larrie fell through the new Science Hall.

November 25. Lois Cummings entertained with a dinner party at her home. Swing backward, oh time in your flight- such eats.

November 27. French Club organized at Miss Brand's. December 6. Did we hear Betty and Ruth had their rooms stacked? You are wrong
-it was a cave-in.

December 7. Lillian yielded to temptation-thou shalt not eat between meals.

December 9. Ruth DeWitt entertained at Galloway's cabin. Ask Marj. W.

December 16. Surprise party as Jack's.

December 17. Night of the peanut episode.

December 19. Riff-Raff-Ruff, we're gettin' tough. But not tough enough for the Boring-Yanks though.

December 21. Sent home to watch for Santa Claus.

January 2. Party at Flossie Smith's.

January 5. The night we won from the Boring Yanks.

January 10. Aren't we proud of Yank in his "Cop" uniform though?

January 20. Markle entertains for his Columbus friend. Where???

January 25. That was the night of the Antioch game. 


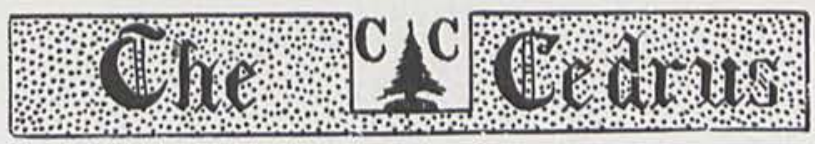

February 1. They say they don't allow coaching from the side lines in Cincinnati.

February 6. Mr. Pearson makes his entrance into "club" society.

February 8. McKune got "reckless" coming home from a funeral.

February 9. Prayer day. Rev. Baumann is speaker. Our mascot "Spike" died and we all mourned.

February 13. Marjorie Mac entertained with a 7 o'clock dinner and Dorothy Tarr entertained with a Freshman Valentine party.

February 17. A number of college students enjoyed a rook party at Kathleen Blair's.

February 20. Lecture course-Dick and Marjorie, Ray and Flossie, the eternal quadrilateral had dates.

February 22. Number of C. C. students enjoyed Antioch. Ohio Northern game at Antioch.

February 23. Ohio Northern plays Cedarville.

March 2. Basket-ball girls left for Cincinnati.

March 8. No more dates for awhile, girls. Minstrel practice began.

March 10. We saw Cedarville High bring back the tournament cup.

March 12. We saw Billy disappear according to the interpretation given it by the Junior Class.

March 13, 14, 15. Inter-class games-Miss Somers starred for the Juniors.

March 17. We didn't know whether part of the people were Irish or just Freshmen.

March 27. We hope Larry found what he was looking for in Chapel.

March 28. And a howling success was the minstrel.

March 29. Spring vacation is here, also the foot-ball and basket-ball letters.

\section{HARD LUCK}

(As experienced by Findley and Ray, November 30th, 1922.)

1. Went hunting (for rabbits), didn't see a darn rabbit.

2. Found out the windshield was broken when we started for Cedarville.

3. Called first girl—no response.

4. Called second girl-mother said she was out of town.

5. Called third girl-no response.

6. Called third girl again - just as talkative as ever.

7. Went to Harriman's. Mr. Harriman invited Ray to come back again; Ray didn't hear so Findley accepted. Mr. Harriman told him he didn't need an invitation as he came in at all hours.

8. Went to show. Late, saw just enough to get interested. Everybody but Findley and Ray left and, naturally, looked. Operators said there would be no second show so we had to leave.

9. Saw aforementioned second girl going out of show-not by herself either.

10. Went to Doc's and had the only "Lucky Strike" of the evening.

11. Saw aforementioned third girl-wouldn't speak to us.

12. Went to Collins' to play a few cards-Findley and Ray alternated playingwhichever side one of them happened to be on got "set."

13. Number thirteen!-Lost the blummin' hard luck publication between sunrise and sunset. 

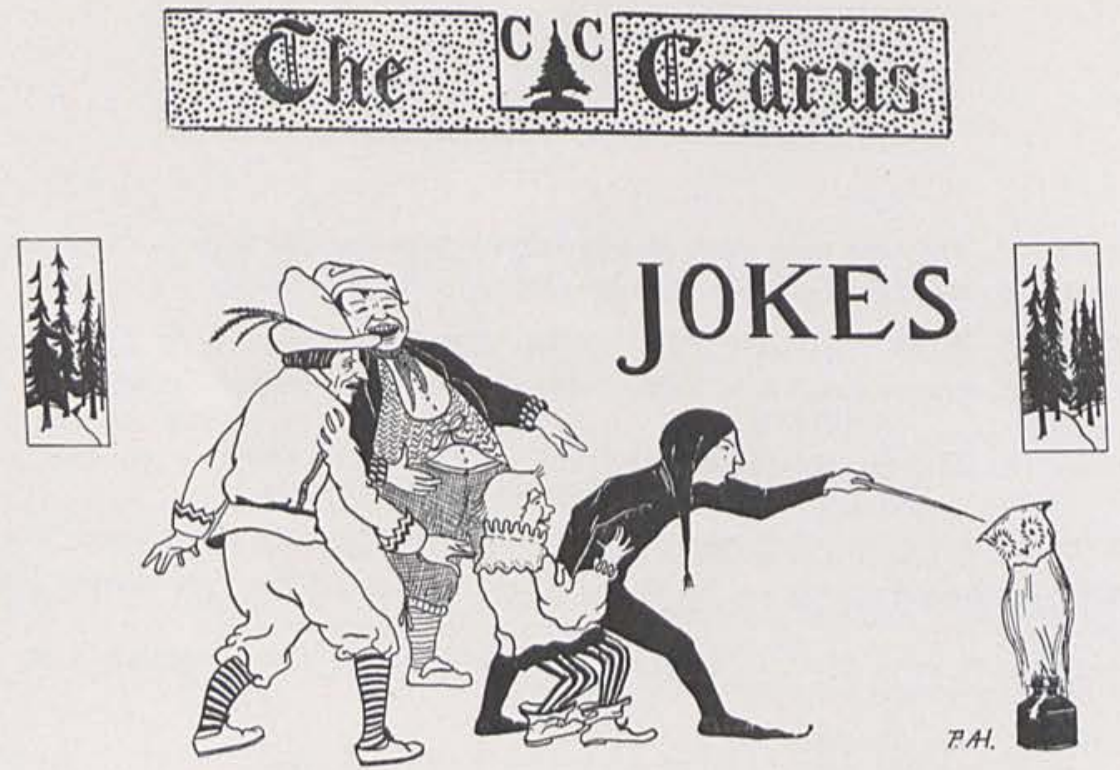

Freshie: "My mind is my memorandum."

Sophie: "Oh, I see. A sort of blank-book."

Prof. Frazer: "Hydrogen is a reducing agent."

Dot Oglesbee: "Oh, please give me some."

Bill Snell: "Tell me about Ray's travels."

Elmer Jurkat: "While in Italy, he spent much of his time visiting Florence."

\section{FARCES WE RECOMMEND}

I'm Engaged

"Yank Stevens"

Men Not Wanted

Lois Hutchinson

Minnie at the Movies Dorothy Oglesbee

Who's the Boss Marj. Mc.

She Says She Studies Freda Crowell

Wee Willie Winkie Fred Wills

This is So Sudden Lois Ater

I'm a Nut yumn Peters

Not a Man in the House Oglesbee Dorm

Professor Pepp.

Marion Stormont

Wanted: A License to Wed .Jack Ewbank

The Dearest Thing in Boots

Almost an Actor Lillian Hopper

An Easy Mark Don Wickerham

Much Ado About Betty

$\mathrm{Oh}$, You Teacher Earle Collins

An Awkward Squad

Do Birds Tell Everything We Do?

Howard Arthur

A Pair of Burglars Avanelle Brigner

All on Account of Polly

Just Arrived from Bashful Town Girls' Gym Class ..Paul and Hazel Pete and Larrie Teacher, Can I Go Home?

Charles Townsley ..Funk and Hunt ..Gould Peters 


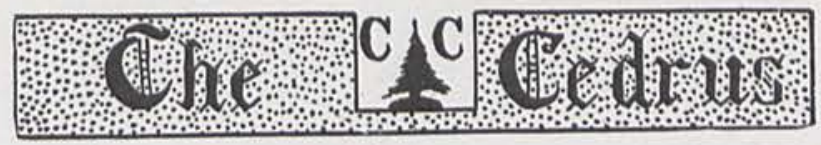

At the Football Game

Lucinda Caskey: "Do you suppose they ever get those poor boys' faces clean?"

Lucille Johnson: "Sure, what's the scrub team for?"

Prof. Frazer: "Give an example of food containing mineral matter."

"Pete": "Rock Candy."

Jack Ewbank: "I wish to ask a question concerning a tragedy."

Prof. Robison: "Yes?"

Jack: "What's my Bible grade?"

Mrs, Kyle: "I found seventy-five cents in your bed this morning."

Henry: "Ah, my sleeping quarters, no doubt."

Herb. Main: "The dentist tells me I have a large cavity that needs filling."

Dick Elder: "Did he recommend any special course of study?"

Alberta Hemphill: "Harper Bickett says he means to be an aviator."

Dorothy White: "Well, he always was flighty."

Miss Brand: "What does Q. E. D. stand for?"

Lillian Hopper: "Quit and eat dinner."

Coach Warner: "Instead of burning the midnight oil, some of our boys are burning the midnight gasoline."

Mother Arthur: "You were out after ten last night, Howard."

Howard Arthur: "No indeed, I was only after one."

Dick Cooper: "I'm doing my best to get ahead."

Miss Somers: "Goodness knows you need one."

Miss Porter: "What makes the Tower of Pisa lean?"

Martha Beam: "If I knew I'd try it."

Mary Flannagan: "Don't you get hungry in that fourth hour history class?"

Marj. Wright: "No, I'm fed up on dates and current events."

Miss Brand: "Who wrote the story you are reading?"

Forrest Nagley: "A man named 'FINIS.' I've read about a dozen of his works."

"How is your cold, Eloise?"

Eloise: "Very obstinate."

"And how is your brother?"

Eloise: "About the same."

Marie Meahl: "They say Orpheus of old could make a stone wall move with his music."

Forrest Nagley: "That's nothing, why I made two families next door to us move."

Charles Brown: "Well, I suppose you are ready for the sheep-skin?"

Ernie Wright: "No, it seems as if I am going to be a goat." 


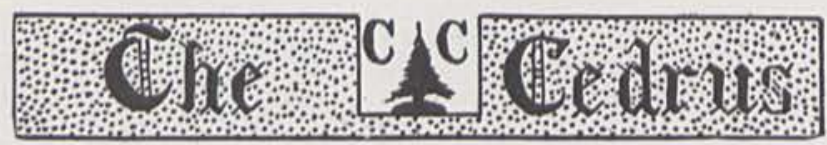

\section{Favorite Songs of Favorite People}

Irene

LaClede Markle

Bee's Knees Johnnie Davis

My Home Town Larrie Currie

Ain't Nature Grand

Honeymoon Waltz

Do-Do-Do It Again allace Findley wight McKune

The Vamp Betty Gifford

Margie Bobbie Kalp

Poor Little Me Dick Dovel

Marion Marston Hunt

Angel Child Lucille Johnson

Johnnie's in Town Frank Gerren

I Was Born in Michis Bee Walton

Grieving for You Billy Arnott

Carolina in the Mornin

Where is My Wandering Boy Tonight?

Cutie

Canadian Capers

You'd Be Surprised hy Oglesbee

Three O'clock in the

All the Quakers are Shoulder Shakers Eloise Davis Miss Brand

Lois Cummings Christine Kyle Walker Taylor

Miss Brand: "You are too literal, you don't read between the lines enough." Thelma Deacon: "I can't very well, it is half erased,"

Rock-a-bye, Seniors, on the tree top,

As long as you study, the cradle will rock.

But when you stop working the cradle will fall, And down will come Seniors, diplomas, and all.

"Dr." Richards: "Don't you know how to make a fire yet, Howard?"

Howard Arthur: "Nope."

Betty Gifford: "Well, believe me, you'd better learn mighty quick, then."

GOOD FRIEND, FOR HEAVEN'S SAKE FORBEAR

TO SCORN THE CEDRUS ATTEMPTED HERE;

BLEST BE THE STUDENT THAT DOESN'T MOCK, AND CURSED BE HE THAT STARTS TO KNOCK. 


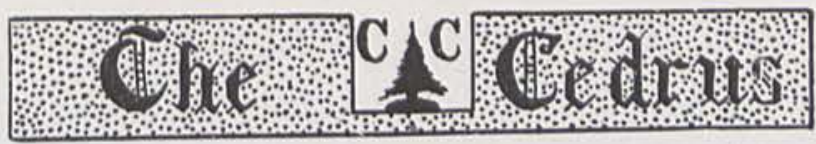

\section{Advice to The Querulous}

This department has just recently been organized by the Cedrus Staff. We have received many more questions than can be published, but if the questioners will come to us privately we will be glad to answer them. We sincerely hope that the answers given here will be satisfactory.

Thelma D. That is altogether too much time to spend on your studies. I think that three or four hours an evening is all that is required of you.

Lillian H. An arts' course is good. We advise liberal arts, it sounds as if you would have a better chance.

Dick D. It is bad taste to linger too long at the door while escorting. The young lady's mother was perfectly right in making you go to church on Sunday night if you have a date.

Don W. Judging from the photographs sent in with your query, I judge that you should make a good aesthetic dancer. And certainly, it is popular.

L. Caskey. Your ideas are too flighty. Your amateur success on the stage does not warrant your leaving home. Furthermore, you would have no possible chance on Broadway, for there are many others like you.

Julius B. Yes, the color scheme of yellow shirt and green tie is especially good this year for use on the Rangers' Club.

Johnny D. The best that we can advise for making an impression of great size is wide-checked trousers, coat and vest. It is a sign of weakness to part the hair in the middle.

I have a boy friend who is very particular about my running with others. Would to go riding with another man about my age if $\mathrm{I}$ happen to be in Dayton and my friend is in Xenia, especially if the man I go riding with is a real-estate agent?-L, C.

To L. C. Considering that you are looking for a future home, your young friend would surely not care for you riding with a real-estate agent.

would like to find out how to get a husband who would be willing to own a farm and let me run it? I am very much interested in agriculture and would like to have a farm to start out on.-M, E, D.

Anyone who can qualify will please let us know and we will give you the questioner's address.

I would like to know how to stick to one girl. Could you give me any advice as to when one really is in love?-G. L. M.

To G. L. M. We would advise you to go ask either Gavin Reilly or Christine.

Do you know of anyone who would like to take a course in flirting? I can give them such a course any Friday if the parties will just go out with me on Rangers trips.-D. O.

To Dot. O. Mr. Pierson informs us that he will be glad to take the first lesson. 


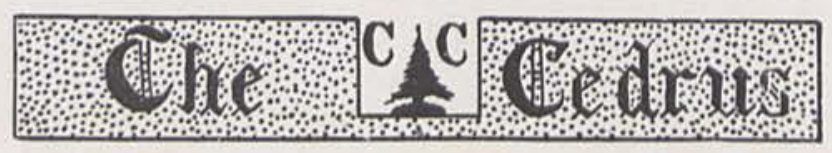

BOOK VI - ADVERTISEMENTS

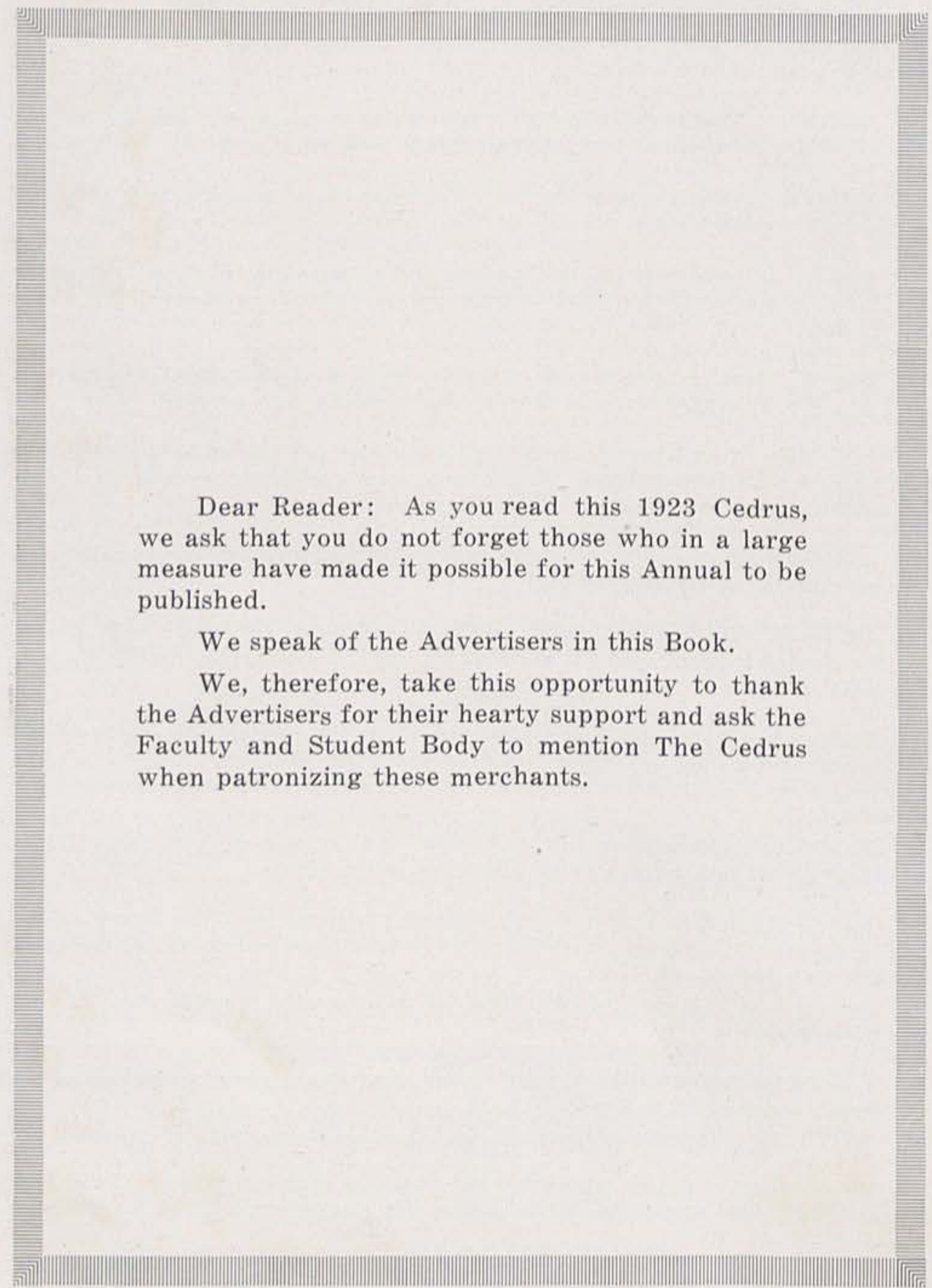




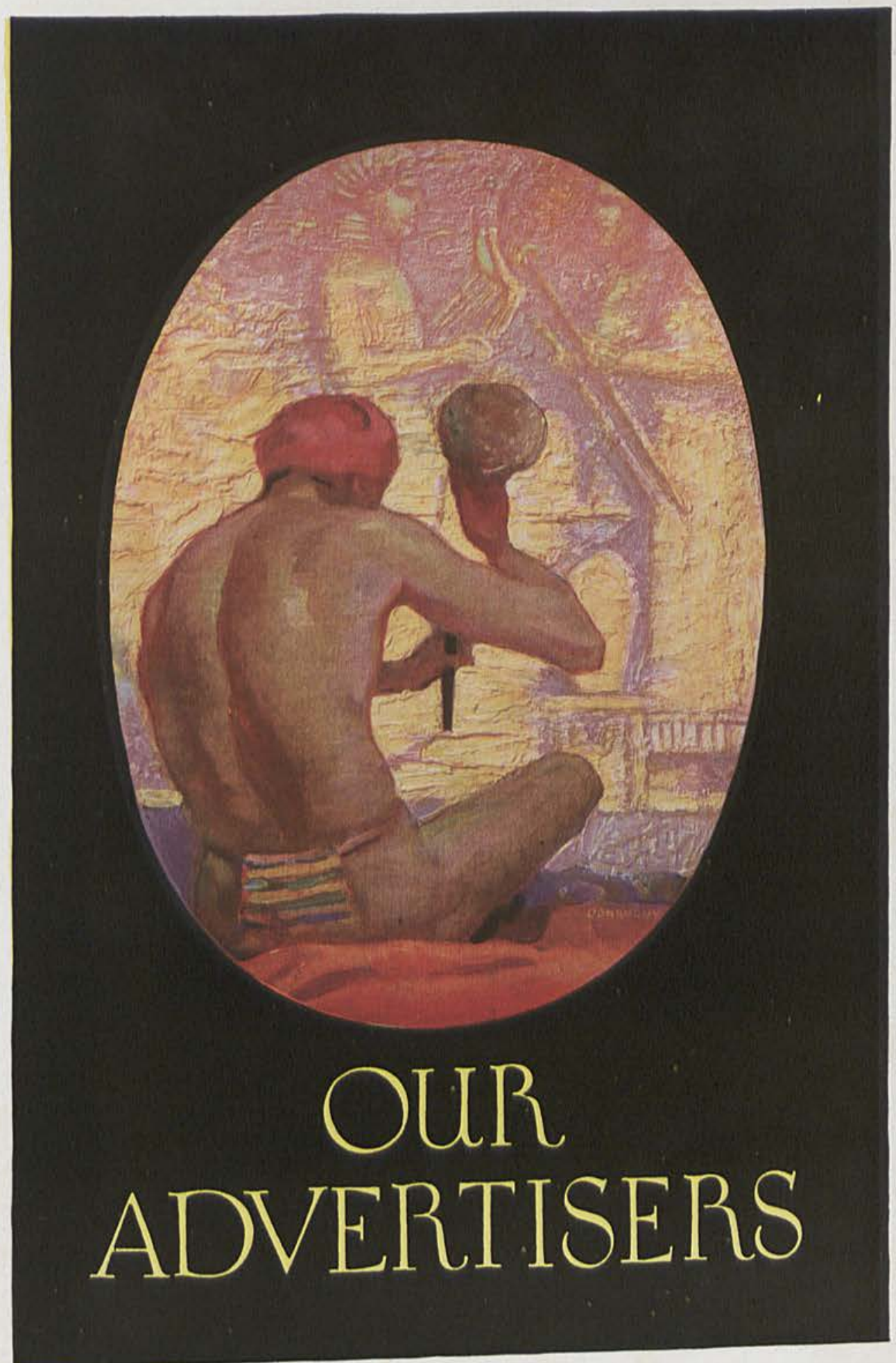




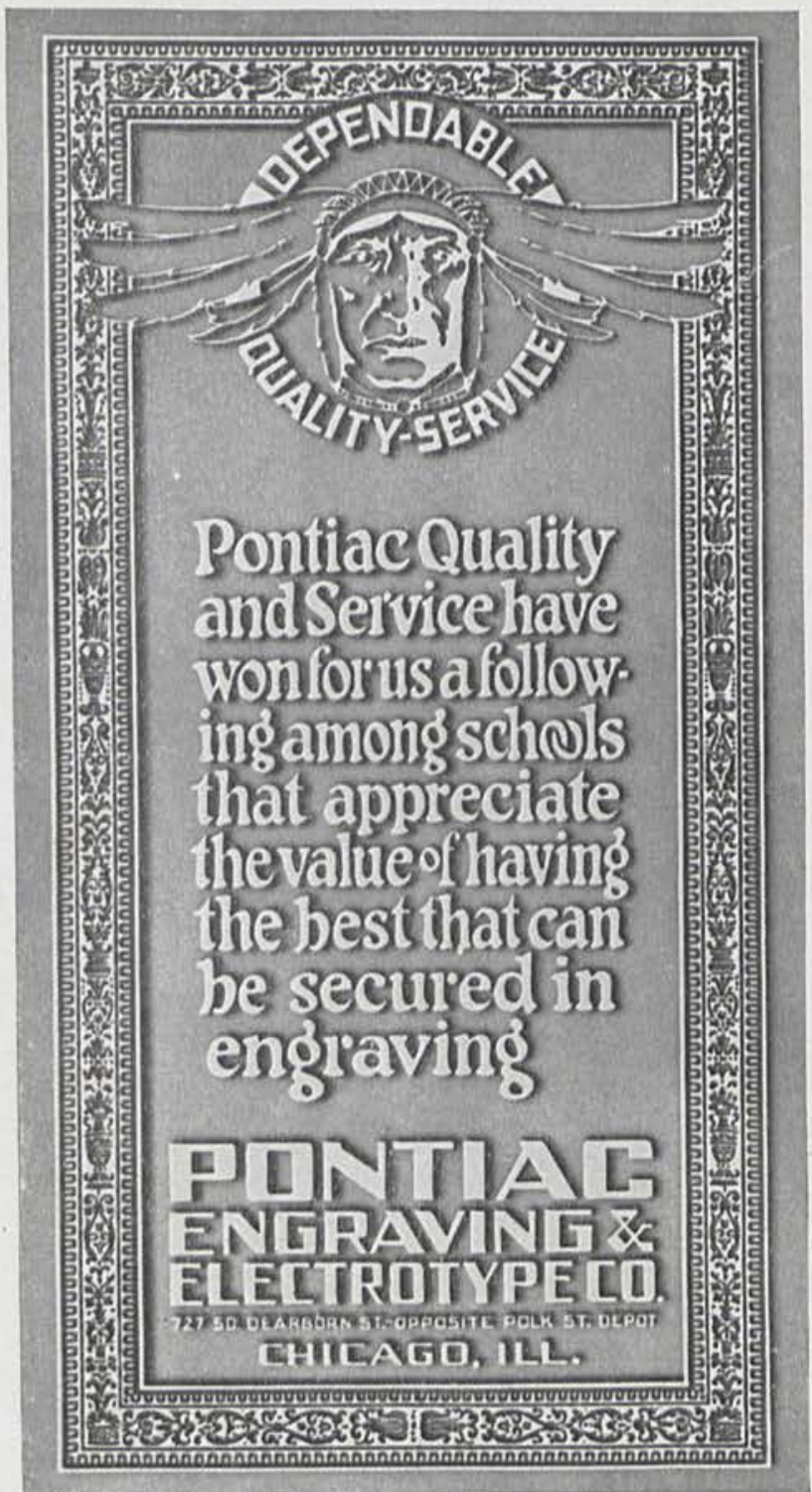




\section{Cedarville College}

\section{Is Forging to the Front}

\section{Get A College Training}

The times demand it.

The results justify it.

\section{Come to Cedarville College}

The location is healthful and beautiful.

The opportunities are fine and inspiring.

The courses are complete and modern.

The influences are safe and helpful.

The expenses are lower than at many other places.

The students are possessed of high ideals and practice them.

The faculty is experienced and thoroughly trained.

Foot Ball, Basket Ball, Base Ball and Tennis

Physical-Education and Gymnastics

The College is recognized by the Department of Public Education of the State of Ohio, and by the leading universities.

In Cedarville College you can get preparation for any pursuit in life.

A large Freshman class is to enroll in September. The prospects for a record-breaking attendance are splendid. Largest attendance in history of the College last year.

Thirtieth Year Opens September 11, 1923

For catalog and further particulars, address

\section{W. R. McCHESNEY, Ph. D., D. D., President \\ Cedarville, Ohio}



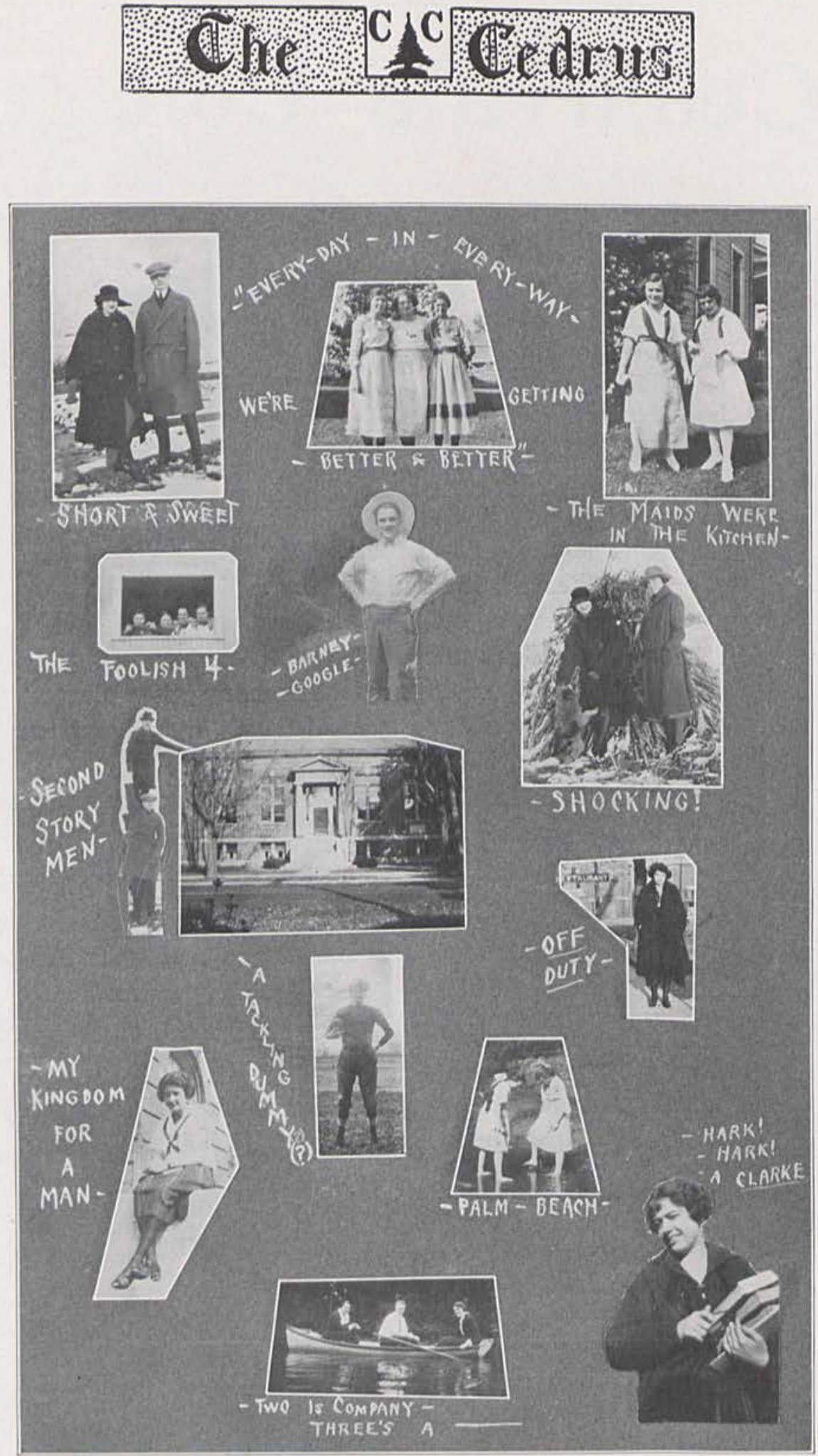


\section{Wolff Brothers}

\section{Tailors}

Cappel Building, Ludlow Street, near Fifth Street Home Phone 6894

$$
\text { Dayton, Ohio }
$$

R E M E M B R A N C E

"There is a voice from the tomb sweeter than song; there is a remembrance of the dead to which we turn even from the charms of the living."-IRving.

An artistic Marker or Memorial has a far greater value than that represented in dollars, for it is placed in remembrance

THE GEORGE DODDS \& SONS GRANITE CO.

"Art in Memorials"

113-129 W. Main Street

Xenia, Ohio

IS IT SOMETHING TO WEAR?

If so, we have it in Good Quality at Medium Prices

MEN'S AND BOYS' HIGH GRADE CLOTHING, HATS FURNISHING GOODS AND SHOES

For the Whole Family

\section{Home Clothing Co.}

G. H. HARTMAN, Proprietor 


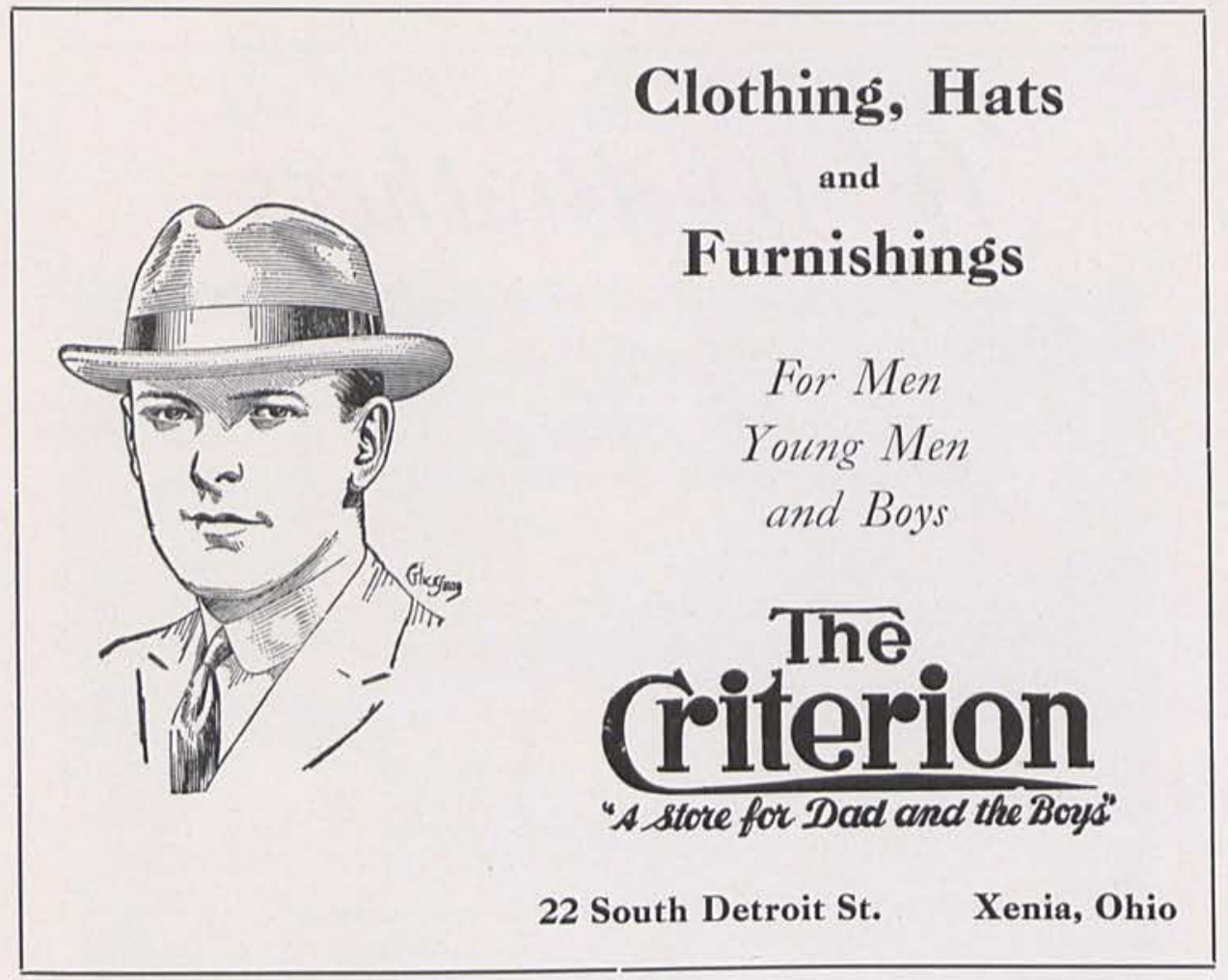

Wickerham in English class: "I am the only boy in a class of thirteen girls. Now I don't call that unlucky."

Girls after gym class: "What sort of costumes will we wear for this dance?"

Coach: "Oh, that's merely a small matter."

Lena Hastings: "Yes, merely a small article."

\begin{tabular}{|c|c|}
\hline Boring's Book Store & J.Thorb Charters \\
STATIONERY & T H E \\
SPORTING Goods & J E W E L E R \\
OFFICE SUPPLIES & X E N I A \\
O H I O \\
6. Detroit Street, Xenia, Ohio
\end{tabular}




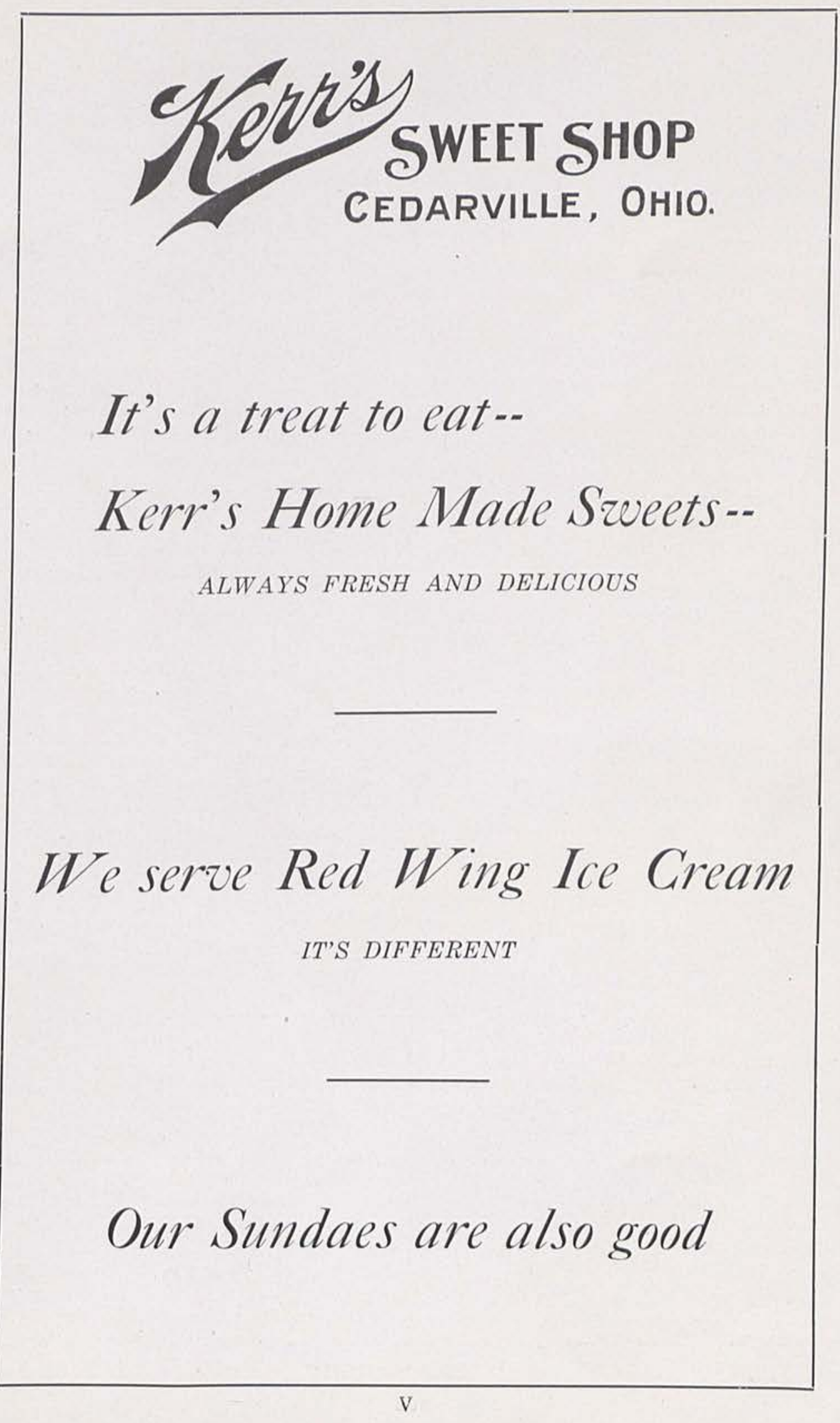




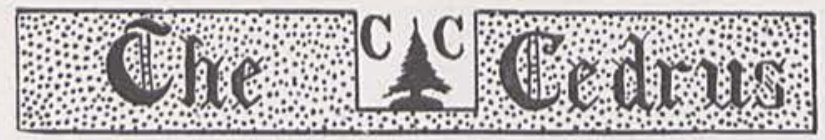

(Continued from page 76 )

The Condemned Dormitory

his expense. In fact, they would endeavor to show him where he stood in regard to his over-estimation of himself, a thing of which he evidently knew little.

John had, as he thought, shown his superior wisdom as well as his better judgment over the other fellows in ignoring the unsafe dormitory as a place to trust his mother's only son and his promising career. So he had selected a room in a good substantial, private house which was, however, some distance from the college. But several times he had been persuaded to risk the dangers, and had entered within the walls and beneath the roof of a condemned building. Although at first he showed much uneasiness and no desire to prolong his stay, he had become rather used to the uneventful visits and had begun to feel as if the old building looked rather amused at him out of its window eyes, as he, on leaving, stepped hastily out of its door and looked back over his shoulder as he approached a position where, should the walls fall, they would not reach him.

But as yet no one had ever succeeded in persuading John to spend a whole night in the building - to trust his closed eyes and unconscious mind to repose within its dangerous walls. He had so far refused all invitations. At first he professed open fear; then, as he gradually grew accustomed to the place, and learned to care more for the good opinion of the fellows, he proceeded to excuse his refusals by telling them that he would accept their invitations to stay, had he not made promises to his mother that he would not; though inwardly he was rather glad that the promise had been made. Several times he had stated that he would not be afraid to stay in the building over night, if he was sure the wind would not blow.

At last, being over persuaded, John had promised the fellows that, if it remained quiet during the evening, he would stop on his way home from society and spend the night with his friend, Jack Crawford. John had felt an unusual thrill of pride as he had made the promise, but as he now walked alone past the old building on his way home from dinner, it seemed to renew all of its former terrors and to add a few that were entirely new. The ends seemed to have recently bulged farther out; the front wall seemed not to be standing plumb, and the rusty tin roof appeared to have recently sagged. Secretly he wished that the wind would start to blow.

The October night was crisp and clear; not a leaf stirred on the rows of trees that lined either side of the broad walk in front of Condemned Dormitory, as John Trumbull accompanied by a number of his companions made his way toward the old structure. The quietness and the bracing atmosphere, together with the companionship of friends, gave John new courage and, at a little jibe from one of the boys, he told them he had no fear whatsoever of sleeping in the old building.

Games and prearranged amusements lasted until so late that John jokingly remarked that he did not believe he would have a chance to sleep in the Condemned Dormitory after all. But soon, when the other boys considered that John was sufficiently exhausted to go to sleep quickly, they all made ready for bed.

Jack had, without previous knowledge to John, changed his sleeping apartment to the third floor of the building. On this John made no comment and to himself reasoned that he would, after all, just as soon fall on top of the building as to have it fall on top of him. Of course he would not have the same chance to get out should it start to fall. Before he entrusted himself to the bed he tried vainly to listen at the window for the sound of wind, without attracting the attention of his chum.

The careless way in which Jack plunged into the bed, together with his own physical exhaustion, soon caused John to sleep so soundly that he did not hear the deft moccasined feet as they noiselessly bore a score of owners to their previously arranged positions of vantage. Nor did he notice the shaking forms of two human (Continued on page 105) 
The New Spring Shipments of Hart Schaffner \& Marx and Fashion Park Suits are in, also The New Dobbs Hats, which are so popular with College men all over the country.

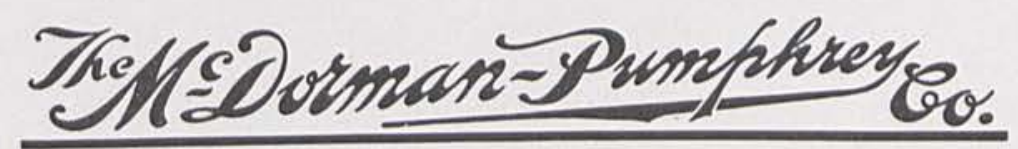

XENIA—Stores-JAMESTOWN

A. Winter, Proprietor

A. E. HUEY

Repair Dept.

\section{SER VICE}

THAT'S US ON

Hardware, Paints, Plumbing, Electrical Supplies, Tires and Accessories, Lubricating Oils, Metal Cribs, Roofing

Spouting, Pump Repairs

There's a Difference, You Save It

\section{Service Hardware \& Supply Co.}

Phone 148

Cedarville, Ohio

Miss Brand: "Complete the verb, 'bring'.,"

Clara Edler: "Bring, brungeh-fetch!"

"Mac, what course are you taking to graduate?"

McKune: "It seems to be the course of time."

At a basket ball game Mary Agnes Harper arrived at the beginning of the second half.

Mary Agie: "What's the score?"

"Nothing to nothing."

Mary Agie: "Oh! goody, then I haven't missed anything."

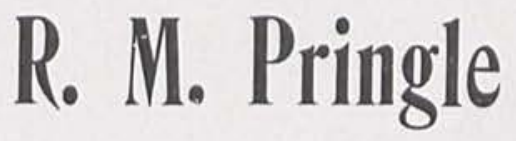

MEAT MARKET

Dealer in

ALL KINDS OF LIVE STOCK

Phone 68

Cedarville, Ohio 


\section{Robert Bird \& Sons’ Co.}

\section{The Store That the Students Make Their Headquarters}

WE TRY TO PLEASE THEM

Get your education at Cedarville College, and make your college life pleasant by forming that good habit of "Buying at Bird's."

We have a department for the boys as well as one for the girls.

We take this opportunity to thank all the students for their patronage.

Dr. McChesney: "Didn't you study your lesson for today, Mr. Currie?"

Currie: "No, sir."

Dr. McChesney: "Why not?"

Currie: "Cause it was raining last night."

INVESTMENT SERVICE

Turn Your Idle Dollars Into High Class Securities

Stocks! Bonds! Mortgages! We Buy Them, Sell or Trade. Get Our Prices for the Best Market

CARL E. SMITH

$331 \frac{1}{2}$ E. Main St., Xenia, Ohio Phone 1088

Farm Loans, Any Amount, 5\% Int. Local Preferred Stocks for Sale at Attractive Prices

\section{Moser's Shoe Store}

XENIA, OHIO

Best Shoes

Best Styles

We Specialize on Corrective Fitting

\section{Adair's}

FURNITURE

CARPETS

STOVES

VICTOR VICTROLAS

20-24 North Detroit Street

Xenia, Ohio

\section{Finney's Millinery Shop}

THE LATEST MILLINERY

AT THE BEST PRICES

6 West Main Street

Xenia, Ohio 


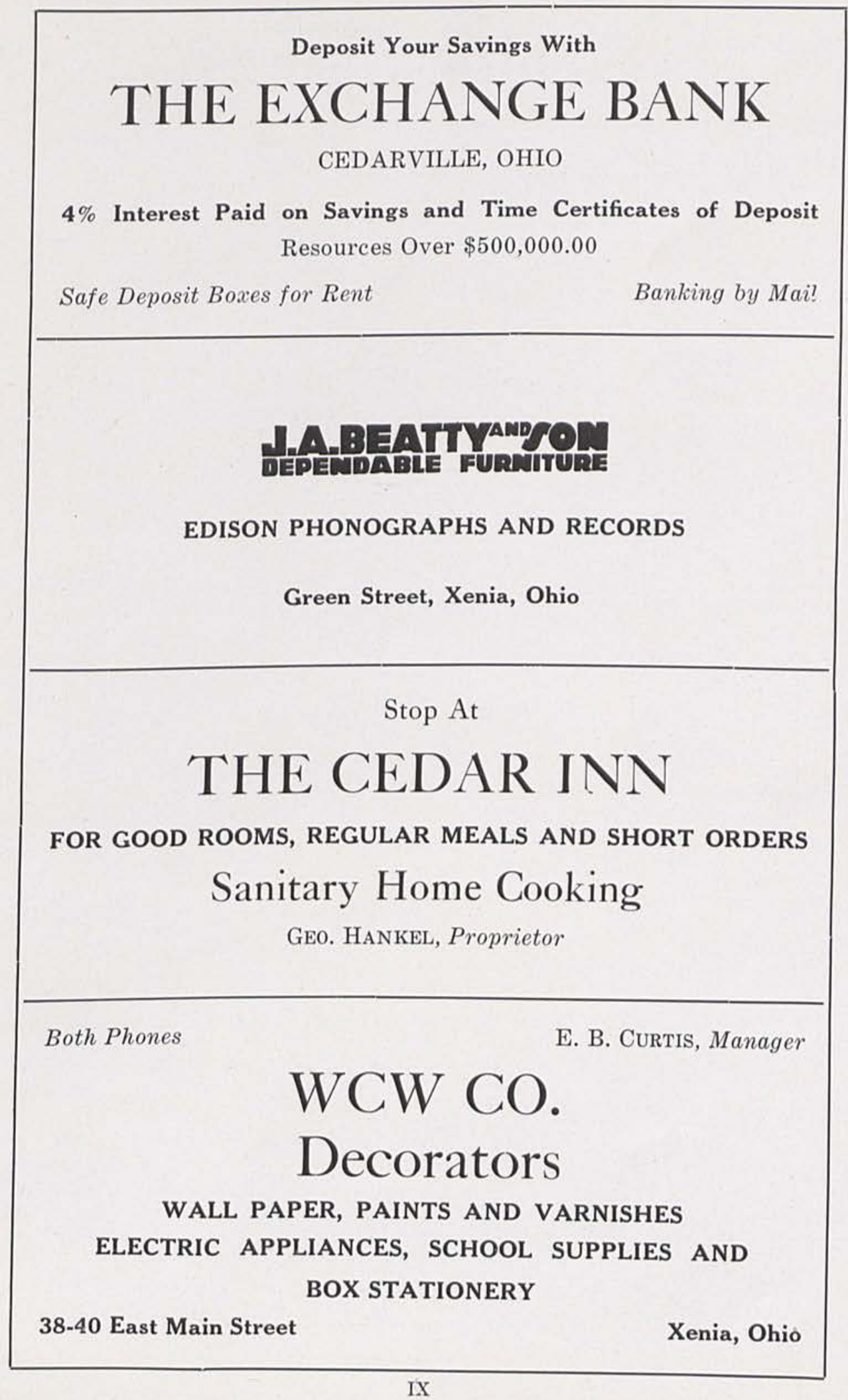



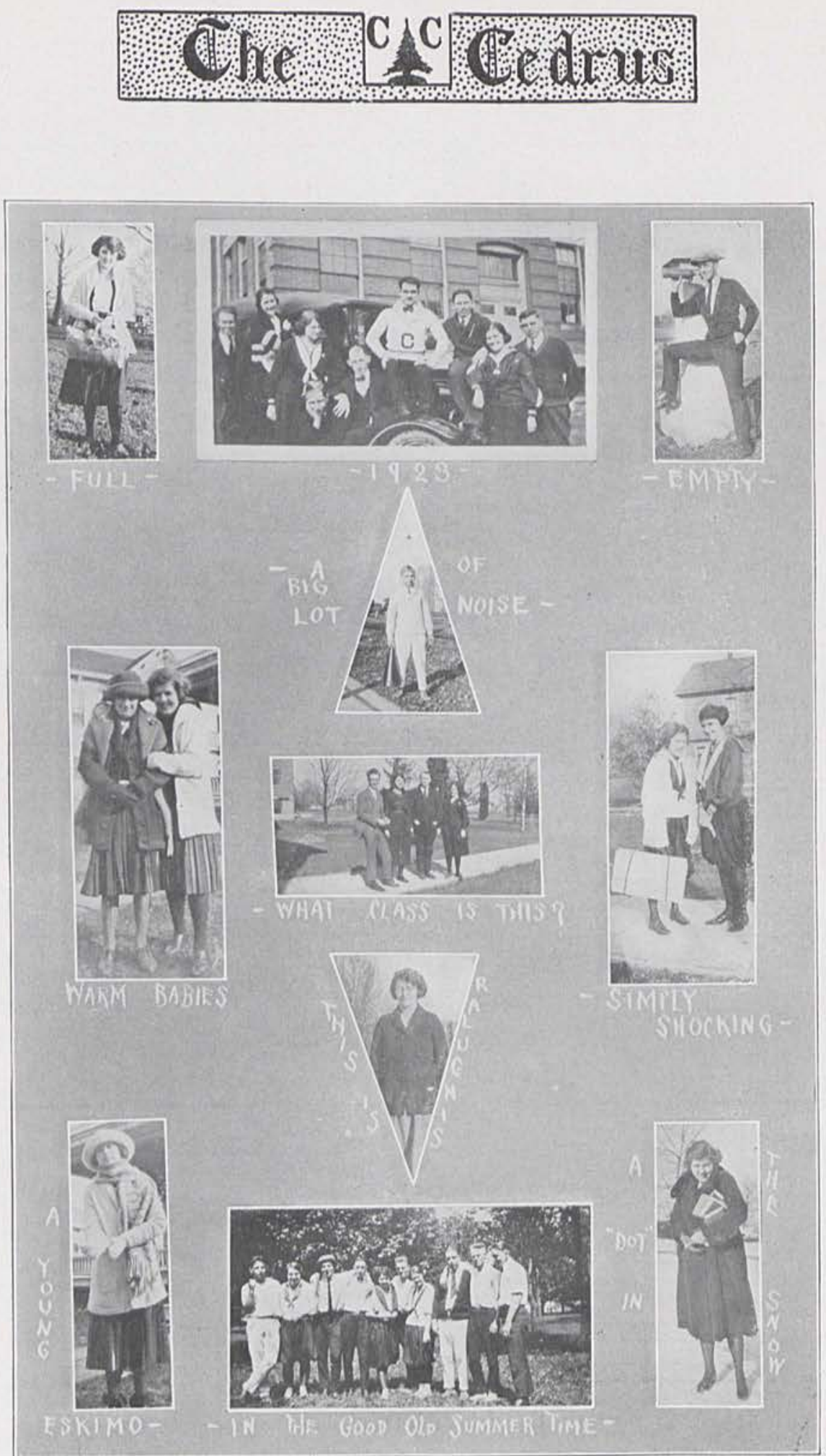


\section{SH-H-H-H-H-H-H \\ Don't Tell This To A Soul}

We are going to have a swell feed up in our room tonight. It is going to be some spread, chicken, oh boy, and Standard Package Ice Cream from Doc's.

Have you ever eaten Standard Package Ice Cream? It is packed in quart or pint cakes in a neat pasteboard package; just wrap it up, tuck it under your arm and take it home. It slices like cake, rich, cold, and good.

"GOODNESS,-How You'll Like It"

IT ARRIVES FRESH EVERY DAY FROM SPRINGFIELD

Richards Drug Store

"Popular With The Students" 
Our Meats am good and sweet,

Our Groceries they are fine,

That's why the Club trades here all the time.

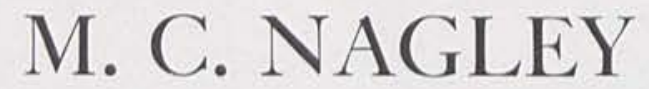

Grocery and Meat Market

Phone 40

We would like to ask the president of the Senior Class why he desires to wear a raincoat when taking charge of meetings.

Did you hear the racket when Jack Ewbank came down the aisle? Some candy-striped shirt!!!

- For -

Up-To-Date Jewelry, Expert Watch, Clock and Jewelry Repairing and

Properly Fitted Eye Glasses

$$
\begin{aligned}
& \text { L. A. WAGNER, O. D. } \\
& \text { Jeweler and Optometrist }
\end{aligned}
$$

Standard License

9 W. Main Street, Xenia, Ohio

Allen Building

\section{Wm. McCoy \& Son}

\section{Barber Shop}

\section{ALL WORK FIRST-CLASS}

Ladies' and Children's Work a

Specialty

Cedarville - - Ohio
Pure Oil and Gasoline

Batteries Recharged and Repaired

HARROW BATTERY \& TIRE SHOP

Firestone Tires and Tubes Studebaker-Wulff Tires and Tubes

Phone No. 3

Cedarville - - Ohio 
"Say It With Flowers"

\section{Anderson Flower Shop}

Flowers Telegraphed Anywhere

Member Florist Telegraph Delivery Association

Xenia, Ohio

Wilmington, Ohio

L. S. Barnes \& Co.

Wall Paper and Paints

DECORATORS

PICTURE FRAMING STATIONERY

Green Street

Xenia, Ohio

Phone 733

OFFICIAL

CLASS PHOTOGRAPHERS

"1923"

THE STANTON STUDIO

$26 \frac{1 / 2}{2}$ So, Fountain Ave., Springfield, Ohio 


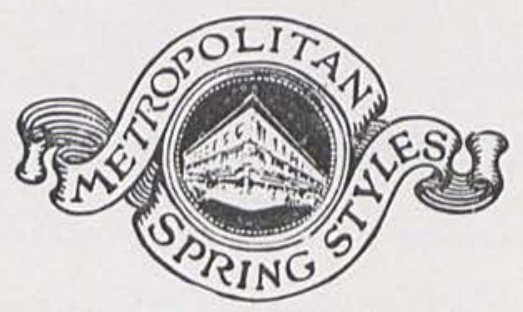

The new 1923 suits and topcoats tailored at Fashion Park and by The House of Kuppenheimer are

Ready for your inspection

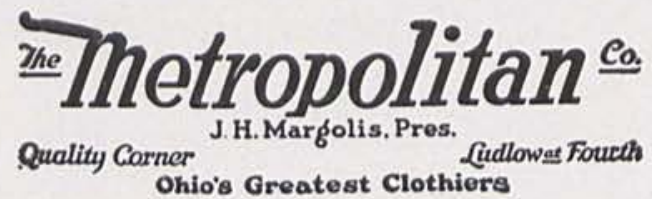

Dayton, Ohio

Pete: "Well, this isn't the first time I've washed dishes."

Ruth Mc.: "No, nor it won't be the last time."

Pete: "Oh, don't take too much for granted."

One of the girls: "What part of the New Testament shall we read for the next six weeks?"

Hazel Williams: "I know! Let's read Paul's letters."

If you want to be dressed right, you want your clothes made to order.

We do it for you and do it right.

$$
\begin{gathered}
\text { Kany } \\
\text { The Tailor }
\end{gathered}
$$

That IS ALL WE DO-

$\frac{1}{\div}$ EXAMINE EYES AND FURNISH GLASSES-

BUT WE DO IT RIGHT

$$
\text { Wilkin छे Wilkin }
$$

Opposite Court House Upstairs

Xenia, Ohio

26 So. Detroit St., Xenia, Ohio 

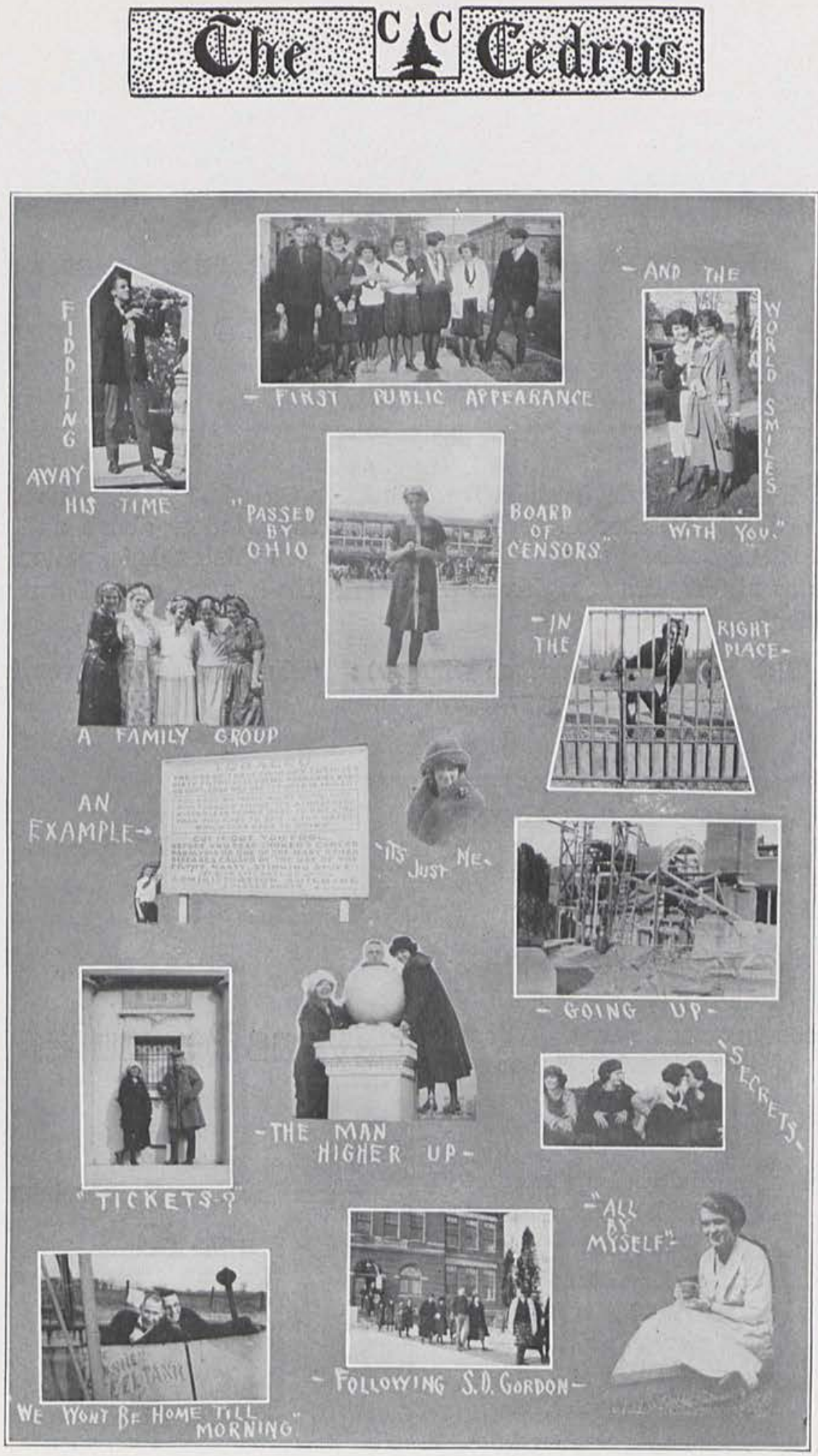


\section{AUTHENTIC SPRING STYLES}

Complete Showing of Suits and Top Coats-for Men and Young Men-Norfolks, Sport Models, Conservatives and

a New Four-Button Model

Come Up and Look'Em Over, Fellows

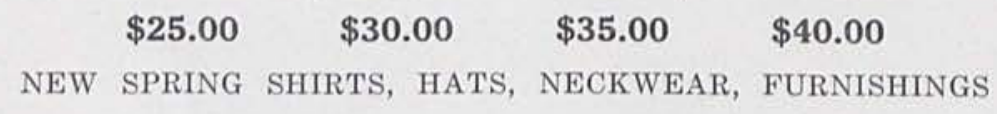

W. D. ALEXANDER \& CO. SPRINGFIELD, OHIO

Markle was playing a Victrola down on Oglesbee's porch one night when Mrs. Oglesbee's head appeared in the window above and her voice rang out in the night air: "What do you think this is, playing so late at night? The neighbors will think this is some sort of a rough house."

Dorothy, (from another window): "Shut up, mamma, or they will think you are the proprietor."

The "Sweetest" Spot in Xenia

Where the good "Goodies" Come from

The

\section{Xenia Candy Kitchen}

Headquarters for the Young Folks and Old Ones too

Delicious Specials from our Fountain

Wonderful Candies, Chocolates and Bon-Bons

LUNCH

Where the Business Men and Women

Come for Something Light, yet Hot, and Attractively Served

We try to Serve You with What You Want and at Popular Prices

Come and Visit Us
WHEN IN CEDARVILLE

Eat at

Evans Restaurant

Home Cooking; Soft Drinks and Ice Cream

We Strive to Please

XENIA AVE. 


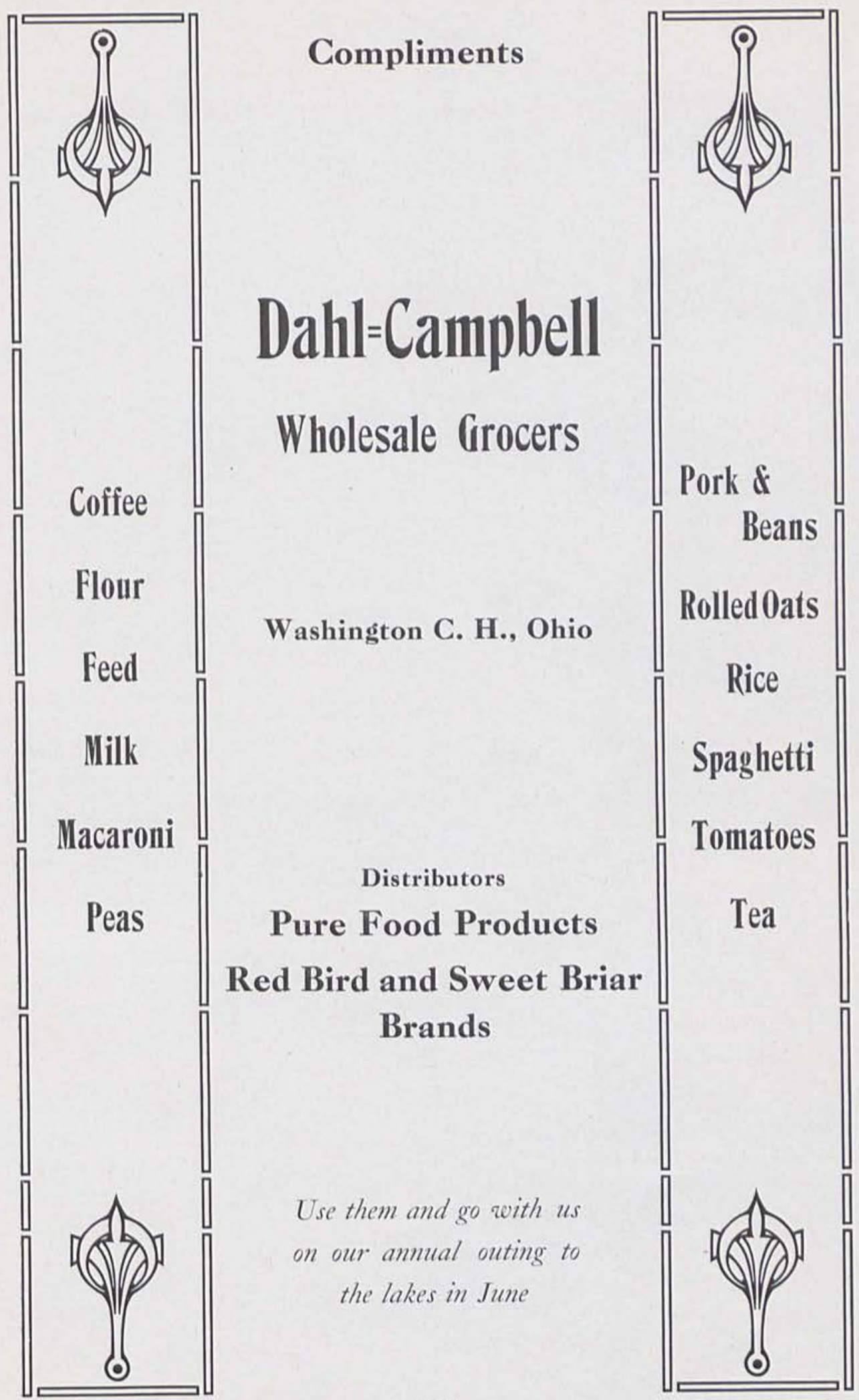




\section{The Hutchison Eै Gibney}

\section{Company}

XENIA - - OHIO

Springfield Tea Company

Springfield, Obio

ROASTERS OF FINE COFFEES

Give Us a Trial

WE ROAST IT-OTHERS PRAISE IT

\section{Eddie the Tailor}

"Service The Way You Like It"

CLEANING

PRESSING DYEING

REPAIRING

\section{SHOE SHINING}

Ladies Work a Specialty

2 Xenia Ave.

CEDARVILLE, OHIO
$10 \mathrm{~W}$. Washington St. SPRINGFIELD, OHIO 


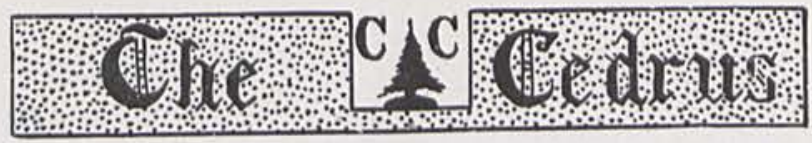

(Continued from page 92)

The Condemned Dormitory

beings as they crouched under his bed, anxiously awaiting the signal to arise.

They had not long to wait for suddenly two Devaline whistles in the mouths of two students, and a rotary fan in the hands of a third, gave forth the sound of a mighty onrush of wind. Seated in the window directly below the one in the room in which John was sleeping, another student sent frequent flashes from a powerful flashlight while another imitated loud peals of thunder by rumbling on a huge bass drum; a dozen windows rattled violently, and two boxes of bricks, one near each chimney, were heard rattling with a terrifying din down the old tin roof and falling on the pavement fifty feet below.

John awoke with a start; Jack had risen to his knees in the middle of the bed and was wildly shouting that a storm had come, and the house was falling down and for all to flee for safety. John tried vainly to spring from the bed, but Jack's knees were mysteriously planted on the twisted skirts of his night-gown, and he only floundered in his frantic efforts. The wind continued to howl and screech; the lightning and thunder came at more frequent intervals; the bricks continued to fall; a spray of water from the long college hose began to gush intermittently against the window, sending, through the narrow opening at the top, an icy spray into the very face of the terrified lad. To the fearful rattling of the windows was added the occasional sound of breaking glass. Suddenly the bed rose high on one side and began to slide across the room as if the floor at one side had suddenly sunk several feet. At last John managed to tumble from the bed and make a wild rush for the door, that led into the hall. The hall was dark and in his rush for the stairs he smashed into a door that stood half open; he stood dazed for a moment; a fierce gust at the west end of the hall sent a pane of glass crashing to the floor; a flash of lightning showed him the location of the stairs and he made a wild rush down the perilous flight. A box of bricks followed close on his heels and seemed to stimulate him to greater action; a board placed with one end between two beams and the other in the strong hands of a student, gave forth a cracking, splintering sound, as if the lower stair-way were being crushed between heavy falling walls. Another flash of light, fortunately, showed him that, at least the top of the stairs still existed and also the exact place of its location. He quickly made, what he thought to be, the fatal plunge; another box of bricks followed closely after his flying feet. Before he reached the outside door it blew violently open and, insanely terrified, he rushed wildly out into the stormy night and fled frantically across the campus into the shelter of a grove of trees, while a down-pour of water from the well-aimed hose thoroughly drenched his scanty attire. He clutched fitfully at the trunk of a slender tree in order to keep from sinking helplessly to the ground, for with the feeling of safety came also the feeling of weakness.

The sudden stop brought back some of his senses; he looked back to see if the building was entirely wrecked and if any of the other boys had escaped. He stood bewildered; for he heard not a sound and the condemned old dormitory stood motionless in the clear cool night, looking peacefully down upon him; he looked up at the sky and scanned the heavens vainly for signs of the recent storm; not a breath of wind stirred; his gown was fluttering violently, to be sure, but it seemed to be the effect of the rapid motion of his knees from within, rather than from any external source. He heard a smothered laugh quickly followed by another; he began to come to his senses. Suddenly the laughter of fifty boys broke upon the still night air. To John's active mind the whole situation was revealed as by a flash of light.

John tried to flee, but fell exhausted; a sense of shame mingled with pride brought back the color to his face and control to his voice, as fifty boys gathered around him and filled the night with deafening peals of laughter. "Well, this is a queer time of night to see you about it," spoke John stoutly, addressing the student manager of the dormitory, "but for the remainder of the four years, that I shall remain at Thurston College, I wish to engage that north-west corner room on the third floor."

Del Wickerham. 
"Get a policy, and then hold on to it. It means self-respect; it means that nobody will have to put something in a hat for you or your dependent ones if you should be snatched away from them."

-Grover Cleveland.

\section{MAKE AN APPOINTMENT WITH \\ W. L. CLEMANS, Agent MUTUAL LIFE OF NEW YORK}

Fraser: "Bowyer talked in his sleep the other day."

Student: "How's that?"

Fraser: "He recited in Chemistry."

Dick Elder: "Will you give me something for my head?"

Earle Collins: "I wouldn't accept it for a Christmas present."

M. Stormont: "Where do they do electroplating?"

D. White: "In a jewelry store."

\section{KUPPENHEIMER \\ GOOD CLO'THES \\ SURE - - FIT - - CAPS \\ That Adjustable Kind}

VAN HEUSEN GOLLARS

Katz है Richards

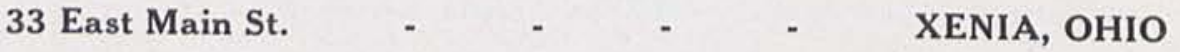

\section{Interurban Restaurant}

"At The Station"

When You Visit Xenia there is

Only One Place to Eat

Where You Get Real Food and Service too

Open Day and Night

Dontchos Bros., Props.

\section{BUS Leaves CEDARVILLE at}

9:00 A. M.

2:00 P. M.

5:00 P. M.

BUS Leaves XENIA at

11:00 A. M.

4:00 P. M.

6:00 P. M.

Phone 3-209 
The

HAGAR STRAW BOARD

\& PAPER COMPANY

Cedarville, Ohio

Fine Straw Board for Corrugating 

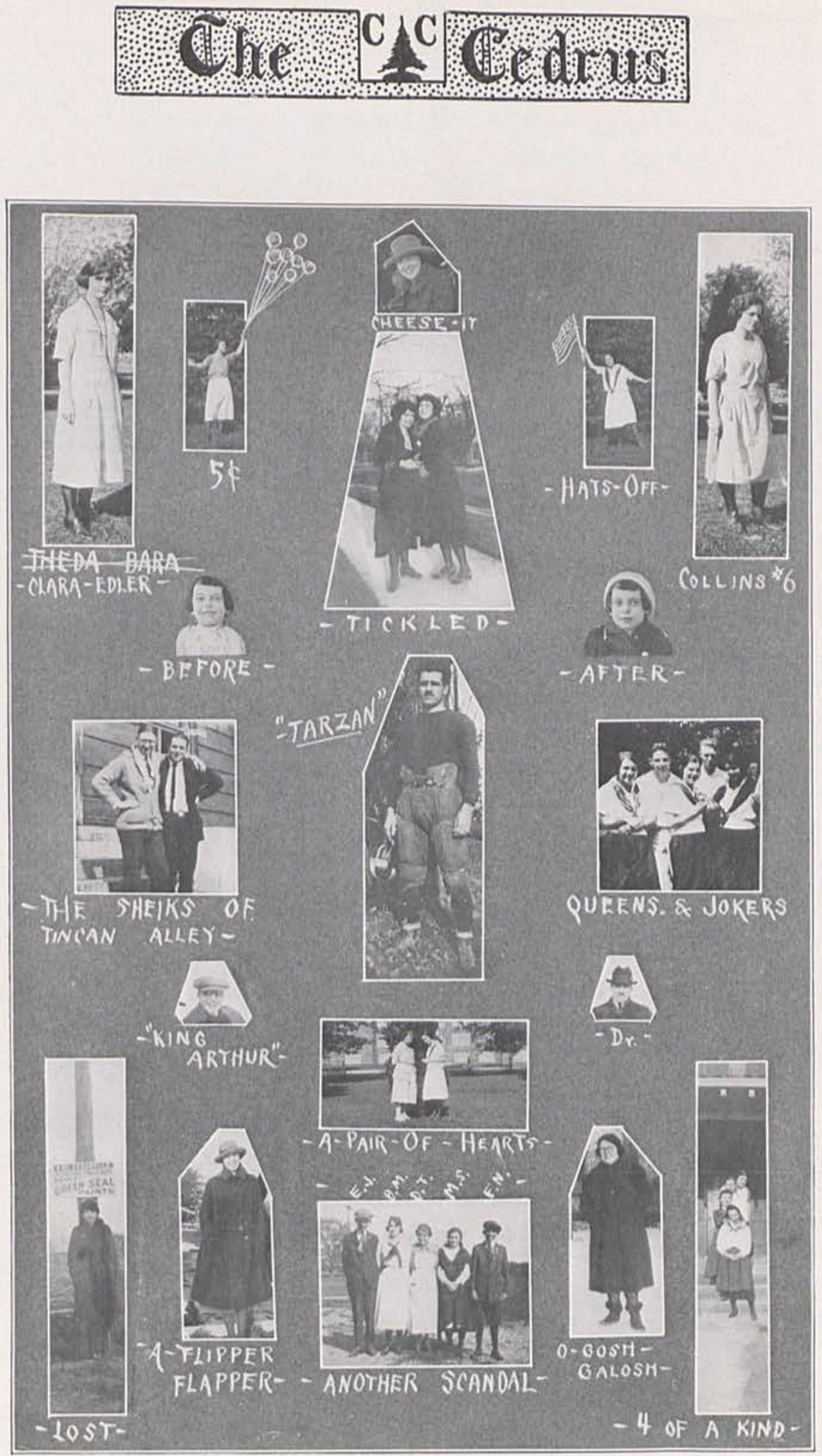
Phone 2-87

\section{R. H. Dines, D. D. S.}

Office Hours : $8-12$ and $1-5: 30$

Other Hours by Appointment Only

If You Want a Hat Becoming To You

You Want To Be Coming To Us

\section{(1) sterly Allillinery}

37 Green St.,

XENIA
OHIO

\section{FOR TAXI SERVICE}

Call No. 3

Calls Answered Day or Night

CEDARVILLE, OHIO

Markle (admiring Lucile Johnson's diamond ring): "You know I have a half interest in a ring like that back in Pennsylvania."

Lucile: "Seems to me it is a pretty half-hearted interest."

Miss Brand: "What is the difference between, 'I will hire a taxi,' and, 'I have hired a taxi?',"

Orville Walker: "About six dollars and a half."

Johnny Davis was asked if he ever tried the "Why Dance" with Bee. He answered, that he didn't need that for an excuse.

\section{THE CEDARVILLE FARMERS' GRAIN CO.}

GRAIN, SEEDS, FEED, COAL, HARDWARE, IMPLEMENTS HEIDER TRACTORS

You Are Just As Near To Us As Your Telephone

Phone 21

XXIII 


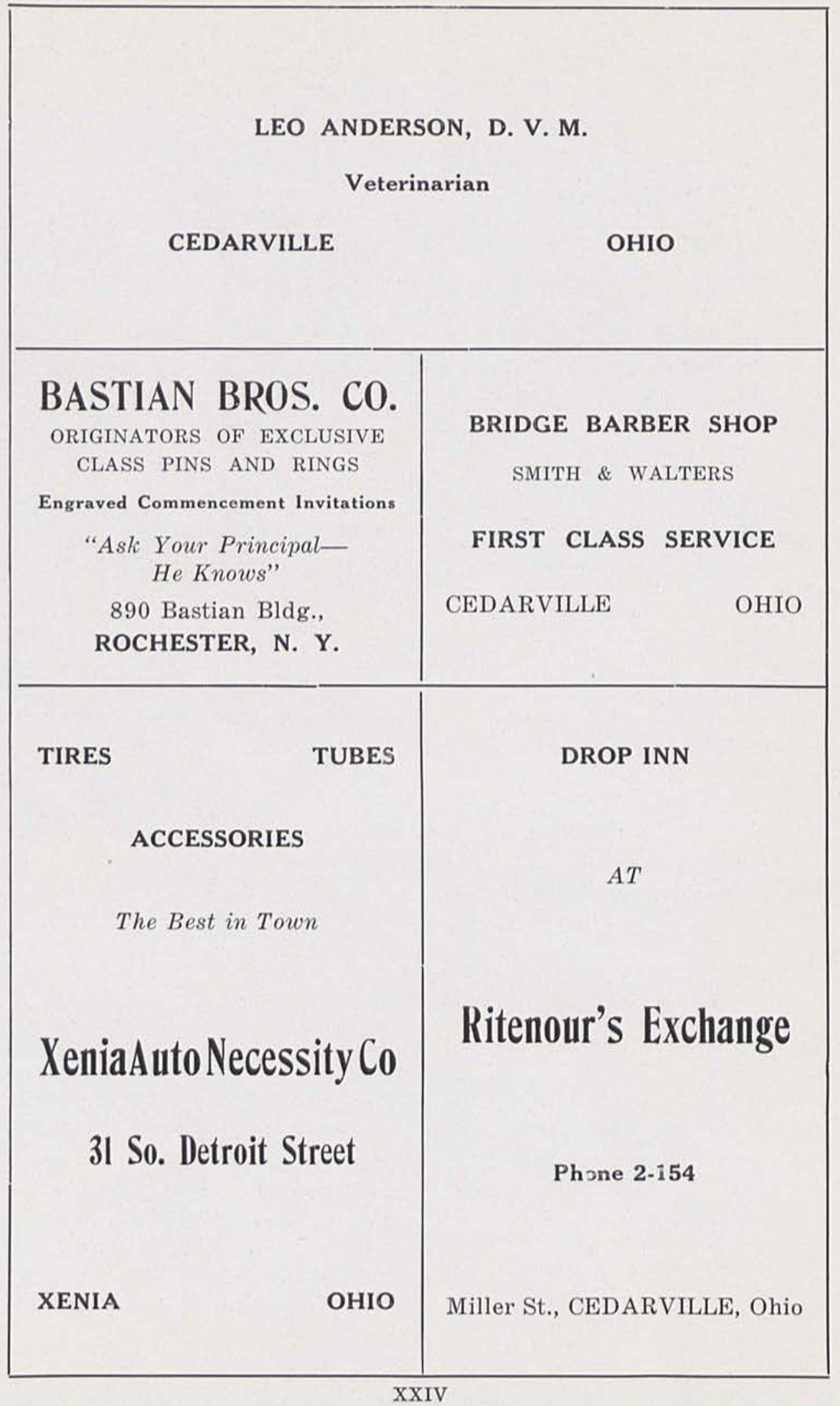



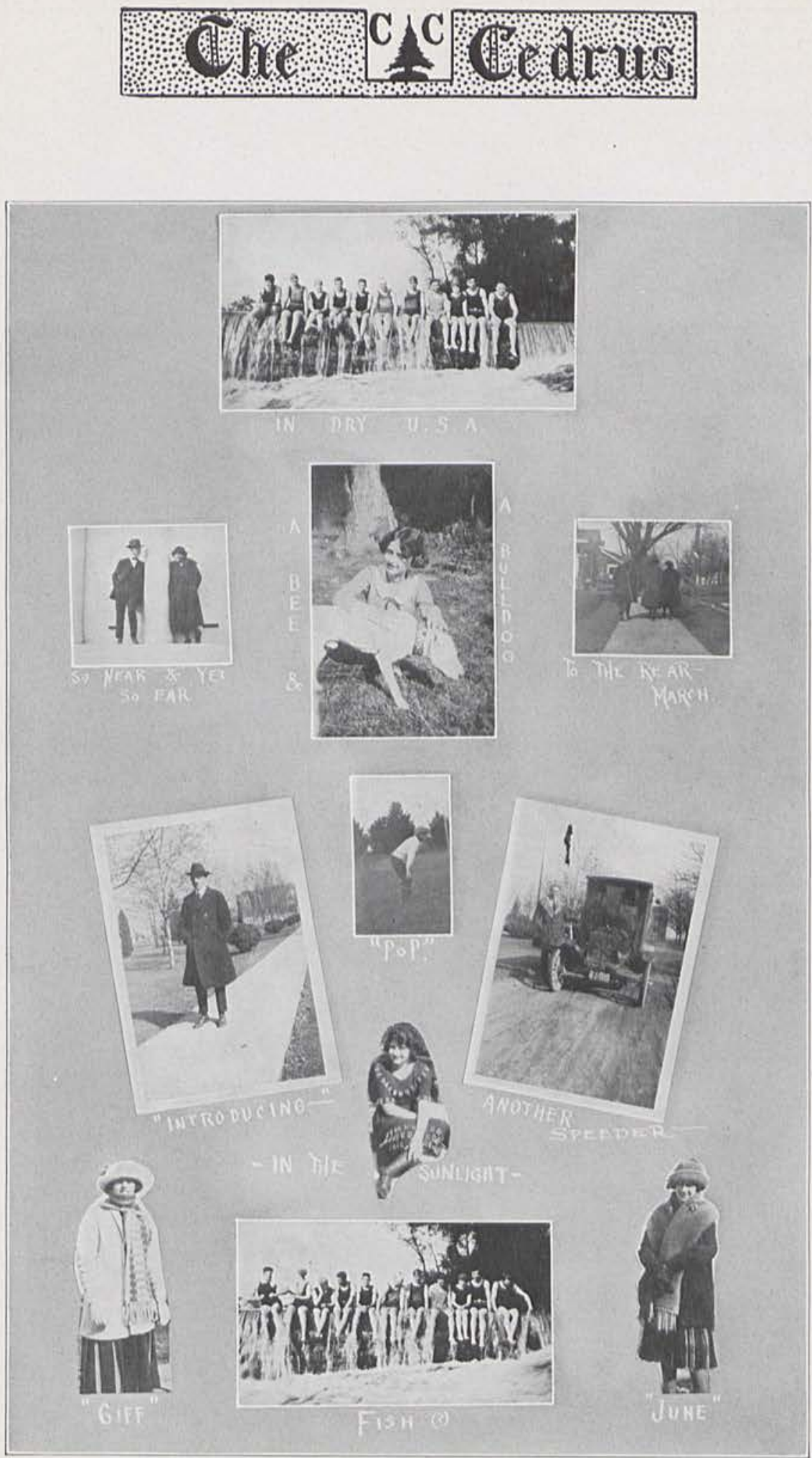


\title{
Cedarville Lumber Co.
}

\author{
Everything In
}

LUMBER, MILL WORK, BUILDING MATERIAL, FENCE AND POSTS

Phone 33

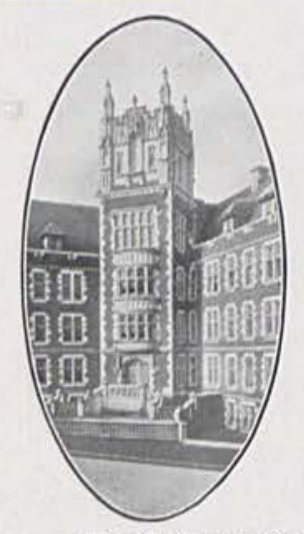

\section{The Western Theological Seminary}

Pittsburgh, Pa.

A Seminary for College Graduates

A complete modern theological curriculum, with elective courses leading to the degree of B.D. Graduate courses of the University of Pittsburgh, leading to degrees of A.M. and Ph.D., are open to properly qualified students of the Seminary. Two entrance prizes of $\$ 150$ each and a post-graduate fellowship of $\$ 500$. Exceptional library facilities. A new dormitory equipped with latest modern improvements. Social hall, gymnasium, and students' commons. Ninety-sixth year begins September $18,1923$.

For Information apply to President James A. Kelso, Ph.D., D.D., LL.D.

Student on arriving in Cedarville: "What are your terms for students?"

Landlady: "Dead-beats and bums."

Miss Brand, at close of Browning class: "For the next recitation you may complete 'Rabbi Ben Ezra' and then we will go on to 'A Death in the Desert!" "

"Professor Fraser, what do you think of the Cedrus jokes?"

Fraser: "They demonstrate clearly that ontogeny recapitulates philogeny."

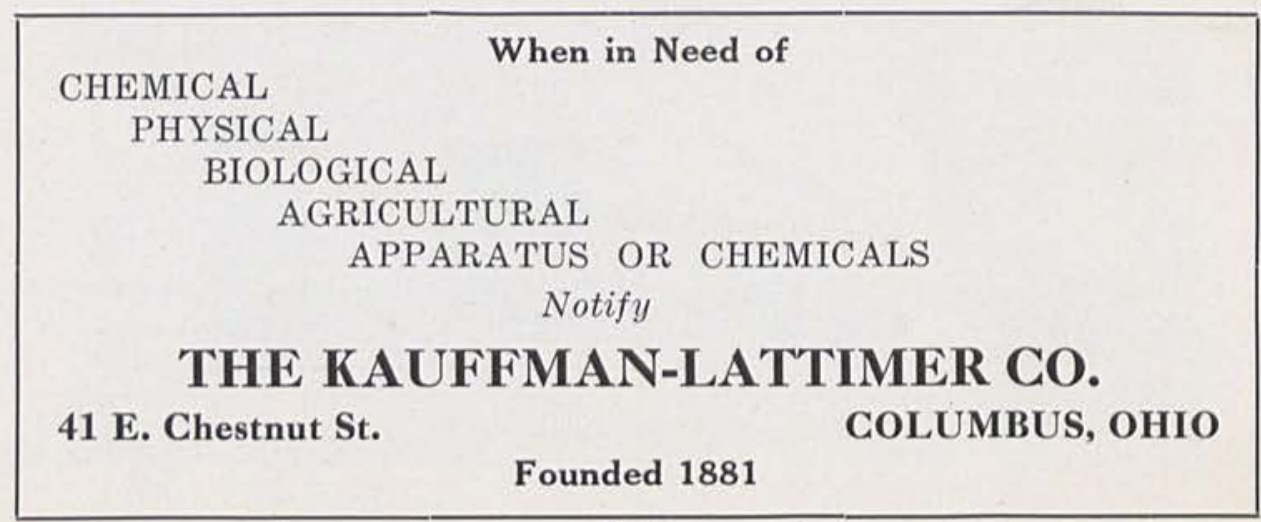




\section{The Cedarville Herald}

COMMERCIAL

CATALOGUE

JOB PRINTING

Let Us Give You An Estimate On Your Printing

\section{Kaiser Laundry \\ XENIA, OHIO}

Send Your Laundry to Us and

We Will Return You Bundles of Happiness

A. E. RichaRds, Agent

Bell 316 - $\quad$ - Phones - $\quad$ - $\quad$ Citz. 230

TEACH YOUR DOLLARS TO

HAVE MORE CENTS

AT

Troute’s

Cash and Carry Grocery

CEDARVILLE - - - OHIO

Ray (after Junior play): "Marion I was surely glad Lucille kissed you."

Marion: "So was I, kid."

"Jack, have you got a date for the tournament?"

Jack: "No, do you think I would spend a dollar on a girl for nothing."

We all wonder why Ray left Kyle's party at ten o'clock, saying he must be home at once. Is it getting so bad that he calls Smith's home?

Flossie says she thinks it was a pretty cute idea. 


\title{
C. E. Masters Groceryman
}

EXCHANGE BANK BUILDING

Phone 2-44

CEDARVILLE, OHIO

Mother: "Florence, you might as well give that tall, young man who comes to see you in the evening a message."

Florence (blushing): "Yes, mother."

Mother: "Tell him we have no objection to his running up the gas bills but we wish he wouldn't carry away the morning paper when he leaves."

Father: "Howard, I am afraid I'll not see you in heaven."

Howard: "Why, what have you been doing now, Pop?"

\section{DAYTON AND XENIA BUS LINE}

\author{
Bus Leaves XENIA STATION at No. 8 East Market Street
}

A.M. A.M. A.M. A.M. A.M. A.M, A.M. P.M. P.M. P.M. P.M. P.M. P.M. P.M.

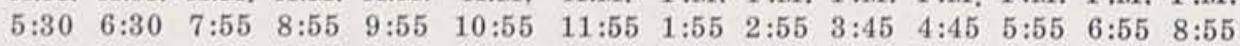

FARE IS 30 CENTS ONE WAY

Bus Leaves DAYTON STATION at No, 119 West Fourth Street

A.M. A.M. A.M. A.M. A.M. A.M. A,M. P.M. P.M. P.M. P.M. P.M. P.M. P.M. P.M.

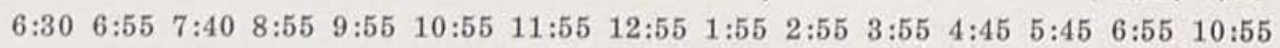

ROUND TRIP FARE 50 CENTS

Dot O.: "You remind me of Venus de Milo."

Earle C.: "But I have arms-",

Dot: "Oh, have you?"

Wick: "Bill, who do you think is doing the most good, Henry Ford or Billy Sunday?"

Bill A.: "That's easy. Henry Ford!"

Wick: "How's that?"

Bill: "He has shaken the devil out of more people than Billy Sunday ever can." 


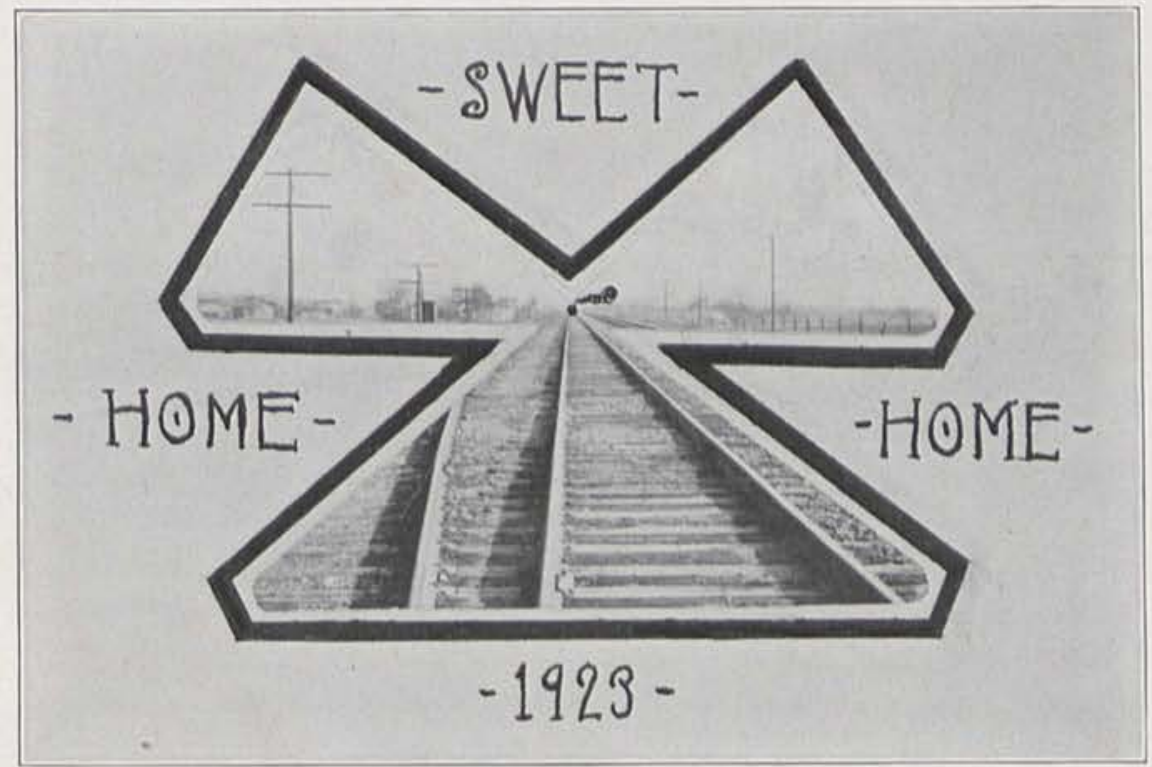

14

if 

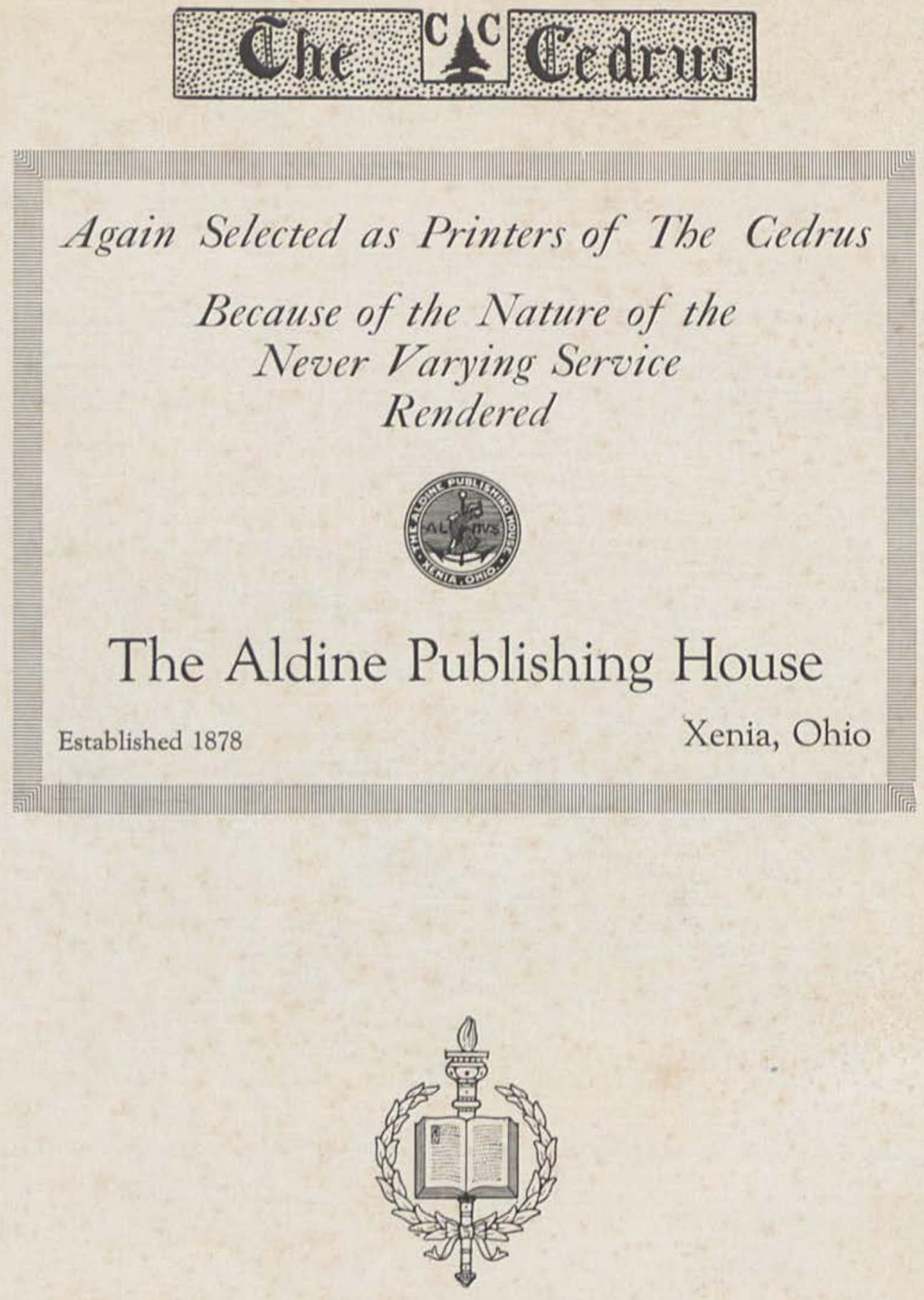

